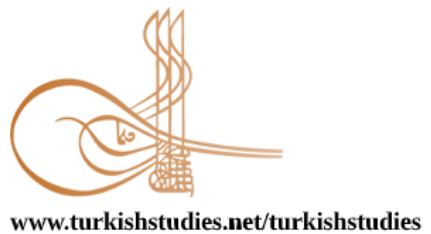

Turkish Studies

www.turkishstudies.net/turkishstudies

eISSN: $1308-2140$

TERNATIONAL

BALKAN

Sponsored by IBU

Research Article / Araştırma Makalesi

\title{
COVID-19 Sürecinde Online Seslifoto (OSF) Yöntemiyle Biyopsikososyal Manevi ve Ekonomik Meseleleri ve Genel İyi Oluş Düzeyini Ele Almak: OSF'nin Türkçeye Uyarlanması
}

\author{
Utilizing Online Photovoice (OPV) Methodology to Address Biopsychosocial Spiritual Economic \\ Issues and Wellbeing during COVID-19: Adapting OPV to Turkish
}

\begin{abstract}
Ahmet Tanhan*
Abstract: In this study, the researcher focused on four main goals: (1) understanding the most important biopsychosocial spiritual and economic facilitators and barriers of college students during COVID-19 from their own unique perspective utilizing Online Photovoice (OPV); (2) advocating with the volunteer participants and partners to convey the results in all possible ways, especially through online avenues due to the pandemic process, to the key people and institutions in order to enhance the facilitators and address the barriers; (3) examining participants' attribution of facilitators and barriers based on Ecological Systems Theory (EST) levels; and finally, (4) adapting and utilizing OPV in Turkish in a way so that it can be fully functional as it is used in its original English version. In this study, the researcher utilized the adapted Turkish version of OPV to collect data. He then utilized Online Interpretative Phenomenological Analysis (OIPA) with some slight changes to analyze the data. The theoretical framework of the research consisted of Community-Based Participatory Research (CBPR) grounded in EST. In total, 148 college students fully participated and 127 consented for the research. The whole research was conducted online. Nineteen main facilitator-related themes emerged, and the three most expressed were being mindful or present at the moment (32\%), having family or friends (18\%), and practicing spiritual activities (18\%). Twenty-one main barrier-related themes emerged, and the three most reported barriers were not being able to physically spend time with loved ones $(26 \%)$, psychological issues (21\%), and online/distant education (21\%). Participants attributed the facilitator and barriers to EST levels respectively as follows: individual/intrapsychic factors $(86 \% ; 76 \%)$, microsystem (10\%; $71 \%)$, exosystem $(46 \% ; 58 \%)$, and macrosystem $(35 \% ; 48 \%)$. The researcher provided practical implications in four areas: Research, social services (e.g., health, mental health, local and general administration), education, and advocacy from a holistic biopsychosocial, spiritual, economic, and contextual perspective. Results of the study as well as ongoing advocacy efforts indicate that adapted OPV with the theoretical framework selected
\end{abstract}

\footnotetext{
* PhD, Ekonomik ve Sosyal Araştırmalar Merkezi- ESAM (Ankara, Türkiye), Kuzey Karolayna Devlet Üniversitesi (Kuzey Karolayna, ABD), Müslüman Ruh Sağlığı Enstitüsü (Michigan, ABD), Adiyaman Üniversitesi (Adiyaman, Türkiye), Dr. Öğretim Üyesi, Psikolojik Danışmanlık ve Rehberlik Ana Bilim Dalı.

PhD, Economic and Social Research Center - ESAM (Ankara, Turkey), The University of North Carolina at Greensboro (North Carolina, USA), Institute for Muslim Mental Health (Michigan, USA), Adiyaman University (Adiyaman, Turkey). Department of Counseling.

ORCID 0000-0002-4972-8591

tanhanahmet3@gmail.com

Cite as/ Atıf: Tanhan, A. (2020). COVID-19 sürecinde online seslifoto (OSF) yöntemiyle biyopsikososyal manevi ve ekonomik meseleleri ve genel iyi oluş düzeyini ele almak: OSF'nin Türkçeye uyarlanması. [Utilizing online photovoice (OPV) methodology to address biopsychosocial spiritual economic issues and wellbeing during COVID-19: Adapting OPV to Turkish.] Turkish Studies, 15(4), 1029-1086. https://dx.doi.org/10.7827/TurkishStudies.44451

Received/Geliş: 23 June/Haziran 2020

Accepted/Kabul: 10 August/Ağustos 2020

Copyright $(\mathrm{C}$ MDE, Turkey

Checked by plagiarism software

Published/Yayın: 30 August/Ağustos 2020

CC BY-NC 4.0
} 
can be effectively utilized to examine and address biopsychosocial, spiritual, economic, and other contextual issues at the individual, group, and/or community levels. OPV seems much more effective especially during difficult times (e.g., pandemic, endemic, conflicts, lack of safety,) when it is relatively a lot more difficult to be outdoors and interact socially with other people. OPV also provides several crucial advantages including reaching out to many underprivileged and disempowered diverse groups. OPV also protects anonymity while also allowing volunteer participants to voice their experiences accessible to others and as a result, be able to advocate publicly for improving wellbeing and address issues from a biopsychosocial spiritual and economic perspective. The researcher obtained an institutional review board approval for this study.

Structured Abstract: COVID-19 has caused many unprecedented biopsychosocial spiritual and economic issues across the world (Otanga et al., 2020) including Turkey while affecting much more people with less privileges or those dependent on others (Arslan et al., 2020; Çiçek et al., 2020; Genç et al., 2020a; Haktanir et al., 2020; Sever \& Özdemir, 2020; Tanhan et al., 2020). These researchers called for more robust and specific research for specific populations.

\section{Biopsychosocial Spiritual and Economic Issues During COVID-19 in Turkey}

Researchers generally found that college students in Turkey face many biopsychosocial spiritual and economic issues while utilizing resources for developing psychological resilience (Kızıldağ et al., 2012; Tanhan et al., 2020; Uğur et al., 2020). Some researchers specifically focused on COVID-19 pandemic and college students in Turkey and called for using Online Photovoice (OPV), an innovative and an entertaining well-grounded research method to understand facilitator factors, i.e. supports or strengths as well as risk factors or barriers, i.e., concerns or issues in the context of the pandemic and Ecological Systems Theory (EST)Tanhan et al., 2020). Tanhan and Strack (2020) recommended using OPV when it is relatively difficult or impossible to meet face-to-face. Other researchers also called for adapting OPV (Tanhan \& Strack, 2020; Tanhan et al., 2020) or traditional photovoice (Delgado \& Wester, 2020; Goodhart et al., 2006; Sever \& Özdemir, 2020; Tanhan \& Francisco, 2019; Wang \& Burris, 1997; Warne et al., 2013; Yilmazli Trout et al., 2019) from a contextual perspective to study for more effective research and services. There is a lack of wellgrounded and innovative research, especially for qualitative studies. Based on his extended literature review of COVID-19 and OPV, the researcher did not find any researchers who have used OPV or traditional photovoice to understand how people have been going through COVID-19 pandemic. Also, to the best knowledge of the present researcher, no other researchers have adapted OPV in Turkish language, which was an important gap and previous researchers also mentioned it (Tanhan et al., 2020). These are some important gaps. Based on the findings of the present study, OPV seems to be an effective and innovative method to employ for empowering individuals and communities to enhance their wellbeing and address biopsychosocial, spiritual, and economic issues through advocacy and collaboration with individuals, communities, and key people and institutions. It also helps individuals and communities express their needs, perspectives, and be part of addressing biopsychosocial spiritual and economic wellbeing and issues.

\section{Purpose and Significance of the Study}

In this study, the researcher aimed for four main goals: (1) Examining the most important biopsychosocial spiritual and economic facilitators and barriers during COVID-19 for college students from their own unique perspective utilizing OPV; (2) advocating with the volunteer participants and partners to convey the findings in all possible ways, especially through online avenues due to the pandemic process, to the key people and institutions in order to enhance the facilitators (supports, strengths) and address the barriers (concerns, issues) that are expressed by study participants; (3) exploring how participants attribute the facilitators and barriers to which EST levels; (4) and finally, adapting and utilizing OPV in Turkish language to evaluate if it is just as effective as it has been in its use in the original English version.

\section{Theoretical Framework}

The theoretical framework of the research consisted of utilizing adapted Turkish version of OPV with Community-Based Participatory Research (CBPR) grounded in EST. Tanhan et al. (2020) also suggested similar comprehensive and contextual theoretical frameworks for working with communities especially during difficult times (e.g., pandemics, conflicts, natural disasters). Different researchers use different concepts including Community-Based Participatory Action Research- CBPAR (Maiter et al., 2008); Community-Based Participatory Research- CBPR (Tanhan et al., 2020), Participatory Action Research- PAR (Christensen et al., 2018; Minkler, 2000); school-community partnership (Doğan \& Julian, 2019); and ally development (Tanhan

Turkish Studies, 15(4) 
\& Francisco, 2020; Tanhan \& Strack, 2020) to explain and stress the importance of working with and for communities. All these concepts mean the same thing with some minor differences. The present researcher used the CBPR to shape the framework for this current study. In this study, the researcher adapted and utilized Turkish OPV version as the data collection method. He then utilized Online Interpretative Phenomenological Analysis (OIPA) to analyze data. The partners from CBPR perspective contributed to and shaped the research throughout, from the beginning of the research to date, engendering active social advocacy as one of the most important process of OPV.

\section{Method}

The researcher first conducted a comprehensive literature review of (a) OPV in Turkish to be sure if someone had already adapted or conducted similar studies and (b) empirical research on college students during COVID-19. He did these to ground the theoretical framework and move forward. The researcher followed the theoretical framework constantly to shape the following research processes: naming OPV in Turkish as OSF (Online Seslifoto), naming SHOWED acronym in Turkish as GÖZSAN, and collaborating with the volunteer participants and/or individuals interested in the research and especially for active social advocacy process. This comprehensive and functional theoretical framework was necessary because of its helpfulness in understanding and addressing facilitators and barriers at all levels of EST simultaneously, supporting advocacy for addressing issues and wellbeing for all starting with participants (Tanhan, 2019).

\section{Participants}

In total, 148 college students from a state university in the east of Turkey thoroughly completed all the questions in this study. However, only 127 of these participants consented to the research. The ones who consented were from 10 different schools under the university; e.g., pharmacy; education, engineering, medicine, seminary, agriculture, art, economics and administrative sciences, nursing, and architecture. Demographically, 56 out of 127 were men, 70 were women, and one person preferred not to indicate their sex. At the time of participation in the study, most of the participants $(n=75)$ reported living in a house/apartment with a garden during the COVID-19 pandemic, and 57 reported living in a house/apartment without a garden. The participants were able to choose both of the options.

The responses of participants regarding their socioeconomic status are as follows: 35 low, 82 middle, and 10 as high. In terms of marital status, 115 reported being single and 12 being married. The researcher used convenience sampling, a non-probability sampling technique, which is very effective for pilot studies. He sent the research participation link through a mental health clinic where he leads mental health research and services. The clinic serves all individuals, especially students, affiliated with the college. The researcher reminded people that the study was a pilot study to adapt OPV in Turkish language in order to understand how the adapted OPV version can be utilized during the COVID-19 pandemic. Therefore, he asked people not to share the research link with any other individuals. More than 500 people viewed the link. The researcher conducted the whole research study online.

\section{Procedure}

The researcher conducted a comprehensive literature review on OPV in Turkish and well-being of college students during the pandemic. Based on the existing and yet limited literature review, the researcher completed Institutional Review Board (IRB) forms and obtained IRB approval for the study. He designed the study with other researchers and students as the initial partners, who already had some issues and reported to the researcher owing to his lead at the mental health clinic for research and services at the university. Based on all these, the researcher collaborated with these initial partners and put the theoretical framework together. He translated the name of OPV to Turkish and came with many different names and translated SHOWED questions into Turkish. The researcher consulted with the partners which names and acronyms make much more sense for them. Based on all the interaction with the partners, the researcher and the partners chose OSF (meaning Online Seslifoto) acronym in Turkish to stand for OPV and GÖZSAN acronym in Turkish to stand for SHOWED among all other options. The researcher then checked with ten more researchers from different majors (e.g., counseling, psychology, finance, medicine) who knew Turkish and scientific research well to reflect on the acronyms and the explanation for what made the researcher and partners choose these ones. All the ten researchers agreed on the acronyms among all the other options. These researchers recommended some minor suggestions for the theoretical framework of the study. After all these, the researcher and the partners announced the study on individual online platforms to reach out to potential participants utilizing the services 
provided at the clinic. Several other college students and academicians also became partners following the announcement and during the study.

\section{Data Collection Instruments}

The researcher provided an online form that included a few sociodemographic questions. The form also included a video, an audio recording in M4A format, and a written document. The video, audio, and written documents included the same information on OPV and how to use it to participate in the study. All the information was on the adapted Turkish version of OPV. Different documents were provided to facilitate participation considering the pandemic context. The following links include visual, audio or written documents that facilitated participants' understanding of OPV and how to participate. Researchers or OPV event organizers may find the documents useful to utilize them in their future research. Researchers and participants with limited internet resources or data storage can benefit from the audio or written documents more than the video.

The readers, researchers, and all others who are interested can view OPV videos through the following links https://www.youtube.com/watch?v=ArqgA33EMDQ (English OPV video version) and https://www.youtube.com/watch?v=_eOimJTtC_Y (Turkish OPV video version).

The readers, researchers, and all others who are interested in the OPV audio and written documents can access through the following links https:/drive.google.com/drive/folders/1wtq6s4KU6zHR2uHU7ww9HJweYY_B3UiQ?usp=sharing (English version) and https://drive.google.com/drive/folders/1EDjhalb5gy_iJJXMahLR1Ye9qe1OiVy7?usp=sharing (Turkish version).

Additionally, the researcher found and provided a Facebook group and a Facebook page link for the current and future OPV research or activities so that participants, researchers and/or any other individuals who are interested in the topic and/or the results can interact with one another utilizing the group for more critical and meaningful conversations: https://www.facebook.com/groups/OPV.OSF.Online.Photovoice.Seslifoto (Facebook group) and https://www.facebook.com/OnlinePhotovoiceOPV (Facebook page).

\section{Study Steps}

The researcher introduced five steps to make participation easy, effective, and fun as much as possible. Through these steps, participants were able to move forward easily and more mindfully.

Step 1. Identifying the most important facilitator (support, strength) and barrier (concern, issue). Participants reflected on all possible facilitator and concern factors during their COVID-19 process and then identified the most important facilitator and barrier among all other possible factors.

Step 2. Taking photos of the most important facilitator and barrier. Participants took many photos that represent the most important facilitator. Participants were guided that they could take as many photos as they want and yet they could upload only one photo for the facilitator and one photo for the barrier. Participants were guided to choose which photo is the most representative based on their own perception and decision rather than perception of others. Additionally, photos do not have to explicitly represent the factors. For example, a photo of a tree can be the most representative for a participant to explain online education while a photo of a computer can be the most representative for online education.

In OPV, the researcher through the documents (e.g., video, audio) explained how participants can enhance meaning of their participation, stories, and photos if they participate actively in each step including taking time to take photos and upload the most representative one. However, OPV also allows participants using photos or drawings available for public and with no reserved rights or copies. That means they are allowed, though not recommended, to use any photos that are available online for public with no copyrights. This has been an important point in both Tanhan and Strack's (2020) and the current research because some participants do not have privileges of having a camera and some researchers are not able to provide such tools due to different reasons, e.g., not being able to get out and reach out to participants, lack of financial resources for research. And from an OPV perspective, it is important to act from a contextual perspective and strive as much as possible to include participants with fewer privileges rather than acting from an acontextual perspective and running the risk of silencing participants with such disprivileges. Participation of such people 
with disprivileges is crucial both for themselves to be and to feel heard, respected, and included and also for the research impact from a biopsychosocial spiritual and economic perspective.

Step 3. Submitting photos and writing stories (captions). In this step, participants, based on their own perception and decision chose and uploaded the most representative photo one for the most important facilitator and one for the most important barrier. And then, they followed GÖZSAN (meaning SHOWED) acronym explained below to convey their message, that is, their stories and voices in an effective, meaningful, and comprehensive way. Participants did not have to follow SHOWED and yet they were strongly recommended to do so. The researcher recommended participants to write a whole story that includes all or some aspects of SHOWED rather than writing separate sentences or answers for each SHOWED question.

In this third step, participants responded to the SHOWED acronym questions in writing a brief, complete, effective, and meaningful story. The questions were mindfully and contextually adapted to Turkish and were named as GÖZSAN - acronym to facilitate a meaningful story conveyable to others. The SHOWED that is, GÖZSAN, included six questions. GÖZSAN questions facilitated writing of meaningful, comprehensive, and organized stories. The participants were strongly recommended to follow the GÖZSAN questions. In Turkish "GÖZ" means "eye, person" and "SAN" means "assume" and therefore the researchers explained that if as the participants they follow GÖZSAN, other people (eyes/GÖZ) will not assume (SAN) different messages from what participants wanted to convey or at least other individuals will not assume different messages from what participants wanted to convey. Therefore, participants were recommended to follow GÖZSAN when writing their caption or story. The researcher also explained that if the participants did not follow GÖZSAN or write a meaningful comprehensive story, then others (eyes/GÖZ) would be more likely to assume (SAN) something very different from the message desired to be conveyed.

SHOWED acronym is as the following:

$\underline{S}$. What do you $\underline{S}$ ee in the picture as representative of the facilitator/strength/support for you or as part of your life experience during COVID-19? What do you $\underline{S}$ ee in the picture as representative of the barrier/concern/issue for you or as part of your life experience during COVID-19?

$\underline{\boldsymbol{H}}$. What is $\underline{\boldsymbol{H}}$ appening in the picture you have taken? (Briefly describe the picture).

$\underline{\boldsymbol{O}}$. How does that relate to (y) $\underline{\boldsymbol{O}} \mathbf{u r}$ life as a person and/or community?

$\underline{W}$. What is it that contributes to or creates the facilitator (support, strength)? What is it that contributes to or creates the barrier (concern, issue, problem)?

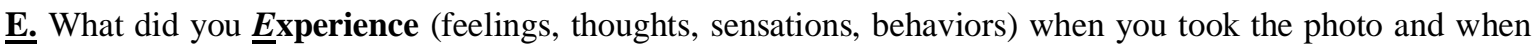
you wrote the caption and then submitted the photo?

$\underline{D}$. What can we (as mental health professionals, peers, university, and all) $\underline{D} \mathbf{o}$ about it?

Step 4. Identifying at least one and at most three themes or metaphors for the facilitator and barrier. At this step, participants reflected on their factor, photo, and caption and came up with at least one and at most three themes or metaphors. Theme or metaphor enables other people to grasp participants' photos and stories in a more meaningful and effective way for a longer time. Theme or metaphors facilitate other people conveying participants' story and intended message to others more effectively. Therefore, the researcher recommended participants not to use more than 10 words for this step and start writing the most comprehensive theme or metaphor at first when they had more than one theme or metaphors.

Step 5. Attributing the facilitator and barrier to one or more levels of EST through a multiple choice question (individual/intrapsychic, microsystem, exosystem, macrosystem). In this step, the researcher asked the participants how they attribute the facilitator (support, strength) and barrier (concern, issue) to one or more levels of Ecological Systems Theory (EST) through a multiple choice question (individual/intrapsychic, micro, exo, macro systems). This is the first OPV study in which the researcher included this step.

The participants first completed their story for facilitator factor and they then completed the barrier story following the SHOWED (meaning GÖZSAN) questions. The researcher combined the questions for the facilitator and barrier, rather than repeating a second time, to save some space in this manuscript due to limited space. 


\section{Analysis}

The researcher followed a theoretical framework perspective and therefore utilized Online Interpretative Phenomenological Analysis (OIPA) to analyze the data. Collaborating with the volunteered partners, the team used the following OIPA's five steps to analyze the data: (1) checking photos and captions for missing information and consent form, (2) examining photos, captions, and themes for confidentiality, (3) classifying facilitator themes under main clusters, (4) classifying barrier themes under main clusters, and finally (5) examining the participants' attribution of themes to EST levels based on their responses to the questions explained in the previous SHOWED section. Tanhan and Strack (2020) followed and explained the first four steps in detail. This was the first time in an OPV study that a researcher asked this fifth step of OIPA and conducted analyses base on the responses to the questions.

\section{Results}

In OPV, Tanhan and Strack (2020) strongly recommended doing the analyses only based on the participants' provided themes though the researchers recommended utilizing other ways and compare these different analysis/analytic approaches (e.g., OIPA vs. traditional IPA). In the present study, the researcher conducted the analyses based only on participants' submitted themes. If a participant did not provide a theme, going with the spirit of OPV, the researcher clustered the themes under the "other" category. Some participants provided more than one theme and therefore they were placed under different main clusters when their themes were different. Some of the participants also included their own, their family or others' faces and personal information; therefore, the researcher edited (e.g., covered the faces with some flowers, replaced personal information with $[\ldots])$ to convey the participants' messages while providing anonymity.

The readers, researchers, and interested ones can access the final anonymous data meaning the submitted photos, captions, and themes related to this study from the following link: https://drive.google.com/drive/folders/1YLf334cpI9aw1wN0ej3CzFOwioj2EEyF?usp=sharing (all submitted in Turkish).

Nineteen main facilitator themes emerged in this present study. These main themes and the percentages for 127 participants are presented in Table 1.

Table 1: Main Facilitator Themes

\begin{tabular}{|c|c|c|}
\hline Main facilitator themes & $\%$ & $\begin{array}{c}\text { Total } \\
\text { number of participants } \\
(127)\end{array}$ \\
\hline 1. Being present at the moment, mindful, attending oneself & 33 & 42 \\
\hline 2. Having family, friends, or relationship with others around & 18 & 23 \\
\hline $\begin{array}{l}\text { 3. Practicing spiritual/religious rituals or activities: transcendence, patience, } \\
\text { gratitude, blessing, prayers, hope }\end{array}$ & 18 & 23 \\
\hline 4. Spending time in nature: garden, village, animal, plant, soil & 17 & 21 \\
\hline 5. Enjoying art: drawing, painting, music, movie, video & 13 & 17 \\
\hline 6. Reading regular books & 12 & 15 \\
\hline 7. Searching for meaning & 12 & 15 \\
\hline 8. Gaining new skills or habits: cooking, drawing, exercise & 11 & 14 \\
\hline 9. Having online/distant education: technology, computer, internet, smartphone & 10 & 13 \\
\hline 10. Doing favors for others: producing and helping out, smiling, having empathy & 9 & 12 \\
\hline 11. Having a good socioeconomic status & 6 & 7 \\
\hline $\begin{array}{l}\text { 12. Local and national institutions like the ministry of health and education } \\
\text { providing professional information and services }\end{array}$ & 5 & 6 \\
\hline 13. Having a daily schedule for work, housework, prayer, entertainment & 4 & 5 \\
\hline $\begin{array}{l}\text { 14. Benefitting from professional mental health services: counseling, Online } \\
\text { Read-Reflect-Share (ORRS) bibliotherapy }\end{array}$ & 4 & 5 \\
\hline 15. Having a healthy diet and cooking enjoyable food & 4 & 5 \\
\hline 16. Doing exercise & 3 & 4 \\
\hline 17. Having faculty and administrators with empathy & 2 & 3 \\
\hline 18. Living alone or with friends rather than with one's family & 2 & 3 \\
\hline 19. Other: participants who did not provide any theme & 11 & 14 \\
\hline
\end{tabular}

Turkish Studies, 15(4) 
Due to space limitations in this manuscript, the researcher provided only one example from the participants' photos, captions, and themes. The researcher chose an example that is quite comprehensive in which the participant followed the research process (e.g., following the five steps and SHOWED acronym).

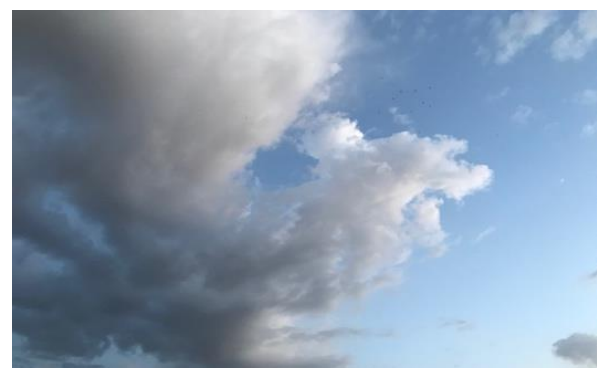

Figure 1: The participant (\#122) submitted the photo to express the most important facilitator (support, strength) during COVID-19

The participant submitted the following story/caption for the facilitator: The developers of OPV strongly suggest conveying the participant's stories as they are without editing except for providing anonymity (Tanhan \& Strack, 2020). The participant translated their story to English voluntarily. Therefore, the researcher did not edit the story.

In this photo you see my pigeons and if you look close you can see them in the clouds. I had to leave the city and go to my village due to the virus. When my pigeons fly, I feel as if I fly into the profound sky. As they rise I feel as if I rise. There are many factors that facilitate my life and I do want to focus on my life at the village and my animals meaning my pigeons. As a college student, I believe we got too far away from nature to the point that we have forgotten we are human beings and need to live with nature. I feel happy when I spend time with my pigeons and other animals my family own. There are many beautiful things in the village such as animals, nature, organic products, fresh air, cheap and even free water and rent, few problems, less crowd, and less noise. However, there are some issues as well. For example, internet is very limited because I am using from my cellphone. Universities and administrators can address these issues so that more people can live at the villages and the virus will spread less. People will feel happier and healthy.

The participant submitted the following themes for the photo and caption: "Nature, animals, village, healthy life"

Twenty-one main barrier (concern, issues) themes emerged from study data. These main themes and the percentages, for 127 participants are presented in Table 2.

Table 2: Barrier/Concern Main Themes

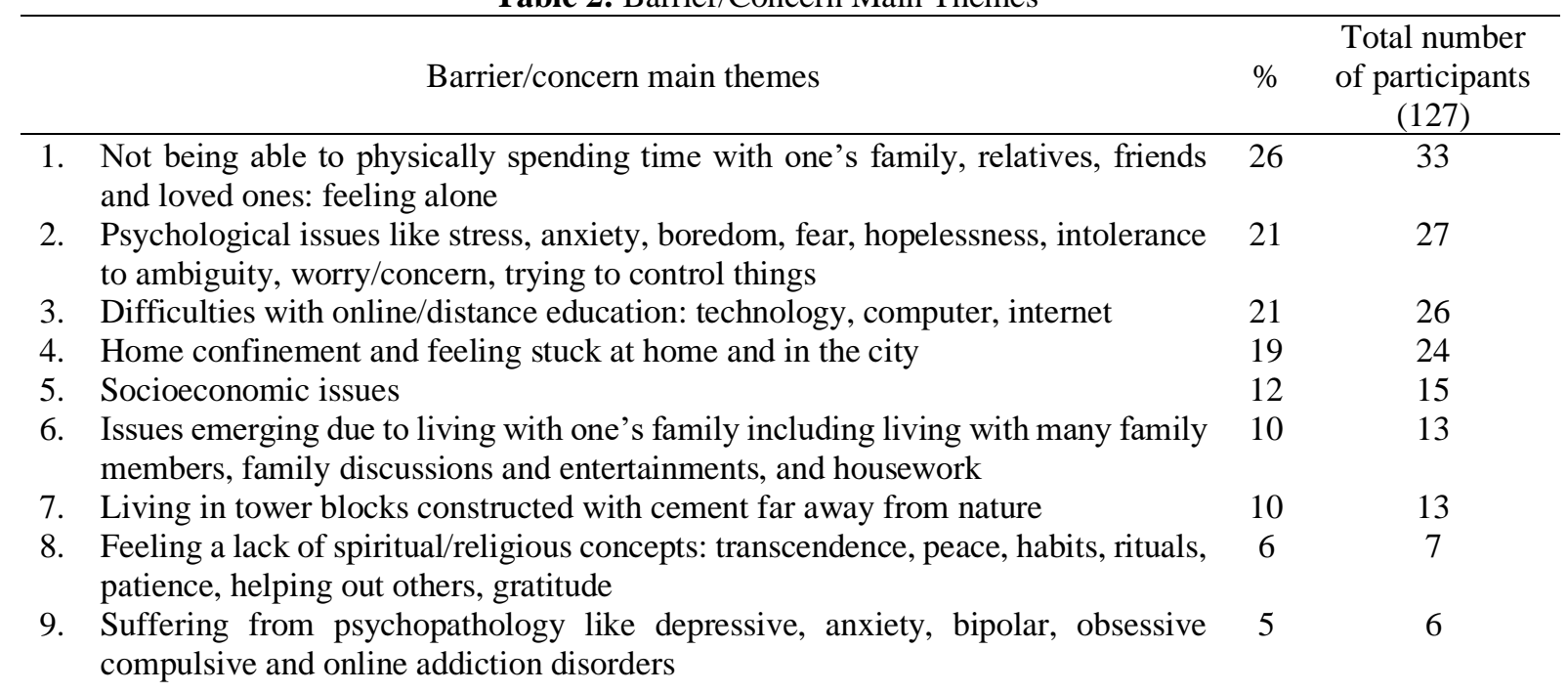


10. Institutions (e.g., ministries of health and education) not addressing COVID-19 $5 \quad 6$ professionally: scary news, bans, rules, big powers exploitation all humanity

11. Lack of following a daily plan for course, housework, and unfinished duties

12. Not having self-time and being present at the moment

13. Lack of infrastructure in terms of internet, road, and health services at villages

14. Feeling worried for the family member working at health settings

15. Lack of empathy among faculty and academic administrators

16. People not following COVID-19 quarantine rules

17. Having unhealthy eating habits

18. Seeing people, with less or no education at all, facing difficulties with following the pandemic rules

19. Not being able to exercise outdoor

20. Spending too much time on television

6

21. Other: participants who did not provide any theme

The following is an example that the researcher chose related to barrier/concern from all participants' photos, captions and themes. The example is quite comprehensive in which the participant seems to have followed the research process (e.g., following the five steps and SHOWED acronym).

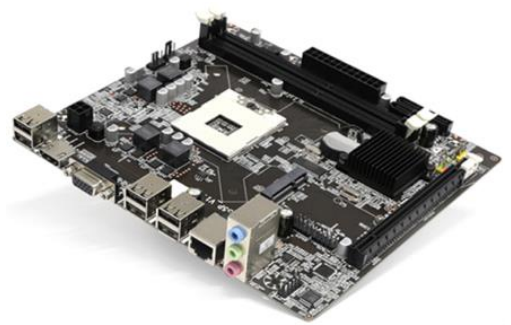

Figure 2: The participant (\#122) submitted the photo to express the most important barrier (concern, issue) during COVID-19

The participant submitted the following story/caption for the facilitator: The developers of OPV strongly suggest conveying the participant's stories as they are without editing except for providing anonymity (Tanhan \& Strack, 2020). The participant translated their story to English voluntarily. Therefore, the researcher did not edit the story.

In this photo you can see the mainboard of a computer. I took this photo from internet with my cellphone. It is pretty complex very similar to my case. I do not have a computer even not a desktop. When I express this, many people do not believe, and indeed I do not have. And if I had it, it would have not been very different because we do not have internet at the village. We had very old computers at the university yet we were able to manage... If I were not with my family and spend time with the animals, I would have gone crazy not because of corona but due to having limited internet through my cellphone and suffering till I use it. Lack of internet, economic difficulties, insufficient infrastructure, though it is rare power cutoff and similar issues seem unimportant but they lead one to get away from one's courses and education. We had thoughtful professors and yet also very meanminded ones whom I think do not know what life means. I do not believe my diploma will help me to get a job in this country. I want to settle in the village, set a ranch, and take care of the animals. I believe researchers and authorities can address the issues in the villages. People dealing with poverty should be considered."

The participant submitted the following themes for the photo and caption: "Economic difficulties, internet and not having a computer, course pressure, professors being mean-minded"

In comparison to other qualitative or traditional photovoice studies, in general, OPV studies generate more main themes because in OPV it is crucial to protect and convey the participants' voice as much as possible 
as in OPV. The present OPV study also generated many themes that could have been merged if the researcher had used traditional IPA or another method for data analysis. In OPV, at least three participants' similar themes lead to construction of a new main theme rather than combining these three participants' themes with other similar main themes.

Study participants attributed facilitators and barriers respectively to various EST levels as follows: individual/intrapsychic factors $(86 \% ; 76 \%)$, microsystem $(10 \% ; 71 \%)$, exosystem (46\%; 58\%), and macrosystem $(35 \% ; 48 \%)$. The researcher and volunteered partners have reached out to key and interested individuals and institutions to share the results with them in order to advocate for enhancing the facilitators and addressing the barriers (concerns, issues). These contacted key individuals and institutions have been interested in the study and results.

Table 3: Participants' Attribution of the Facilitators and Barriers to EST Levels

\begin{tabular}{lllll}
\hline $\begin{array}{l}\text { EST levels and factors } \\
\text { (facilitators and barriers) }\end{array}$ & Individual/Intrapsychic & Microsystem & Exosystem & Macrosystem \\
& & & & \\
\hline Facilitators & $86 \%(n=97)$ & $10 \%(n=11)$ & $46 \%(n=52)$ & $35 \%(n=40)$ \\
Barriers & $76 \%(n=86)$ & $71 \%(n=80)$ & $58 \%(n=65)$ & $48 \%(n=54)$ \\
\hline
\end{tabular}

The readers, researchers, and interested ones can access the final anonymous data, that is, meaning all the submitted photos, captions and themes related to this study from the following link: https://drive.google.com/drive/folders/1YLf334cpI9aw1wN0ej3CzFOwioj2EEyF?usp=sharing (all submitted in Turkish).

Additionally, the researcher found and provided a Facebook group and a Facebook page for this and future OPV research or activities. The participants, researchers and/or any others interested in the topic and/or the results can interact with one another utilizing the group for more critical and meaningful conversations: https://www.facebook.com/groups/OPV.OSF.Online.Photovoice.Seslifoto (the group) and https://www.facebook.com/OnlinePhotovoiceOPV (the page).

\section{Limitations}

There are a few main limitations to this study. First, the researcher conducted the study thoroughly online during COVID-19 pandemic. Therefore, it is more likely that only the participants with electronic and internet resources participated. Second, in order to generalize the results to other populations, one has to consider similar contextual factors; otherwise, the results are limited to 127 college students from the state university in eastern Turkey, where the researcher conducted the study. Third, this is the first time a researcher adapted OPV to Turkish and used it during the difficult time of COVID-19.

\section{Implications}

In light of the implications mentioned above, the researcher provided practical implications in four main areas: research; social services such as health, mental health, local and general administration; education; and advocacy from a holistic and interdisciplinary biopsychosocial, spiritual, economic, and contextual perspective.

\section{Implications in Research}

The results indicate significant research implications. First, the researchers can utilize OPV and the results related to their specific research area (e.g., mental health, education, public health, finance, law, engineering, communication, spirituality, art, architecture) to conduct more robust and in-depth research to understand general public experience during and after COVID-19. Second, future researchers can use OPV with frontline health providers during the COVID-19 and future pandemics to explore the main facilitators and barriers. The third implication of the study is that OPV can be used with populations who are less privileged and are silenced including immigrants, refugees, people living in poverty, seniors and marginal groups due to marginalization or discriminations in terms of religion, race, color, sexual orientation to name a few. Fourth, future researchers can utilize OPV with students in secondary and high schools. Fifth, other researchers may conduct specific OPV studies for each school under the same college, such as school of education, medicine, seminary, finance, and art to name a few, thus being able to access larger cohort samples and coming with 
more specific interventions. Researchers can even utilize OPV at each department (e.g., counseling, mechanical engineering, language, music) at each school to enhance the quality of education within the department and empower its students. Sixth, considering the distinct and constantly evolving aspects professionals (e.g., academicians, mental health providers, people who do recycling, teachers, administrators, doctors) in OPV studies, researchers can focus on each profession separately and examine unique facilitators and barriers to enhance their work functions during the new normal period and after the pandemic is over. This is crucial because many professions face contextual COVID-19 pandemic factors and have to change to survive and be an area of serving people. Seventh, a more specific implication is that researchers can better understand the emerged main facilitator and barrier themes in greater depth and facilitate addressing the related issues by conducting specific OPV studies on these main themes (e.g., social support, role of nature, psychological issues, online or distance education). Another implication of the present study is that OPV can be used as part of quasi-experimental studies, especially in mental health and education fields to see the effects of the services or interventions as reflected in the participants' photos, captions, and themes. The final and perhaps the most important implication is adapting OPV to other languages especially the most spoken ones (e.g., Chinese, Spanish, Arabic, Hindi, Bengali, Portuguese, Russian, French, German, Persian, and Urdu to name a few) that will lend OPV studies to a linguistically and contextually sensitive perspective. Researchers should pay careful attention to the adaptation process so that the adapted version can be just as effective as the English and Turkish versions through protecting the spirit of OPV and its contextual and CBPR perspectives.

\section{Implications in Service}

The first service implication which stands out is that employers and employees can utilize OPV across different professions (e.g., health, education, marketing, transportation, architecture) to provide more effective services. Using OPV can be more effective than some other quantitative surveys or psychometric measures, because OPV allows personal experience to be expressed in an innovative and creative way. Using OPV may facilitate the process of adapting to the new normal via communication technologies and allows for individual and collective voices for all types of participants - employers, employees, clients and institutions. A more specific implication related to OPV study themes is that professionals can focus on the themes related to their area (e.g., architecture, education, mental health, etc.) and examine all the related submitted photos, stories and themes to improve and modify their existing services, accordingly. A few related specific examples: (1) Authorities in charge of local governments can arrange environments and buildings based on a more nature friendly perspective rather than just glass, metal and mortar building blocks far away from nature, provide more green spaces, invest in villages with more greenery and supporting farmers. (2) Health and mental health providers can consider a more holistic biopsychosocial spiritual and economic perspective and collaboration with other professionals and institutions to provide online contextually effective services or when possible face-to-face. (3) Mental healthcare providers can adapt approaches that stress contextual factors, such as Acceptance and Commitment Therapy, and utilize them through online avenues. A final implication of OPV study is that all service providers can consider relevant EST levels to better understand the interrelation of macrosystems: governments and other subsystems (e.g., micro, meso, exo). Therefore, providers can increase awareness of such macro- and microsystems' effects both on advocacy efforts' success and addressing biopsychosocial spiritual and economic wellbeing and issues of individuals.

\section{Implications in Education}

The first education field-related implication is that educators and authorities in charge of education systems should consider a contextual perspective because an acontextual approach is more likely to lead to even more social injustice during difficult times, such as the present COVID-19 pandemic. A contextual perspective is necessary (Alsandor \& Yilmazli Trout, 2020; Doyumğaç et al., 2020; Tanhan et al., 2020) because during such difficult time periods, students and professionals in the education field with less privilege are more likely to experience being stuck at home and not able to use public resources including libraries, friends, and community centers. The second educational implication is that authorities focus on providing reliable internet and technological tools to students in need. Third, students who live in villages without internet or have serious issues with their families can be provided with options to stay on campus while following the social distancing rules for the pandemic. Fourth, authorities and engineers can work together to come up with better-suited structural design for dormitories or student housing which are nature friendly. Students and staff living on campuses can gain resiliency and be healthier biopsychosociallly, spiritually and economically if they are close to one another and have natural greenery surrounding. Students, health providers serving patients,

Turkish Studies, 15(4) 
and ones affected by COVID-19 pandemic need nature-friendly houses, as having natural spaces (for living while following physical social distance) will likely have a positive effect on their biopsychosocial spiritual and economic wellbeing. Finally, it will allow them to still feel being part of a group or community. Having this sense of community will help with addressing the issues because long-term physical isolation and losing sense of one's community can be detrimental to human biopsychosocial spiritual and economic aspects (Tanhan et al., 2020). Another crucial implication related to this living environment is having buildings for living and education in greenery environment and with less floors/apartments, more openable windows so that buildings can get more natural air without using ventilators, and more green space between. In this way, people living in the buildings can be a community while having enough space to protect social distance, spend time outdoors in their garden, and socialize while all stay in their gardens. Another educational implication of OPV is that educators can provide students with more reflective, meaningful, and mindful assignments: optional projects; using take home exams, projects or assignments with extended time rather than multiple choice exams with very limited time; utilizing easier grading systems and include intellectually stimulating activities (e.g., assign meaningful contemporary books to read, complete self-compassion exercises, and so forth).

\section{Implications in Active Interdisciplinary Social Advocacy}

In the context of difficult pandemics and a global village world, professionals adopt an interdisciplinary focus while each professional gradually becomes even more specialized in their subtopic. A comprehensive biopsychosocial spiritual and economic perspective can be helpful in meeting various goals. They need to consider this comprehensive perspective at each level of EST, meaning that general wellbeing and psychopathology is constructed by all systems of EST. Policy changes in larger macrosystems, such as governments can successfully occur through concerted and active interdisciplinary social advocacy campaigns through the use of OPV. While systems affect one another, it is important to stress that the effect of larger macrosystems, such as governments, is much larger in terms of its intensity and its prolonged effect. Therefore, all professionals and interested ones in this study can pay careful attention to act with an active social advocacy perspective while considering the implications mentioned above. Otherwise, the professionals will run the risk of not having a comprehensive lens on facilitator and barrier factors, thus, unintentionally, disempowering public in the face of unfair systemic problems of exploitation, poverty, and discrimination. This means, all professionals interested in the results of this study can advocate at each level of EST to reach out to other key counterpart individuals, groups at other institutions as well as local and national authorities to enhance facilitative factors and address barriers. Wider advocacy efforts can raise much needed awareness and maximize efficient use of community resources. Professionals, researchers, or lay people can do a lot at individually, and yet they can do much more in a short time at a systemic level when they advocate at all levels of EST. Such an advocacy is more likely to maximize the already available community resources and even build more community capacity, which will bring long-term enhancement at all levels for all.

\section{Discussion and Conclusion}

The current results and ongoing advocacy indicate that the adapted OPV study with the applied theoretical framework can be best utilized to examine and address biopsychosocial, spiritual, economic and other contextual issues at the individual, group and/or community levels during the COVID-19 pandemic. The researcher found similar results in other quantitative and qualitative COVID-19 research with college students. However, the researcher also found the present study unique in terms of its innovative method and specific results (e.g., students asking for appropriate buildings, wanting to live on campus, seeking spiritual activities and identifying lack of spirituality as one of the most important barriers) that contribute a significant value to the related literature. OPV seems to be a much more effective and reliable form of sharing lived experiences based on life story narratives and for engaging in self-advocacy efforts especially during difficult times (e.g., pandemics, endemics, conflicts, lack of safety,) when it is relatively difficult to get out and meet others faceto-face. OPV also provides crucial advantages like reaching out to disempowered, silenced, and underprivileged diverse groups while protecting their anonymity. The researcher also experienced that having partners from a CBPR perspective facilitates reaching out to more diverse participants because the partners in this and other previous studies kept asking if it was alright to pass on the research link to other students and the general public. However, as explained above, this was a pilot study where people who benefited from or provided services at the clinic; therefore, we asked only the students who were benefitting from the clinic or providing services at the clinic to participate in the study. Other researchers also acknowledged how partners or allies in their research fields facilitated reaching out to many diverse groups of interested participants in a 
relatively short period of time (Tanhan \& Francisco, 2019). In summary, both in Turkish and English language, OPV seems to be a robust method to enhance wellbeing and address identified barriers (concerns, issues) related to human biopsychosocial spiritual and economic aspects when used with the theoretical framework as the present researcher followed in this study.

Keywords: Counseling, COVID-19, Online Photovoice (OPV) Methodology, Ecological Systems Theory (EST), Public Health, Mental Health, Education, College Students, Biopsychosocial Spiritual Economic Issues, Community-Based Participatory Research (CBPR), Community-Based Participatory Action Research (CBPAR), Ally Development, Pandemic, Spirituality, Social Justice, Active Social Advocacy, Online Interpretative Phenomenological Analysis (OIPA), Community Psychology, Photovoice, Method, Technique

Note 1: This paper includes extra-extended abstract of the manuscript in English language on these first pages. Then the full Turkish version of the paper starts.

Note 2 for acknowledgment: I, as the researcher, do deeply thank all who supported the research and writing process. I have thanked all who helped and understand Turkish at the end of the Turkish section of this manuscript. However, I do want to take a few lines here to acknowledge support from dear colleagues, who do not understand Turkish, deeply appreciate my colleagues' Saira Qureshi's, from the USA, and Habil Otanga, $\mathrm{PhD}$ from Kenya, for the support for this research and manuscript.

Note 3: The researcher humbly dedicates this work first and foremost to the ones lost their lives due to the COVID-19 pandemic and their relatives who most probably have not had a grief process based on their values. And second, the researcher dedicates this work to all people who have suffered from COVID-19 and keep strugglign due to its prolonged biopsychosocial spiritual and economic effects. Third, the researcher dedicates this work to all seniors all around the world who could or could not have a graduation ceremony aligning with their values during this difficult COVID-19 pandemic. And Finally, the researcher dedicates this work to his clinical assistans who mindfully struggle to for a more livable and meaningful world for all.

Öz: $\mathrm{Bu}$ araştırmada yazar (1) COVID-19 sürecinde üniversiteli öğrencilerin yaşamını kolaylaştıran ve zorlaştıran en önemli biyolojik, psikolojik, sosyal, manevi/spiritüel ve ekonomik faktörleri Online Seslifoto tekniğini (OSF) kullanarak katılımcıların kendi biricik perspektifinden incelemiş; (2) katılımcılardan gönüllü olanlarla beraber sonuçları online yollarla ilgili ve yetkili kişilere ulaştırarak yaşamı kolaylaştıran faktörlerin ihtiyaç duyulan düzeyde arttırılması ve zorlaştıran faktörlerin ise etkili bir şekilde ele alınarak meselelerin çözüme kavuşturulması için aktif sosyal savunuculuk yapmış; (3) katılımcıların kolaylaştırıcı ve zorlaştırıcı faktörleri Ekolojik Sistemler Teorisinin (EST) hangi sistemlerine atfettiğini belirlemiş ve son olarak (4) OSF'nin İngilizcede yani orijinal hâlinde kullanıldığı kadar Türkçede de işlevsel bir şekilde kullanılabilmesi için bağlamsal bir perspektiften OSF'yi Türkçeye uyarlamış ve kullanmıştır. Araştırmanın teorik çerçevesini Ekolojik Sistemler Teorisi (EST) bağlamında Topluluk Temelli Katılımlı Araştırma (TeTKA) oluşturmuştur. Veri toplamak için nitel yöntemler arasında yer alan OSF tekniği ve veriyi analiz etmek için Online Yorumlayıcı Fenomenolojik Analizi (OYFA) yaklaşımı kullanılmıştır. Araştırmaya toplamda 148 üniversite öğrencisi katılmış; 127 kişi onam formunu onaylayarak nihai örneklemi oluşturmuştur. Kolaylaştırıcı faktörler 19 ana tema oluşturmuştur; en önemli kolaylaştırıcı ana temalar ve oranları şöyle olmuştur: Kendinde yani mindful olma (\%32), aile/arkadaş ilişkileri (\%18) ve maneviyat/spiritüalizm (\%18). Zorlaştırıcı faktörler 21 ana tema oluşturmuştur; en önemli zorlaştırıcı ana temalar ve oranları şöyle olmuştur: sevilen insanlarla fiziki olarak beraber olamamak (\%26), psikolojik meseleler (\%21) ve online/uzaktan eğitim (\%21). Katılımcılar kolaylaştırıcıları ve zorlaştırıcıları EST sistemlerine sırasıyla şöyle atfetmiştir: Bireysel/içsel (\%86; \%76), mikrosistem $(\% 10 ; \% 71)$, ekzosistem $(\% 46 ; \% 58)$ ve makrosistem $(\% 35 ; \% 48)$. Araştırmac1 ve gönüllü katılımcılar sonuçları ilgili ve yetkili kişilere gerçek ve online ortamlarda ulaştırarak kolaylaştırıcıların ve zorlaştırıcıların ihtiyaç düzeyine göre ele alınıp genel hayat kalitesinin artırılması ve meselelerin çözüme kavuşturulması için aktif sosyal savunuculuk yapmıştır. Yazar araştırma, sağlık ve yönetim gibi hizmet verme, eğitim ve aktif savunuculuk gibi dört temel alan için spesifik uygulamalar önermiştir. Bu dört temel alandaki profesyonel çalışanlar insanların biyopsikososyal manevi ve ekonomik durumunu bütüncül bir perspektiften hem pozitif hem de anormal psikoloji perspektifinden anlamak, yaşam kalitesini EST'nin tüm düzeylerinde senkronize ve dengeli bir şekilde artırmak ve yaşadıkları meseleleri en etkili şekilde ele almak için OSF'yi ve mevcut araştırmanın sonuçlarını kullanabilir. OSF'nin insanları manipüle etmeden yaşadıkları durumu onların

Turkish Studies, 15(4) 
biricik perspektifinden anlama noktasında, özellikle de insanların yüz yüze bir araya gelmesinin zor olduğu pandemi, endemi, savaş ve doğal afet durumlarında veya katılımcıların çok olduğu durumlarda diğer birçok nitel tekniğe göre avantaj sağladığı görülmüştür. Araştırmacı bu çalışma için etik kurul izni almıştır.

Anahtar Kelimeler: Psikolojik Danışmanlık, COVID-19, Online Seslifoto (OSF) Metodolojisi, Ekolojik Sistemler Teorisi (EST), Halk Sağlığı, Ruh Sağlı̆̆ı, Eğitim, Üniversite Öğrencisi, Biyopsikososyal Manevi Ekonomik Meseleler, Maneviyat, Spiritüalizm, Rehberlik, Topluluk Temelli Katılımlı Araştırma (Tektaş), Pandemi, Sosyal Adalet, Aktif Sosyal Savunuculuk, Online Yorumlayıcı Fenomenolojik Analiz, Toplum Psikolojisi, Seslifoto, Sesfoto, Yöntem, Teknik

\section{Giriş: COVID-19 ve Genel Biyopsikososyal Manevi Ekonomik Etkileri}

Yaygın bilinen adıyla Koronavirüs Hastalığı veya COVID-19'a Şiddetli Akut Solunum Sendromu Koronavirüs 2 (Severe Acute Respiratory Syndrome Coronavirus 2; SARS-CoV-2) virüsü neden olmakta ve hastalık daha önce Yeni 2019 Korona Virüs adıyla bilinmekteydi (Dünya Sağlık Örgütü [DSÖ], 2020). Çin'in, Hubei eyaleti Wuhan şehrinden dünyaya yayıldığı söylenen virüs kısa bir zamanda tüm dünyaya yayılarak (Huang vd., 2020) çok ciddi beklenmedik biyopsikososyal (biyolojik, psikolojik, sosyal), manevi/spiritüel ve ekonomik sorunlara neden olmuş ve neden olmaya devam etmektedir (Tanhan vd., 2020). Bu makalede araştırmacı spiritüalizm ve maneviyat kavramlarını birbiri yerine yani aynı anlamda kullanmıştır. Araştırmacı bu iki kavramı katılımcı, inandıkları belirgin bir dini inanç olsun ya da olmasın, kendisinin ötesinde ve kendisini aşan bir aşkınlıktan (örn., insanlık, keşfedilmesi gereken bir mesaj, içsel huzur) bahsettiğinde kullanmıştır. COVID-19 pandemi sürecinde insanlar birçok psikopatolojik durum yaşayabilmektedir: davranışsal problemler (Cortese vd., 2020), depresyon, kaygı (Çıtak \& Pekdemir, 2020; Çiçek vd., 2020), tedirginlik, travma sonrası stres bozukluğu (Bao vd., 2020), tükenmişlik (Chen vd., 2020). Ayrıca insanlar henüz psikopatolojiye dönüşmemiş korku, can sıkıntısı, belirsizlik, çatışmalar, amaçsızlık, zararlı haberlerin akıntısına kapılma gibi hoşa gitmeyen duygu, düşünce ve bedensel hisler yaşamaktadır (Arslan vd., 2020; Haktanir vd., 2020; Tanhan vd., 2020). Bu durumlar az da olsa intihar gibi ağır tablolarla sonuçlanabilmektedir (Maymun \& Griffith, 2020). Bu zor durumlarda profesyonel bilgi eksikliği, internette dolaşan kanıtsız haberler ve mitler insanların yaşadığı durumu daha sorunlu hâle getirmekte ve sağlıklı olmayan yollara yönlendirmektedir (Boa vd., 2020; Tanhan vd., 2020).

Biyopsikososyal manevi bir varlık olan insanın bu süreçte aşırı ve bilinçsizce izole olması, zararlı içerik ve süreçlere maruz kalması ve dolayısıyla teknoloji (örn. internet, akı1lı telefon, oyun) bağımlılığı gibi psikolojik açıdan işlev bozucu süreçlere girme riskinin önüne geçilmesi acil önem arz etmektedir (Tanhan vd., 2020). Bu araştırmacılar yalnız kalma veya hissetmenin insanın bağışıklık ve denge sistemini bozan en önemli faktörlerden birisi olduğunu ifade etmişlerdir. $\mathrm{Bu}$ süreçte ortaya ç1kan ve süreç bittiğinde yüksek olasıllkta görülecek olan biyopsikososyal manevi ve ekonomik sorunların işlevsizliğe yol açmadan önlenmesi ve oluşmuş ve oluşacak geçici veya kalıcı zararlara profesyonel bir şekilde müdahâle edilmesi gerekmektedir. Psikopatoloji kaygı verici şekilde gelişebilmekte ve bazı durumlarda çok uzun sürüp çok ciddi maddi ve manevi kayba neden olabilmektedir (Erdem \& Bucaktepe, 2012; Tanhan vd., 2020; Tombul vd., 2005). Bundan dolay1 COVID-19 salgını sürecinde kısa, orta ve uzun vadede ortaya çıkabilecek biyopsikososyal, spiritüel ve ekonomik olarak yaşanan zorluk, sıkıntı veya problemleri ele almak ve genel hayat kalitesini teorik olarak iyi oturtulmuş, etkililiği bilimsel olarak sınanmış bilimsel uygulamalarla desteklemek büyük önem arz etmektedir (Arslan vd., 2020; Çiçek vd., 2020). COVID-19'a ilişskin kapsamlı akademik alanyazın taramasında araştırmacılar hem ruh sağlığı uzmanlarına hem de yöneticilere pandemi sürecinde kanıta dayalı profesyonel hizmetler için acil çağrıda bulunmuştur (Alsandor \& Yilmazli Trout, 2020; Bao vd., 2020; Doyumğaç vd., 2020; Otanga vd., 2020; Tanhan vd., 2020; Yao vd., 2020). Ergenlik döneminin getirdiği gelişimsel durumlar, ani bir şekilde üniversiteden ayrılma, beklenmedik şekilde aileyle yaşamaya başlama ve ekonomik sıkıntılar gibi bağlamsal diğer 
faktörler de üniversiteli öğrenciler için önemli birtakım sorunlara yol açmıştır (Genç vd., 2020b; Sever \& Özdemir, 2020; Tanhan vd., 2020).

\section{Türkiye Bağlamında COVID-19 ve Biyopsikososyal Manevi ve Ekonomik Sorunlar}

Türkiye'de COVID-19 üzerine yapılan bilimsel araștırmalara dair kapsamlı bir literatür araştırması yapıldığında, COVID-19'a yönelik bilimsel araştırmaların büyük bir kısmının medikal eksenli olup çok azının ruh sağlığı alanına yönelik olduğu bulunmuştur (Arslan vd., 2020; Çiçek vd., 2020). Bu araştırmalarda araştırmacıların bazıları şu konulara odaklanmıştır: Epidemilerin tarihi (Afacan \& Avc1, 2020; Özkoçak vd., 2020), pandeminin hemşirelik mesleğine etkisi (Çevirme \& Kurt, 2020) anestezi uzmanlarının COVID-19 hastalığını taşıyanlara karşı tutumları (Dost vd., 2020), yoğun bakım ünitelerine dikkat edilmesi (Halaçlı vd., 2020), hastalığın doğası (Hasöksüz vd., 2020) ve gelişim süreci (Petersen \& Gökengin, 2020). Diğer bazı araştırmacılar ise hastalığın tarıma (Torun Kayabaş1, 2020), işçilere (Aksoy \& Mamatoğlu, 2020; Göze Kaya, 2020; Korkmaz, 2020), ekonomiye (Açikgöz \& Günay, 2020; Akca, 2020; Güler, 2020; Macit \& Macit, 2020; Soylu, 2020; Şenol \& Zeren, 2020), e-ticarete (Güven, 2020) ve evden çalışmaya (Kara, 2020) olan etkisini incelemiştir.

Bu araştırmaların yanı sıra bazı araştırmacılar hâlkın hastalığa karşı olan genel yaklaşımını ele almıştır (Bostan vd., 2020; Dushıme \& Hashemıpour, 2020). Bu araştırmalardan farklı olarak yayımlanan bazı istisnai araştırmalar ise genelde psikopatolojiye odaklanmıştır (Arslan vd., 2020; Çiçek vd., 2020; Haktanir vd., 2020). Katılımcılar COVID-19 sürecinden öncesine göre çok daha fazla ulusal ve sanal medyada ve genel olarak internette zaman geçirdiğini ve çoğunun profesyonel kaynaklardan bilgilenmeye dikkat etmediklerini ifade etmişlerdir (Çiçek vd., 2020). Araștırmacılar hâlkın genelinde genel bir COVID-19 stresi, kaygısı (Arslan vd., 2020) ve korkusu oluştuğunu bulmuşlardır (Haktanir vd., 2020; Satici vd., 2020). Tüm bu araştırmalarda psikometrik özelliklere sahip nicel ölçeklerden yararlanarak katılımcıların biricik perspektiflerini ve deneyimlerini ortaya çıkaracak nitel ve özellikle de inovatif teknikler çok az kullanılmıştır. Dünya genelinde ve Türkiye'de birçok ruh sağlığı uzmanı ve araştırmacısı uygulamaya dönük, teorik alt yapısı sağlam ve bağlamsal olarak uygun online ve yenilikçi COVID-19 ruh sağlı̆̆ araştırmaları ve hizmetleri için acil çağrıda bulunmuştur (Bao vd., 2020; Tanhan vd., 2020). Tanhan ve arkadaşları (2020) kapsamlı literatür taramasında Türkiye'de teorik ve uygulamalı araştırma ve hizmetlerde kanıta dayalı programların veya bilimsel teorilerle desteklenmiş ve iyice yapılandırılmış kuramsal çerçevelerin eksik olduğunu açıklamışlardır. Bu araştırmacılar mevcut araştırmanın teorik yani kuramsal çerçevesini oluşturan Ekolojik Sistemler Teorisi (EST) bağlamında Topluluk Temelli Katılımlı Araştırma (TeTKA) ile Online Seslifoto'nun (OSF) beraber kullanımını önermişlerdir. Araştırmacı bu makalede Topluluk Temelli Katılımlı Araştırma için TeTKA kısaltmasının okunma ve hatırlanmasının zihinsel açıdan çok daha kolay olduğunu kendisi ve en önemlisi de bu çalışmada TeTKA perspektifinden paydaş olarak gönüllü olanlar tecrübe etmiştir. Bu yüzden bu makalede TeTKA kısaltması tercih edilmiştir.

\section{COVID-19 Sürecinde Türkiye'de Online Ruh Sağlığı Araştırmaları}

Araştırmacılar Türkiye'de genel olarak ruh sağlığı hizmetlerinin (Arslan \& SommersFlanagan, 2018; Balcığlu \& Balcığlu, 2018; Kalkan \& Can, 2019; Nesipoğlu, 2017; Özyürek, 2019) bazı temel sorunlarının olduğunu raporlaştırmışlardır. Bazı araştırmacılar da Türkiye'de özellikle COVID-19 sürecinde ruh sağlığı hizmetleri ve araştırmalarının sistematize olmadığını ve bunun ilköğretimdeki öğrencileri (Avci, 2020a), üniversiteli öğrencileri (Tanhan vd., 2020), öğretmenleri (Çiçek vd., 2020), akademisyenleri (Doyumğaç vd., 2020; Tanhan vd., 2020) ve halkın genelini (Arslan vd., 2020; Tanhan vd., 2020) etkilediğini rapor etmiş ve bunun birçok soruna yol açtığını ifade etmişlerdir. Ruh sağlığı hizmetleri yasasının olmaması, önerilen yasa tasarılarının psikolojik danışman, psikolog, psikiyatri hemşiresi ve klinik sosyal hizmet uzmanı gibi ruh sağlığ profesyonellerini açıkça ve kapsayıcı bir şekilde içermemesi ve halkın ihtiyaç duyduğu psikolojik 
danışmanlık veya terapi görüşmelerinin çok uzun aralıklarla çok az sayıda verilmesi ya da hiç verilmemesi hâlkı doğrudan etkileyen sorunların başında gelebilmektedir. Mevcut araştırmanın yazarı diğer psikolojik danışman, psikiyatrist ve psikolog gibi diğer ruh sağlığı uzmanları ile COVID-19 sürecinde klinik araştırmalarından dolayı bütüncül bir perspektiften çalışmış ve yukarıda sayılan sorunlar yüzünden de danışanlara zorlu pandemi sürecinde istenilen düzeyde hizmet verilememiştir.

Bilimsel araştırmalar için de etik kurul izinlerinin alın(a)maması, bazı üniversitelerde etik kurulun bulunmayışı, son zamanlarda kurulmuşların çok yavaş işlemesi, kuramsal çerçeveler olmadan araştırmaların yapılması, aynı konuda aynı yerde aynı veriyi toplayan araştırmaların olması, ağırlıklı olarak ölçeklerin kullanılıp nicel araştırmaların yapılması, psikopatolojiye ağırlık verilmesi, pozitif psikoloji perspektifine çok az yer verilmesi ve son olarak yenilikçi nitel ve nicel tekniklerin çok az kullanılması bilimsel araştırmaları ve özellikle de ruh sağlığı alanındaki gelişmeleri yavaşlatmaktadır.

Başka önemli bir nokta ise araştırma yapan ve hizmet veren ruh sağlığı uzmanlarının insanların biyopsikososyal manevi ve ekonomik meselelerine bütüncül ve önleyici bir perspektiften yaklaşmaması daha çok problem/psikopatoloji odaklı araştırmalar yapmasıdır. Bu araştırmada mesele kelimesi insanların hayatında genelde henüz çok büyük sorun oluşturmayan ancak genel iyilik hâllerini düşürebildiği için ele alınmayı gerektiren zorluk, sıkıntı ve rahatsızlıkları tanımlamak için kullanılmıştır. Başka bir deyişle, bu araştırmada mesele kelimesi çoğunlukla bireyin, grupların veya toplumun işlevselliğini engelleyecek düzeyde psikopatolojiye dönüşmemiş durumlar için kullanılmıştır. Bunlara ek olarak başka önemli bir eksiklik ise araştırmacıların çok büyük bir kısmının genelde durumu tanımlayıcı (descriptive) araştırmalar yapıp hâlkın biyopsikososyal manevi ve ekonomik meselelerini ve genel iyi oluş düzeyini bağlamsal ve etkili bir şekilde ele almaya yönelik aktif savunuculuk perspektifinden hareket etmemesidir. Tanhan ve arkadaşlarının (2020) araştırması bu noktada bir istisna oluşturmuş, araştırmacıların disiplinler arası bir araştırma ile hâlkın, özellikle de üniversiteli öğrencilerin biyopsikososyal manevi ve ekonomik meselelerini ele aldığı, genel iyi oluş düzeylerini artırmak için online ruh sağlığı hizmetlerini sağladığı ve bu hizmetlerin sistemsel olarak idame ettirilmesi için yerel ve ulusal düzeyde aktif sosyal savunuculuk yaptıkları görülmüş̧ür.

Tüm bu sayılanların 1şığında, mevcut araştırmada yukarıda sayılan eksikliklerin bir kısmı (örn., etik izin, bütüncül bir perspektiften hareket etme gibi) giderilerek inovatif nitel bir teknik olan OSF'nin Türkiye'de COVID-19 sürecinde üniversite öğrencilerinin hem normal hem de anormal psikoloji perspektifinden ele almak ve genel iyi oluş düzeylerini artırmak için aktif savunuculuk yapılmıştır.

\section{Türkiye'de ve Dünyada Üniversite Öğrencileriyle COVID-19 Bağlamı}

COVID-19 süreci birçok insan için biyopsikososyal manevi ve ekonomik olarak çeşitli sonuçlar doğurmuştur (Arslan vd., 2020; Çiçek vd., 2020; Doyumğaç vd., 2020; Haktanir vd., 2020) ve bu durum özellikle de üniversiteli öğrencileri ciddi bir şekilde etkilemiş bulunmaktadır (Akyol vd., 2020; Çetin \& Anuk, 2020; Gençalp, 2020; Gumusgul \& Aydoğan, 2020; Kürtüncü \& Kurt, 2020; Sarıtaş \& Barutçu, 2020). Tanhan vd. (2020)'ne göre COVID-19 sürecinde Çin (Cao vd., 2020), Kenya (Otanga vd., 2020) ve ABD (Rose, 2020; Alsandor \& Yilmazli Trout, 2020) gibi ülkelerdeki üniversiteli öğrencilerle yapılan araştırmalarda ve konu üstüne yapılan sistematik alanyazın taraması araştırmalarında da (Viner vd., 2020) üniversitelilerin birçok sıkıntı yaşadığı görülmüştür.

COVID-19'dan önce de Türkiye'de yapılan araştırmalarda üniversite öğrencilerinin biyopsikososyal manevi ve ekonomik meselelerle uğraştığı görülmüş̧ür (Akın, vd., 2014; Belen \& Yıldırım, 2020; Büyükşahin Çevik vd., 2016; İkiz vd., 2015; Kızıldağ vd., 2012; Sarıçam vd., 2014; Tanhan vd., 2020; Yavuz vd., 2011). Benzer şekilde COVID-19'dan önce de dünyanın farklı 
ülkelerindeki üniversite öğrencilerinin biyopsikososyal manevi ve ekonomik sorunlar yaşadığ1 görülmüş̧ür (Becker vd., 2015; Ermis-Demirtas vd., 2018; Haktanir vd., 2018; Karaman \& Watson, 2017; Krafft vd., 2019; Otanga vd., 2020; Tanhan, 2018; Tanhan \& Francisco, 2019; Yilmazli Trout vd., 2019). Bu yüzden bazı araştırmacılar hem Türkiye hem de dünyada özellikle de COVID-19 bağlamında üniversite öğrencilerinin yaşadığı sıkıntıları ele almak ve genel iyilik hâlinin yükseltilmesi için inovatif bir teknik olan OSF'yi kullanmak için öneride bulunmuştur (Tanhan \& Strack, 2020; Tanhan vd., 2020).

\section{Literatürdeki Boşluklar}

Ruh sağlığı alanında gittikçe önem kazanan pozitif psikoloji ruh sağlığı alanında hâla hak ettiği değeri görememektedir (Arslan vd., 2020; Demir \& Türk, 2020; Haktanir vd., 2016). Zor durum veya koşullarda kalan insanoğlu pozitif psikoloji perspektifinden birtakım hazır kaynakları kullanırken aynı zamanda o güne kadar hiç kullanmadığı veya farklı düzeylerde kullandığı bireysel, toplum ve devlet düzeyindeki sistemik potansiyellerini, yani psikolojik sağlamlığını oluşturan kaynakları, harekete geçirebilmektedir (Genç vd., 2020; Mills, 2020; Tanhan vd., 2020). Başka bir deyişle biyopsikososyal spiritüel bir varlık olan insan zor durumların etkisinden dolayı sadece psikopatoloji geliştirmemekte aynı zamanda yeni birtakım kaynaklar da oluşturabilmektedir. Yani psikolojik sağlamlığını da artırabilmektedir. COVID-19 araştırma alanyazına bakıldığında hem Türkiye'de hem de dünyada genellikle katılımcıları belli bir düzeyde sorularıyla yönlendiren ölçek ve nicel araştırmaların daha yaygın olduğu ve genellikle de psikopatolojiye, yani neyin yolunda gitmediğine odaklandığı görülmektedir. Daha da spesifik olarak inovatif tekniklerin çok az olduğu; örneğin fotoğrafların araştırmalarda kullanımı üstüne yazılan Türkçe literatürü mevcut araştırmanın yazarı taramış ve OSF kadar kapsamlı ve inovatif bir teknik sunmaktan ziyade görsel materyallere dayalı tüketici araştırmaları literatür taraması hakkında bilgi veren Uygun (2011)'un araştırmasını bulmuştur. Bazı araştırmacılar (Tanhan \& Strack, 2020; Tanhan vd., 2020), endemi veya pandemi gibi zor süreçlerden geçen insanlarla araştırma yaparken, OSF gibi katılımcılara yaşamlarındaki zorlukların yanında neyin iyi gittiğini soran ve bunları analiz eden inovatif araştırma tekniklerinin faydalı olacağını belirtmişlerdir.

\section{Araştırmanın Amacı}

$\mathrm{Bu}$ araştırmanın dört temel amacı vardır. Birincisi COVID-19 sürecinde üniversiteli öğrencilerin biyopsikososyal spiritüel ve ekonomik olarak yaşamını kolaylaştıran ve zorlaştıran en önemli faktörleri OSF yoluyla katılımcıların kendi biricik perspektifinden anlamak; ikincisi katılımcılardan gönüllü olanlarla beraber sonuçları online yollarla ilgili ve yetkili kişilere ulaştırarak yaşamı kolaylaştıran faktörleri ihtiyaç duyulan düzeyde artırmak ve zorlaştıran faktörleri etkili bir şekilde ele alarak meselelerin çözüme kavuşturulması için aktif savunuculuk yapmak; üçüncüsü katılımcıların kolaylaştırıcı ve zorlaştırıcı faktörleri EST'nin hangi düzeylerine atfettiğini belirlemek; dördüncüsü OSF'yi orijinaline uygun bir şekilde Türkçeye uyarlamak, kullanmak ve ileriye yönelik araştırma ve hizmet alanları başta olmak üzere önerilerde bulunmaktır.

\section{Araştırmanın Özgün Değeri}

Araştırmacı yukarıda sayılan alanyazındaki boşlukları kısmen gidermiş ve önceki araştırmalarda önerildiği gibi iyice temellendirilmiş bir kuramsal çerçeve kullanmıştır. Araştırmacı hedeflediği dört temel amaca ulaşmıştır. Gönüllü katılımcılarla hareket eden araştırmacı ikinci temel amaç olan araştırmanın sonuçlarını aktif savunuculuk yoluyla ilgili kişi, kurum ve kuruluşlara ulaştırarak anlamlı ve kritik diyaloglar geliştirmeye devam edilmektedir. Tüm bunlardan dolayı araştırmanın özgün değeri oldukça yüksektir. 


\section{Teorik Çerçeve: COVID-19 Sürecinde OSF'yi Ekolojik Sistemler Teorisi (EST) bağlamında Topluluk Temelli Katılımlı Araştırma (TeTKA) ile Kullanma}

Araştırmanın teorik çerçevesini Ekolojik Sistemler Teorisi (EST), Online Seslifoto (OSF) ve Topluluk Temelli Katılımlı Araştırma (TeTKA) oluşturmuştur. Bu teorik çerçeveye uygun olarak da verinin analizinde Online Yorumlayıcı Fenomenolojik Analizi (OYFA) yaklaşımı kullanılmıştır. Tüm bunları tamamlayan ve araştırmada elde edilen verilerin daha da anlamlı olması için ve özellikle de OSF ve TeTKA'nın ve çalışmanın altyapısını oluşturan çok önemli bir kavram da aktif savunuculuk olmuştur.

\section{Ekolojik Sistemler Kuramı (EST)}

Bronfenbrenner (1977) bireyler üzerinde yaşamları boyunca etki katmanları sağlayan çoklu faktörlere ilişkin kapsamlı bir gelişimsel çerçeve sunmak için EST'yi geliştirmiştir. Bronfenbrenner tarafından tanımlanan ve bireyin dinamik günlük bağlamlarını oluşturmak ve etkilemek için etkileşime giren beş ana sistem şunlardır: (1) Mikrosistem (ev, okul vb. yakın bağlam), (2) mezosistem (mikrosistem ile ekzosistem arasındaki ilişkileri içeren sistem), (3) ekzosistem (medya, komşular, sosyal hizmetler, yerel yönetimler, yerel kuruluşlar gibi bireyi dolaylı olarak etkileyen unsurları kapsayan sistem) ve (4) makrosistem (kültür, hükümet, ekonomi ve toplumsal özellikleri içeren sistem) (Bronfenbrenner, 1979) ve araştırmacıların daha sonra eklediği bireyin gelişimini etkileyen, savaşlar ve ekonomik daralmalar gibi zaman içerisindeki yaşam olaylarının oluşturduğu (5) kronosistem (Bronfenbrenner \& Evans, 2000).

Birey modelin merkezindedir ve bu söz konusu sistemler bireyin etrafinda yuvalanmıştır (Tanhan, 2019). Bu sistemler bireyi sürekli olarak etkilediği gibi bireyler de bu sistemleri etkilemektedir. Ancak çeşitli ekolojik sistemlerin büyüklüğü ve kapsamı, örneğin makrosistemde yer alan hükümetlerin yaptırım ve etki gücü göz önüne alındığında, sistemlerin birey üzerindeki etkisi bireyin sistemler üzerindeki etkisine göre çok daha etkilidir (Genç vd., 2020; Tanhan, 2019). Çeşitli disiplinlerden birçok araştırmacı ve uygulayıcı, özellikle de halk sağlığı gibi yardım alanlarında, EST'den yararlanmıştır (Genç vd., 2020; Demir vd., 2017; Tanhan \& Francisco, 2019).

\section{Topluluk Temelli Katılımlı Araştırma (TeTKA)}

Yaşam kalitesini artırmak için sorunları (güçlük, mesele) veya mevcut kaynakları (avantaj, kolaylaştırıcılar) belirlemek amacıyla topluluklar ve ortaklar ile onlar için iş birliği yapmak ruh ve halk sağlığı müdahâle stratejilerinin önemli bir bileşenidir. Farklı araştırmacılar ortak/paydaş geliştirme (ally development; Tanhan \& Francisco; 2019; Tanhan \& Strack, 2020), topluluk temelli katılımlı araştırma (community-based participatory research; Tanhan vd., 2020), topluluk temelli aktif katılımlı araştırma (community-based participatory action research; Doyumğaç vd., 2020; Maiter vd., 2008), katılımcı/katılımlı eylem araştırması (participatory action research; Christensen vd., 2018; Minkler, 2000) ve okul-toplum ortaklığı (Doğan \& Julian, 2019) gibi çeşitli terminolojileri kullanmış olsalar da bu ifadeler, sorunları çözmek ve yaşam kalitesini daha etkin bir şekilde iyileştirmek için toplulukla topluluk için iş birliği yapma amacına işaret etmektedir. Araştırmacı bu çalışmada Topluluk Temelli Katılımlı Araştırma (Community-Based Participatory Action, CBPR) yani TeTKA kavramını okunması ve akılda tutulması rahat ve çalışmaya uygun olduğu için tercih etmiştir. TeTKA insanların meselelerini anlamak için yukarıdan aşağıya bir yaklaşımı reddeder. TeTKA araştırmacıların bireyler, gruplar, topluluklar ve kurumlarla müttefik olarak toplulukların sorunlarını çözmek ve iyi oluşlarına katkı sağlamak için iş birliği yapmasına dayalı alternatif bir araştırma paradigmasıdır (Tanhan \& Strack, 2020; WallerStein \& Duran, 2006). Bu yaklaşımın uygulamalarına bir örnek olarak Tanhan ve Strack (2020) OSF'yi kullanarak ABD'deki bir üniversitede öğrenci, akademisyen, memur, işçi ve bunların ailelerinden oluşan 118 kişiden oluşan bir toplulukla çalışmıştır. Benzer şekilde, Tanhan ve Francisco (2019) araştırmalarında ABD'de bulunan bir üniversitede öğrenci, akademisyen, işçi, memur ve bunların ailelerinden oluşan bir toplulukla çalışmıştır. Araştırmacılar (Tanhan \& Francisco, 2019; Tanhan \& Strack, 2020) 
çalıştıkları toplulukla hareket ederek bu insanların biyopsikososyal manevi ve ekonomik olarak hayatlarını kolaylaştıran ve zorlaştıran yönlerini incelemiştir. Kolaylaştırıcı faktörlerin artırılması ve yaşanan zorlukların en etkili şekilde ele alınması için araştırmacılar katılımcılarla beraber aktif sosyal savunuculuk yapmıştır ve önemli sonuçlar elde etmişlerdir. Aktif savunuculuk TeTKA ve OSF'nin alt temelini oluşturan önemli bir kavramdır.

\section{Aktif Sosyal Savunuculuk}

Araştırmacılar biyopsikososyal manevi ve ekonomik açıdan bireysel, mikro, ekzo ve/ya makrosistem düzeylerde yaşanan adaletsizliği azaltmak için katılımcılarla ortak karar verme, öğrenme ve araştırmanın önemini vurgulamışlardır (Çiçek vd., 2020; Doyumğaç vd., 2020; Goodhart vd., 2006; Tanhan, 2019; Otanga vd., 2020; Tanhan \& Francisco, 2019; Yilmazli Trout vd., 2019). Beraber çalışma sonucunda elde edilen araştırma bulgularının ilgili ve yetkili kişi, kurum ve kuruluşlara iletilerek mevcut kaynakların artıılması ve yaşanan sorunların ele alınması yani aktif savunuculuğun rolüne vurgu yapılmıştır. Savunuculuk alanyazında aktif savunuculuk, sosyal savunuculuk, aktif sosyal savunuculuk veya sadece savunuculuk gibi farklı kavramlarla ifade edilmiş olsa da aynı anlama gelmektedir. Bu kavramlarla anlatılmak istenen araştırılan konu ile ilgili ve yetkili kişi, kurum ve kuruluşları araştırma hakkında bilgilendirerek yaşanan meseleleri ele almak ve genel iyilik hâlinin artırmaktır. Yani araştırmacılar gönüllü katılımcılar veya paydaşlarla araştırmayı sadece akademik bir düzeyde bırakmaz bağlamsal değişikliklerin oluşması için aktif olarak bir uğraşı verir. Mevcut araştırmanın yürütücüsü aktif sosyal savunuculuk kavramının diğer sadece savunuculuk veya sosyal savunuculuk kavramlarından daha olumlu ve kapsayıcı bir çağrışım yaptığını düşünerek bu araştırmada aktif sosyal savunuculuk kavramını kullanmıştır. Burada aktif sosyal savunuculuk şu anlamak gelmektedir: Araştırmacıların her bir bilimsel araştırma, konferans sunumu veya makaleleriyle akademik düzeyde yaptıkları savunuculuğun bir adım daha ötesine geçip araştırma sonuçlarını sadece bilimin rafları, laboratuvarları ya da kliniklerinde bırakıp ilgili kişi, kurum ve kuruluşların gelip kullanmasını beklemeden araştırmacı olarak ve katılımcılardan gönüllü olanlarla beraber sonuçları ilgili kişi, kurum ve kuruluşlarla mümkün tüm yüz yüze veya online yollarla paylaşarak toplumun var olan meselelerinin ele alınarak mümkünse çözülmesi ve mevcut genel iyilik halinin artırılması için uğraş vermesidir. Aşağıdaki kısımlarda aktif savunuculuk, sosyal savunuculuk veya sadece savunuculuktan maksat burada tanımlanan aktif sosyal savunuculuktur.

OSF'nin tümünün ve özellikle de önemli iki süreci oluşturan aktif sosyal savunuculuk ve TeTKA'nın daha kolay, eğlenceli ve etkili olması için araştırmacı OSF'de ele alacağı konuyu belirlemeye başladığı andan itibaren ilgili kişi, kurum ve kuruluşlardan gönüllü ve uygun olanları paydaş olarak sürece katabilir ve araştırmanın konusu, sorusu ve nasıl ele alınacağı gibi tüm süreçte başından beri bu uygun gönüllülerle çalışmaya başlayabilir. Ayrıca araştırmacılar OSF çalışmalarını diğer insanlara katılım için gönderdiğinde de yeni paydaşlar olarak katılmak isteyenler için paydaş olmanın ne demek olduğu, paydaşların ne yaptığı ve paydaş olmak için gereken temel prensipler gibi bilgilere araştırma formunda yer verip araştırmacıya nasıl ulaşacaklarını açıklayabilir. Böylece araştırmacı araştırmanın başında beraber başladığ 1 paydaşlardan başka farklı sayı ve zenginlikte paydaşlarla çalışma olasılı̆̆ını arttırabilir. Bu tüm paydaşların araştırmacı ve birbirleriyle iletişim kurabilmeleri için de uygun sanal ve gerçek iletişim platformları kurulabilir. Araştırma sürecinde paydaşların olması araştırmaya katılımı ve araştırmanın sonuçlarının bağlamsal gerçek hayatı da etkilemesi açısından oldukça önemlidir.

\section{Online Seslifoto (OSF)}

Tanhan ve Strack (2020) araştırmalarında daha fazla farklı ve katılımcıya ulaşarak daha etkili ve zengin araştırma yöntemi geliştirmek ve araştırmacı ve katılımcıların az zaman harcayarak anlamlı ve etki oranı güçlü sonuçlara ulaşmak için Online Seslifoto (OSF)'yi geliştirmiştir. Böylece OSF yöntem veya tekniği zaman ve maddi giderler vb. bağlamsal faktörler açısından daha yapılabilir hâle gelmiş ve pandemi, endemi, güvenlik sorunları, çatışma veya doğal afetlerden dolayı yüz yüze 
buluşmanın imkânsız veya çok zor olduğu durumlarda daha kullanışlı hale getirilmiştir. Bu araştırmacılar, Wang ve Burris'in (1997) geliştirdiği, geleneksel seslifoto yöntem/tekniğinden faydalanarak OSF'yi geliştirmiş̧ir. Literatürde araştırmacılar seslifotodan hem yöntem hem de teknik olarak bahsettiği için bu mevcut araştırmada iki terim birbirinin yerine kullanılmıştır. Geleneksel seslifotoda katılımcılar yüz yüze 8 ile 13 kişiden oluşan küçük gruplarda bir araya gelerek araştırmacıdan önce kısa bir eğitim alır. Daha sonra katılımcı fotoğraflarını çeker, fotoğraflarına eşlik edecek hikâyelerini yazar ve diğer katılımcı ve araştırmacı ile toplanarak fotoğraf ve hikâyelerini tüm grubun önünde paylaşır. Bunun bazı önemli avantajları vardır: Grupça bir araya gelip farklı hikâyelerin her gün birkaç saat derinlemesine dinlenilmesi, her katılımcının kendi hikâyesini anlatmak için yeterince zamana sahip olması ve katılımcıları empatik olarak dinlemede uzmanlaşmış araştırmacıların katılımcılarla zaman geçirmesi. Bu avantajların yanında geleneksel seslifoto yöntemi ciddi sınırlılıklar da içermektedir: Hem araştırmacı hem de katılımcılar açısından aşırı zaman gerektirmesi, anonim olmamas1, 8-13 gibi az sayıdan oluşan gruplardan oluşan katılımcıyla yapılabilmesi, ileri düzeyde uzmanlaşma ve araştırmacının fiziken katılımcıların ortamına sık sık gitmesini gerektirmesi ve genelde sorun oluşturan konulara odaklanılması. Ayrıca katılımcıların her oturum için zaman ayırması gerekliliği ve işlerinden geri kalması ve yüz yüze gelmenin zor olduğu COVID-19 gibi süreçlerde geleneksel seslifotoyu uygulamanın imkânsız olması da önemli bir sinıllılıtır. Bu yüzden Tanhan ve Strack (2020) araştırmalarında geleneksel seslifotonun avantajlarını da içeren ve sınırlılıklarını gideren OSF'yi geliştirerek birçok bağlama çok daha uygun inovatif bir teknik hâline getirmişlerdir.

Online Seslifoto (OSF)'nin üç temel amacı vardır. Birincisi insanların yaşamlarını biyopsikososyal, manevi, ekonomik ve bağlamsal olarak bütüncül bir açıdan kolaylaştıran ve zorlaştıran en önemli faktörleri katılımcıların kendi biricik perspektifinden ifade etmelerini sağlayarak katılımcıları güçlendirmek. Daha sonra katılımcılardan gönüllü olanlarla ve diğer paydaş olabilecek kişi ve kurumlarla iş birliği yaparak faktörleri analiz ederek yani anlaşılmalarını kolaylaştırmak için daha geniş gruplar altında kategorize ederek dönüştürücü ve kritik bir diyalog süreci başlatmaktır. İkincisi, pozitif psikoloji perspektifinden hareket ederek katılımcıların hayatlarını kolaylaştırmak; üçüncüsü psikopatoloji perspektifinden hareket ederek katılımcıların hayatını zorlaştıran faktörleri gönüllü katılımcı veya paydaşlarla birlikte analiz ettikten sonra sonuçlarını bağlama uygun gerçek veya sanal ortam etkinliği (örn., yemekli sergi, toplantı, konferans, rapor, sempozyum ve sanal medya) gibi yollarla gönüllü katılımcı ve paydaşlarla beraber ilgili ve yetkili kişi, kurum ve kuruluşlarla paylaşarak aktif sosyal savunuculuk yapmak. Bu aktif savunuculuğun temel amacı kolaylaştırıcıları ihtiyaç düzeyinde artırmak ve meselelerin etkili şekilde ele alınması ve çözüme kavuşturulması için mevcut genel iyi oluş düzeyini yükseltmektir.

Özetle OSF birey ve toplum düzeyinde genel iyilik hâlinin artırılması ve var olan meselelerin en etkili şekilde ele alınması için nitel araştırma yöntemlerinden/tekniklerinden birisidir. OSF yöntemi gönüllü katılımcılar ve ilgili kişi, kurum kuruluşlarla iş birliği yapıldığında yani TeTKA, EST ve aktif sosyal savunuculuk bağlamında kullanıldığında bağlamsal olarak daha etkili sonuçlar vermektedir. Dolayısıyla katılımcıları ve katılımcıların içinde yaşadığı toplulukları güçlendirdiği, katılımcıların kaynaklarını artırdığ 1 ve yaşanan problemlerin daha işlevsel bir şekilde ele alındığı görülmüştür (Tanhan \& Strack, 2020). COVID-19 sürecindeki araştırmaların sinırlılıkları ve mevcut araştırmanın yukarıda açıklanan amaçları ve teorik çerçevesi düşünüldügünde araştırma alanyazına özgün bir değer katmıştır.

\section{Yöntem}

Araştırmada COVID-19 sürecinde üniversiteli öğrencilerin daha etkili ve bütüncül şekilde biyopsikososyal manevi ve ekonomik açıdan hayatlarını kolaylaştıran ve zorlaştıran faktörlerin anlaşılması için yukarıda ifade edilen teorik çerçeve kullanılmıştır. EST, TeTKA ve OSF COVID19 sürecinde düşünüldüğünde Tanhan ve Strack (2020)'in önerdiği gibi OSF'de bazı değisşiklikler 
yapılmıştır. Örneğin, yazarlar OSF analizleri bittiğinde gönüllü katılımcı, ilgili paydaş, kişi, kurum, kuruluş ve yerel ve ulusal medyanın davet edildiği herkese açık çok kültürlü ve manevi yani bağlamsal şartların da iyice düşünüldüğü ve katılımcıların anonim olarak gönderdiği fotoğrafların, fotoğraflara eşlik eden hikâye/yorumların ve temaların sergilendiği yemekli bir etkinliği vurgulayarak önermişlerdir. Çok kültürlülügün daha etkili ruh sağlığı hizmeti vermede oldukça önemli olduğunu başka araştırmacılar da belirtmişlerdir (Akkurt vd., 2018; Kağnıcı, 2012).

$\mathrm{Bu}$ etkinlikte katılımcılar isterse kendi kimliklerini saklamaz ve açıktan kendi veya başkasının fotoğraf, hikâye ve temalarının yanında durarak hikâyeyi sergiye/etkinliğe gelen diğer kişiler ile daha da derin bir şekilde paylaşabilir. Böylece OSF katılımcıları ve ilgili diğer kişi, kurum ve kuruluş koordinatörleri hem sergi hem de yemek sürecinde ortamdaki anlamlı kritik diyaloğa katkı yapabilir. COVID-19 sürecinde fiziki mesafe hayati önem taşıdı̆̆ından fiziki yüz yüze ve yemekli sergi/etkinlik, en azından şimdilik yapılamamış, ancak yine Tanhan ve Strack (2020)'in araştırmalarında önerildiği gibi araştırmanın dizaynı ve sürdürülmesinin yanı sıra sonuçlarının duyurulması, kritik ve anlamlı diyalogların oluşması için bütün araştırmanın süreci tamamen online yapılmıştır. Araştırmacıların OSF'yi kullanırken daha etkili sonuçlar için bu mevcut araştırmada olduğu gibi bağlamsal faktörlere dikkat etmeleri gerekir.

\section{Katılımcilar}

Bu araştırmaya Türkiye'nin doğusundaki bir üniversitede okuyan toplamda 148 üniversite öğrencisi katılırken bunlardan sadece 127 (56 erkek, 70 kadın ve 1 kişi belirtmek istememiştir) kişi nihai örneklemi oluşturup verilerinin araştırma için kullanılması için izin vermiştir. Yirmi bir kişi ise araştırmayı merak ettiklerinden katıldıklarını ifade etmiş ve verilerinin bilimsel araştırma için kullanılmasına izin vermediğinden, yani elektronik formda "fotoğraf, hikâye ve temamın hiçbir şekilde araştırma için kullanılmasını istemiyorum" kutucuğunu seçtiği için bu araştırmaya dâhil edilmemiştir. Araştırmacı pilot çalışmalar için oldukça uygun olan seçkisiz olmayan örnekleme yöntemlerinden uygun örneklemeyi seçmiştir. Araştırmacı, araştırma linkini gönüllü bir şekilde ruh sağlığı araştırmaları ve hizmetlerine öncülük ettiği, üniversite altında yer alan ve Psikolojik Danışmanlık ve Rehberlik (PDR) Ana Bilim Dalı (ABD) altında yer alan psikolojik danışmanlık biriminden (klinik) hizmet alan kişilere göndermiştir. Klinikten üniversitedeki herkes faydalanabilmekle beraber faydalananların hemen hemen hepsi öğrenciler olmaktadır. Araştırmacı OPV'nin Türkçe versiyonunun geliştirilmesi ve COVID-19 sürecinde kullanılmasının anlaşılabilmesi için araştırmanın pilot çalışma olduğunu söylemiştir. Bu yüzden de araştırma linkinin diğer insanlara iletilmemesini istemiştir. Linki 550 kişiden fazla kişi tarafindan görüntülendiği (tıklandığı) düşünülmektedir. 127 katılımcıdan 117 kişi araştırmaya online form üzerinden katılırken 10 katılımcı araştırmaya link üzerinden katılamadığını söyleyip araştırma sorularına olan cevaplarını e-posta üzerinden araştırmacıya ulaştırarak katılmışlardır. Hem OSF hem de geleneksel seslifotoda zor durumda kalan ve katılmak isteyenlerin yer alması için uygun tüm yolların kullanılması kullanılan teorik çerçeve ve hedeflenen temel amaçlar açısından çok önemlidir. Araştırma tamamen online yapılmış olup, araştırma linki araştırmacının ve arkadaşlarının sanal medya hesapları ve psikolojik danışma hizmetleri ve araştırmalarını yürüttüğü psikolojik danışma biriminin e-posta sistemi ve sanal hesapları üzerinden duyurulmuştur. Araştırmada linkin açılmaması durumunda katılımcıların araştırmacıya e-posta üzerinden de ulaşabileceği ve katılabilecekleri söylenmiştir. Katılımcılara ait diğer bazı demografik veriler şöyledir: 127 öğrenci 10 farklı fakülteden katıldığını bunlardan bir kısmı ise mezun olup pedagojik formasyon için üniversitede eğitim aldıklarını belirtmiştir. COVID-19 sürecini 75 katılımcı bahçeli ve 57 kişi bahçesiz ev/apartmanda geçirdiğini belirtmiştir. Katılımcılar bu pandemi sürecinde yaşadıkları ev için her iki seçeneği de tercih edebilmiştir. Sosyoekonomik açıdan 35 kişi düşük, 82 kişi orta ve 10 kişi durumlarını yüksek olarak belirtmiş; medeni durum açısından 115 kişi bekâr ve 12 kişi evli olduğunu ifade etmiştir. 


\section{Süreç}

Tanhan vd. (2020) bir COVID-19 araştırmasında Türkiye'nin doğusundaki bir üniversitede okuyan üniversiteli öğrencilerin biyopsikososyal manevi ve ekonomik meselelerden hafif, orta ve ağır bir şekilde yakındığını bulmuştur. Bu araştırmacılar genel olarak Türkiye ve özel olarak da Türkiye'nin doğusundaki üniversiteli öğrencilerin COVID-19 sürecindeki biyopsikososyal manevi ve ekonomik durumlarının katılımcıların kendi perspektiflerinden anlaşılması ve meselelerin çözüme kavuşturulması için inovatif bir teknik olan OSF'nin kullanılmasını önermişlerdir. Bundan dolayı araştırmacı öncelikle OSF'nin Türkçeye İngilizceden uyarlanıp uyarlanmadığını veya OSF'nin farklı isimler altında Türkçe olarak kullanılıp kullanılmadığını anlamak için kapsamlı bir literatür taraması yapmıştır. Araştırmacı ayrıca genel olarak COVID-19 sürecinde yapılan bilimsel çalışmaları ve özelde de üniversitelilerin ruh sağlığı üstüne yapılan çalışmaları incelemiştir. Tüm bunların üstüne araştırmacı yukarıda sayılan literatürdeki boşlukları gidermek ve yapılan önerilere cevap vermek için bu araştırmanın etik kurul iznini almıştır. Araştırmacının ruh sağlığı araştırmalarına ve hizmetlerine öncülük ettiği üniversitede yer alan klinikten hizmet alan veya klinikte hizmet sağlayan birkaç öğrenci ve akademisyen bu çalışmada ilk gönüllü paydaşlar olmuştur. Bu paydaşlar ve daha sonraki gönüllü paydaşlarla araştırmanın teorik çerçevesi oluşturulmuş ve süreç boyunca da bağlama uyması için araştırma şekillendirilmiştir. Araştırma linki bu paydaşlar yoluyla klinikten hizmet alan kişilere ulaşılması için bireysel ve sanal/sosyal medya üzerinden duyurulmuştur. Araştırma COVID-19 sürecinden dolayı tamamen online yapılmıştır. Araştırmayı duyan, klinikten hizmet alan ya da sağlayan ve araştırmacıyı tanıyan bazı öğrenciler ve akademisyenler de bu süreçte gönüllü olmuş böylece araştırmanın teorik çerçevesinde önemli bir basamak olan paydaş sürecini oluşturmuşlardır. Araştırmanın teorik çerçevesi (COVID-19 sürecinde OSF'yi EST bağlamında TeTKA ile kullanma) gereği gönüllü katılımcılarla araştırmayı sürdürmek OSF araştırmalarını zenginleştiren ve anlamlandıran en önemli basamaklardan birisidir. Bu paydaşlarla WhatsApp gibi akıllı telefon uygulamaları, e-posta ve Facebook gibi sanal medya grupları üzerinden gruplar kurulmuş ve iletişim bu yollarla sağlanmıştır. Ayrıca sonuçların herkese açık olacağı bir Facebook grubu ve sayfası hesabı da açılmış ve katılımcılara linki verilmiştir. Araştırmanın akademik makaleye dönüştürülmesi hariç, söz konusu paydaşlar tüm araştırma sürecine başından sonuna kadar aktif olarak katılmıştır. Paydaşlardan bazıları da makalenin son hâlini okuyarak geri bildirim vermiş ve yazar bu geribildirimlere göre makaleyi düzenlemiştir.

\section{Veri Toplama Araçları}

$\mathrm{Bu}$ araştırmada araştırmacı etik izin bilgisi ve demografik soruları içeren bir form, araştırmacının OSF tekniğini açıkladığı bir video, bu videonun sadece ses kaydından oluşan bir M4A, videoda anlatılanları yazı dili ile açıklayan bir doküman ve son olarak özellikle de çalışmanın sonuçlarıyla ilgilenecek herkese açik olan bir sanal/sosyal medya grubunu kurarak bunların hepsini katılımcılara sunmuştur. Bu dokümanların hepsi katılımcılara gönderilen online formda toplanmıştır.

Araştırma ve Etik İzin Bilgilendirme/Onam Formu. Katılımcılara araştırmanın etik izninin alındığ 1 bilgisini ve araştırmaya katıldıklarında verilerinin araştırma için kullanıp kullanmama konusunda izinlerine dair sorular içeren bilgilendirilmiş/onam formu sunulmuştur. Araştırmaya merakl1, istekli veya hikâyesinin sadece araştırmacı tarafından duyulmasını isteyen katılımcılar araştırmaya katılıp "gönderdiğim fotoğraf, hikâye ve temanın araştırma için kullanılmasını istemiyorum" seçeneğini işaretleyebilmiştir.

Demografik Bilgi Formu. Bu formda katılımciya cinsiyet, medeni ve sosyoekonomik (SES) durum ve COVID-19 sürecinde yaşadıkları konutun bahçeli veya bahçesiz ev/apartman olup olmadığı sorulmuştur.

OSF'yi ve OSF'ye Katılımı Açıklayan Video. Araştırmacı katılımcılar ve araştırmacılar için OSF'nin (1) ne demek olduğunu ve (2) OSF'ye katılımı kolaylaştırmak, artırmak ve eğlenceli hâle getirmek için detaylıca bilgi içeren bir video hazırlamıştır. COVID-19 süreci ve diğer bağlamsal 
faktörlerden dolayı videonun olması çok önemli olmuştur çünkü hem Türkçede ilk defa kullanılan hem de biraz farklı bir yöntem olması nedeniyle görsel ve işitsel duyulara seslenen bu tanıtıcı ve kolaylaştırıcı doküman araştırmanın teorik çerçevesine de oldukça uygun olmuştur.

Araştırmacı bu araştırmada ve ilerideki tüm OSF araştırmalarında araştırmacı, katılımcı ve bu konu ile ilgilenen herkesin faydalanması için Türkçe ve İngilizce iki video hazırlamıştır. Türkçe videoya https://www.youtube.com/watch? $v=\_e 0 i m J T t C \_Y$ ve İngilizce videoya https://www.youtube.com/watch?v=ArqgA33EMDQ linklerinden ulaş1labilir.

OSF'yi ve OSF'ye Katılımı Açıklayan M4A. Araştırmacı ve paydaşlar araştırmanın teorik çerçevesinin gerektirdiği gibi COVID-19 ve katılımcıların katıldığ 1 üniversitedeki birçok öğrencinin sosyoekonomik bağlamında zorlanacağını düşünmüștür. Bundan dolayı öğrencilerin sahip olacağı sınırlı internet kaynakları düşünülerek yukarıda açıklanan OSF videosunu M4A'ya çevirerek çok daha az internet gerektiren bir M4A'yı kullanıma açmıştır. Bu şekilde sınırlı internet kaynakları olan katılımcılar veya görme noktasında zorluk yaşayanlar M4A'yı tercih edebilmişlerdir. M4A katılımcının araştırma videosunu tekrar izleyerek zaman ve internet kapasitesi kaybı gibi dezavantajları yerine M4A'yı online veya indirerek dinlemesi için önemli bir araç olmuştur.

Araștırmacı yukarıdaki videoları Türkçe ve İngilizce olarak ses kaydına çevirmiş ve bu çalışmanın katılımcılarına, gelecekteki araştırmacılara ve bu konu ile ilgilenen herkesin kullanımına açmıştır. Ses kaydına bu linkten ulaşılabilir: Türkçe versiyonu için https://drive.google.com/drive/folders/1EDjhalb5gy_iJJXMahLR1Ye9qe1OiVy7?usp=sharing ve İngilizce versiyonu için https://drive.google.com/drive/folders/1wtq6s4KU6zHR2uHU7ww9HJweYY_B3UiQ?usp=sharin $\mathrm{g}$

OSF'yi ve OSF'ye Katılımı Açıklayan Yazı Dili belgesi. Yukarıda anlatılan OSF videosundaki her şey PDF ve Microsoft Word ve PPT dokümanları şeklinde yazı dili ile de ifade edilmiştir. Bunların hepsinin sağlanmasının temel amacı katılımı eğlenceli hâle getirmek, kolaylaştırmak ve farklı birçok katılımcıya ulaşarak COVID-19 sürecinde hem katılımı artırmak hem de katılımcılara anlamlı bir araştırma süreci yaşatmaktır. Ayrıca tüm bu yolların kullanılmasının temel bir sebebi de farklı noktalarda zorluk yaşayan (örn., işitme, görme, sınırlı internet) ve araştırmaya katılmak isteyen kişilere katılımı kolaylaştırmaktır. $\mathrm{Bu}$ da araştırmamızın teorik çerçevesine ve araştırmada gönüllü olan paydaşlarımızın onayına uygun olarak yapılmıştır.

Araştırmacı yukarıdaki videoları Türkçe ve İngilizce olarak ses kaydına çevirmiş ve bu çalışmanın katılımcılarına, gelecekteki araştırmacılara ve bu konu ile ilgilenen herkesin kullanımına açmıştır. Ses kaydına aşağıdaki linklerden ulaşılabilir. Türkçe versiyonu için https://drive.google.com/drive/folders/1EDjhalb5gy_iJJXMahLR1Ye9qe1OiVy7?usp=sharing ve İngilizce versiyonu için https://drive.google.com/drive/folders/1wtq6s4KU6zHR2uHU7ww9HJweYY_B3UiQ?usp=sharin $\mathrm{g}$

Birçok araştırmacı eğitim ve ruh sağlığı araştırmalarında ve uygulamalarında bağlamsal koşulların düşünülmesini ve elektronik cihazlara sahip olamayan kişilere bunların daimî veya geçici olarak temin edilmesini özellikle vurgulamışlardır (Tanhan \& Francisco, 2020; Tanhan \& Strack, 2020). Bu araştırmacılar kendi araştırmalarında katılımcılara geçici olarak elektronik cihaz temin etmişlerdir. Mevcut araştırmada en başta COVID-19 süreci ve araştırmacının görev yaptığ üniversitedeki maddi imkânların yetersizliği nedeniyle katılımcılara katılım için gereken hiçbir cihaz sağlanmamış olup katılım için elektronik cihaz talebi gelmemiştir.

Sanal/Sosyal Medya Platformu: Tüm bunlara ek olarak, araştırmacı katılımcıların, gelecekteki araştırmacıların ve OSF'ye veya OSF çalışmalarının sonuçlarıyla ilgilenen herkesin katılabileceği ve daha kritik ve anlamlı diyaloglar ve iş birliği geliştireceği bir Facebook grubu ve 


sayfası kurmuş ve linkini de çalışmada katılımcılara sağlamıştır:
https://www.facebook.com/groups/OPV.OSF.Online.Photovoice.Seslifoto (Facebook grubu) ve https://www.facebook.com/OnlinePhotovoiceOPV (Facebook sayfasi).

\section{Online Seslifoto (OSF) Basamakları}

Tanhan ve Strack (2020)'in araştırmasında birçok katılımcı OSF'yi ilgi çekici ve eğlendirici bulup işlevsel bir teknik olan OSF'nin geleneksel olarak yüz yüze olmasından ziyade online olarak yapılmasını ve araştırmanın basamaklarının tek tek yazı dili ile açıklanmasını önemli ve araştırmaya katılımı kolaylaştırıcı bulduklarını ifade etmişlerdir. Bu yüzden söz konusu araştırmada yukarıdaki dokümanlarda ifade edilen OSF bilgi ve basamakları aşağıda açıklanmıştır.

Katılımcılara OSF'nin kimler tarafından geliştirildiği ve OSF'nin temel amacının ne olduğu açıklanmıştır. Daha sonra katılımcılar COVID-19 sürecinde hayatlarını kolaylaştıran en önemli kolaylaştırıcı ve zorlaştırıcı faktörü sırasıyla OSF yoluyla diğer insanlarla paylaşmaları için aşağıdaki tüm basamakları tamamlamıştır. Katılımcı daha sonra aynı basamakları zorlaştırıcı faktör için hazırlanan bölüme geçerek tamamlamıştır. Böylece katılımcı önce zorlu pandemi sürecinde pozitif ve hoşa giden faktörleri hatırlamakta sonra hoş olmayan faktörlere odaklanmaktadır. Başka araştırmacılar da önce hoşa giden sonra hoşa gitmeyen faktörlere odaklanmayı önermişlerdir (Tanhan \& Francisco, 2019; Tanhan \& Strack, 2020). Bu makalenin daha öz olması için, araştırma formunda kolaylaştırıcı ve zorlaştırıcı faktörler için ayrı ayrı iki kez ele alınan OSF'nin aşağıdaki beş basamağı bu makalede sadece bir kez ele alınmıştır.

Adım 1: COVID-19 sürecinde hayatı kolaylaştıran ve zorlaştıran faktörleri düşünmek ve en önemli kolaylaştırıcı ve zorlaştırıcı faktöre karar vermek. Bu adımda katılımcılardan COVID-19 sürecini ve kendileri veya yakın hissettikleri kişiler için hayatı kolaylaştıran ve zorlaştıran en önemli faktörleri düşünmeleri istenmiştir. Katılımcılara bu faktörleri zihinlerinde tutabilecekleri söylenmiş ancak daha rahat ve etkili karar verme açısından ve katılım sürecinde internet kesintisi gibi aksaklık durumlarını da göz önünde bulundurarak bu faktörleri bir not defteri veya elektronik bir cihazda kaydetmelerinin daha güvenli olacağı önerilmiştir. Bu adımda önemli faktör sayısının en az bir en fazla 10 olacağ 1 söylenmiştir. Her bir faktör üstüne mindful yani kendinde (bilinçli bir farkındalıkla) düşünüp bunlardan en önemlisini seçerek bir sonraki adıma geçmeleri söylenmiştir.

Adım 2: En önemli kolaylaştırıcı ve zorlaştırıcı faktörü temsil edecek fotoğraf karesini almak. Bu adımda katılımcılar, bir önceki adımda belirledikleri en önemli faktörü temsil edecek fotoğraf kareleri çekmektedir. Katılımcı istediği kadar fotoğraf çekebilir ancak OSF'de kolaylaştırıcı ve zorlaştırıcı için sadece birer fotoğraf gönderebilir. Bir tane ile sınırlandırmanın birinci amacı, katılımcının en önemli faktöre odaklanmasını sağlamak; ikincisi amacı ise literatürde görülen analiz sürecinde analize dâhil edilmeyecek hem katılımcı hem de araştırmacı için zaman israfina neden olacak gereğinden fazla data toplanması gibi durumlardan kaçınmaktır (Tanhan \& Strack, 2020). Fotoğraf karesinin en önemli faktörü temsil edip etmediği katılımcının kendi düşünce, algılama, duygu ve o kareye yüklediği anlama bağlıdır. Yani dışarıdan başkası kareye baktığında en önemli faktörü net bir şekilde görmesi önemli değildir, önemli olan katılımcının o kareye yüklediği anlamdır. Ayrıca katılımcıları ve diğer insanları korumak, saygı duymak ve araştırmanın etik kurallarına uygun olması için fotoğrafta hiçbir insan yüzünün gözükmemesi önerilmiştir. Benzer şekilde özel mülkiyet, örneğin bir ev tamamıyla, başkaları tarafından tanınacak ve belirlenecek kadar fotoğrafa alınmamalıdır. Buna uymayan fotoğraflar uygun bir şekilde düzenlendikten sonra analize alınmıştır. Her adımda olduğu gibi bu adımda da katılımcılara fotoğraflarını direkt OSF online formuna yüklemek yerine daha kendinde ve anlamlı bir süreç ve katılım sürecinde olası internet sorunlarına karşın fotoğraflarını önce başka bir yerde saklamaları önerilmiş̧ir. Tüm bunlara ek olarak, COVID19'un zorlu pandemi bağlamı düşünüldüğünde, mevcut araştırmacı bazı katılımcıların internet sıkıntısı çektiğini (örn., yüksek düzeyde kaliteli ve çok yer kaplayan fotoğrafi düşük internet 
kapasitesiyle gönderememek, fotoğraf çekecek elektronik cihazın olmaması) bundan dolayı da internetten fotoğraf çektiği ya da indirdiğini düşünmektedir. Bazı katılımcılar bunu ifade etmişse de araştırmacı kaç kişinin böyle yaptığını bilmemektedir.

OSF'de katılımcılara kendi fotoğraflarını kendilerinin çekmesinin anlam ve avantajları anlatılmakla beraber katılımcı herkese açık olan ve başkasının hakkına ve gizliliğine yani hakkı saklıdır etik kurallarına uyarak internetten de fotoğraf kullanabilir. Bunun temel sebebi, imkânları olmayan ve araştırmacıların imkân sağlayamadığı veya ulaşamadığı kişilerin perspektifini susturmak ve bastırmak yerine bağlamsal şartlarda olabildiğince yer vermektir. Hem Tanhan ve Strack (2020) hem de mevcut çalışmanın araştırmacısı bu çalışmada sayıları net olarak bilinmese ve çok fazla olmasa da bazı katılımcıların internetten hazır fotoğraf kullandıklarını düşünmektedir. Mevcut çalışmanın yazarı bazı katılımcıların kamerası iyi olan bir cihaza sahip olmaması, dışarıya çıkmanın zor veya imkânsız olduğu (örn., COVID-19 sokağa çıkma yasakları ve dışarıya çımanın getireceği virüsün bulaşması tehlikesi) durumlarda bazı katılımcıların internetten hazır fotoğraf bulma, indirme ve kullanmaya yöneldiğini düşünmektedir. Mevcut çalışmadaki araştırmacı, bağlamsal şartlardan dolayı kendisi fotoğraf çekemeyen katılımcıların internetten ya da diğer insanlardan etik kurallara dikkat ederek fotoğraf bularak çalışmaya katılıp kendi perspektiflerini paylaşmalarını, bu katılımcıların tamamen katılmamalarından ve susmak zorunda kalmalarından, çok daha değerli olduğunu görmüştür. Bir takım imtiyaz (örn., zenginlik, şartlar, statü) sahibi ol(a)mayan bu katılımcıların katılımı hem araştırmanın hem de bireysel düzeyde katılımcı için biyopsikososyal manevi ve ekonomik açıdan büyük bir avantaj getirmektedir.

Adım 3: Kolaylaştırıcı ve zorlaştırıcı fotoğraflara eşlik edecek hikâyeyi/yorumu yazmak. OSF'de en önemli adımlardan birisi katılımcının kendi bakış açısıyla yazacağ 1 ve seçtiği fotoğrafa eşlik edecek hikâyesidir. Fotoğraf karesi tek başına çok şey anlatsa da asıl olan kareyle ilgili katılımcının kendi hikâyesi/yorumudur. Dolayısıyla fotoğrafı çok daha anlamlı ve zengin hâle getiren katılımcının yazdığı hikâyedir. OSF’nin temel amacı duyulmamış ve tam anlamıyla bilinmeyen yaşantı ve hikâyeleri diğer ilgili ve yetkili kişi, kurum ve kuruluşlara ileterek genel iyi oluş düzeyini yükseltmek ve yaşanan zorluk, sıkıntı ve problem gibi meseleleri ele almaktır. Bu yüzden katılımcı dışındaki diğer insanların katılımcının seçtiği fotoğrafa başka şeyler atfetmek yerine öncelikle katılımcının aktarmak istediği yaşantı, duygu, düşünce ve hisleri anlaması için fotoğrafa eşlik edecek hikâye/yorum çok önemlidir. Araştırmada katılımcı ve diğer insanları korumak, onlara saygı duymak ve araştırmanın etik kurallarına uygun olması için hikâyede tanınacak şekilde isim ve soy isim gibi şahsi bilgiler kullanmamıştır.

Tanhan ve Strack (2020) OSF'nin hikâye yazma basamağında katılımcıların rahat, eğlenerek ve daha anlamlı yorumlar yazmaları için Wang ve Burris (1997)'in seslifoto sorularının bazılarını değiştirmiş ve yeni bir soru da eklemiştir. Bu değişiklik OSF'yi başta ruh sağlı̆̆ olmak üzere tüm alanlarda kullanmaya daha elverişli hâle getirmiştir. Bu mevcut araştırmada Tanhan ve Strack (2020)'in kullandığı sorular OSF'nin orijinali korunarak Türkçe'ye çevrilmiştir. OSF'de hikâyenin temel amacı diğer insanların fotoğrafa ve hikâyeye katılımcıdan farklı ve özellikle de çok farklı bir anlam yüklemesini önlemek ve katılımcının hislerinin, duygularının, düşüncelerinin ve sesinin yani yaşamının anlaşılmasına aracı etmektir.

Bundan dolayı Tanhan ve Strack (2020)'in önerdiği altı OSF sorusunun katılımcı ve araştırmacılar tarafindan rahatlıkla hatırlanması için sorular dikkatlice Türkçeye çevrilmiş ve orijinalinde yapıldığı gibi bu altı sorunun anahtar kelimeleri seçilerek bir kısaltma yani akronim oluşturulmuştur. Araştırmacı ve paydaşlarla beraber bu kısaltmanın da GÖZSAN olarak adlandırılmasın karar verilmiștir. Buradaki temel amaç da katılımcı $\boldsymbol{G} \boldsymbol{O} Z \boldsymbol{Z S A N}$ sorularını takip ederek hikâyesini yazarsa başka $\boldsymbol{G} \ddot{O} Z$ ler fotoğrafi ve hikâyeyi kendi zihinsel sürecinden geçirerek başka şey SANmaz. Böylece katılımcı GÖZSAN sorularından faydalanarak çok daha rahat ve eğlenerek kendisine ve diğer insanlara aktarmak istediği daha etkili, öz ve anlamı bütün bir hikâye yazabilir. 
Aşağıdaki sorular bir araştırmada kullanıldığında ayrı ayrı önce kolaylaştırıcı sonra zorlaştırıcı faktör için sorulmalı ki katılımcı OSF basamaklarını daha rahat, anlayarak ve an'da olarak katılabilsin. Bu şekilde ayrı ayrı sormak araştırmacının veriyi daha sistematik, kolay, anlaşılır ve etkili bir şekilde yapmasını sağlar.

Katılımcının anlamlı, öz ve bütün bir hikâye için takip edeceği $\boldsymbol{G O ̈ Z S A N}$ soruları şöyledir:

G. Fotoğrafta COVID-19 sürecinde hayatını kolaylaştıran durum ile ilgili ne Görüyorsun?

Fotoğrafta COVID-19 sürecinde hayatını zorlaştıran durum ile ilgili ne Görüyorsun?

O. Fotoğrafta neler Oluyor (fotoğrafi kısaca anlat/betimle)?

$\underline{\mathbf{Z}}$. Fotoğrafta olanların sen/si $\underline{\mathbf{Z}}$ (bireysel veya yakın hissettiğin diğer insanlar) ile nasıl bir iliş̧isi var?

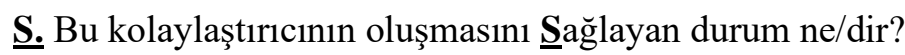

Bu zorlaştırıcıyı oluşturan $\underline{\text { Sebepler ne/nelerdir? }}$

A. Fotoğrafı alırken ve şu anda bunları yazarken ne yㅗsşıorsun (his, duygu, düşünce, davranış)?

‥ Bu faktör, fotoğraf, hikâye ve temayı beraber düşündüğünde bu konuda hepimiz, örn., ruh sağlığı uzmanları, akranlar, araştırma ve hizmet kuruluşları, yöneticiler ve diğerleri yaşam kalitesini artırmak ve var olan meseleleri etkili şekilde ele almak için $\underline{\mathbf{N}}$ yapabiliriz?

Yukarıda yer alan ikinci soruda "O" geçtiği hâlde akronimde "Ö" diye kodlanmasının temel amacı GOZSAN yerine GÖZSAN şeklinde telaffuzu ve akılda tutmayı kolaylaştırarak katılımcı ve araştırmacıları motive ederek daha anlamlı bütün hikâyeler oluşturmaktır. Katılımcılardan sorulara birbirinden ayrı ayrı ya da alt alta cevap/cümleler yazmak yerine tüm soruları kapsayacak ve geçişleri uygun şekilde olan anlamlı, kapsayıcı, öz ve bütün bir yorum yazmaları istenmektedir. Bu üçüncü adımda da katılımcının yazdığı hikâyenin, internette olası sorunların çıkması durumunda, hem kaybolmaması hem de daha anlamlı ve kendinde bir hikâye için katılımcının hikâyeyi önce başka bir yerde yazması, gözden geçirmesi ve en son hâlini forma yüklemesi önerilmiştir.

Adım 4: Tema/metafor: Bu adımda katılımcı, önce en önemli kolaylaştırıcı faktörü ve ona eşlik eden fotoğraf karesini ve hikâyeyi düşünür. Daha sonra katılımcı bunların hepsini özetleyen 10 kelimeyi geçmeyecek şekilde en az bir, en çok üç tema veya metafor belirler. Birden çok tema ya da metafor kullanan katılımcıdan mümkünse önce en önemli veya kapsayıcı olandan başlaması istenir. Katılımcı aynı şeyi en zorlaştırıcı faktör için de yapar. Tema veya metafor kullanımının üç amacı vardır. Birincisi, katılımcının kendi fotoğraf ve hikâyesinin özünü yani en üst anlamı çıkartmasına yardım etmek; ikincisi katılımcının aktarmak istediklerinin diğer insanların zihin ve kalplerinde etkili bir şekilde yer edinmesini hem kolaylaştırmak hem de daha uzun süre kalmasını sağlamak; analiz sürecinde üçüncüsü ise katılımcının bakış açısını korumak, tüm katılımcıların fotoğraf, hikâye ve temalarını ana gruplarda toplarken faydalanmaktır.

OSF’nin geleneksel seslifoto ve diğer birçok nitel araştırma tekniklerine göre katılımcının yaşantısını ve aktarmak istediği mesajı olabildiğince koruması açısından bu dördüncü basamak verinin analizinde OSF için olmazsa olmaz bir yer tutmakta ve OSF'yi diğer tekniklere göre daha avantajlı kılmaktadır. Araştırmacılar kendi araştırmalarında geleneksel Yorumlayıcı Fenomenolojik Analizi (YFA) yaklaşımını uyarlayarak Online Yorumlayıcı Fenomenolojik Analizi (OYFA) yaklaşımı şeklinde kullanmıştır. OYFA'yı da bu dördüncü adımı ekleyerek kullanmışlardır. Bu araştırmacılar geleneksel YFA'yı online kullanmış ama OYFA olarak adlandırmamışlardır. Bu mevcut araştırmada, geleneksel YFA ile OYFA'yı birbirinden ayırmak için "OYFA" kelimesi ilk defa kullanılmıştır. Bu da bu mevcut araştırmanın özgün değerini yükseltmekte ve OSF'nin amacı, kullanımını ve veri analizi sürecini daha anlaşılır kılmaktadır. Tanhan ve Strack (2020) OYFA'yı bu 
dördüncü adımı ekleyerek OSF verisinin analizinde kullanmak için araştırmacılara şiddetle önermişlerdir. Çünkü geleneksel seslifoto ve diğer birçok nitel yöntemlerde kullanılan geleneksel YFA sürecinde araştırmacılar, ilkin önce katılımcıları dinlemekte daha sonra ise senkronize yani görüşme anında veya daha sonra katılımcının ifade ettiği yaşantı, duygu, düşünce, his ve anlamdan hareketle katılımcıların yaşamları hakkında genel temalar çıkarmayı araştırmaktadır (Brunsden \& Goatcher, 2007; Smith \& Osborn, 2003; Tanhan \& Strack, 2020). Başka bir deyişle, geleneksel YFA kullanan araştırmacılar direkt katılımcıların sesinden ve yaşantısından ziyade ikinci basamakta araştırmacılar olarak kendi oluşturdukları temaları ön plana çıkarmaktadır. Bu da OSF’ye ters düşmektedir (Tanhan \& Strack, 2020) çünkü OSF'nin temel amacı baştan sona olabildiğince katılımcının yaşantısına ve kendisinin aktarmak istediği hikâye ve temaya ağırlık vermektir. Tanhan ve Strack (2020) OYFA'nın diğer geleneksel içerik (Brunsden \& Goatcher, 2007) ve anlatımsal (Harrison, 2002) analizden çok daha güçlü olduğunu da açıklamışlardır. Bütün bunlardan dolayı bu dördüncü basamakta OYFA kullanılmıştır.

Adım 5. En önemli faktörü Ekolojik Sistemler Teorisi (EST) Altındaki Sistem/lere Atfetmek. Tanhan ve Strack'in (2020) OSF araştırmasında beşinci adım olmamasına rağmen araştırmacılar sonraki araştırmacılara katılımcılara gönderdikleri kolaylaştırıcı ve zorlaştırıcı faktörleri temsil eden fotoğraf, hikâye ve temaları EST perspektifinden hangi sistem/lere atfettiklerini sorulmasını önermişlerdir. Bu yüzden mevcut araştırmaya bu beşinci adım eklenmiştir. $\mathrm{Bu}$ adımda katılımcılara araştırma için gönderdikleri kolaylaştırıcı faktör, fotoğraf, hikâye ve temayı EST'nin (1) bireysel/içsel (kişinin duygu, düşünce, davranış, tutum, cinsiyet, eğitim düzeyi gibi), (2) mikrosistem (aile, okul, akran, fiziki çevre, dini/manevi kaynaklar gibi), (3) ekzosistem (medya, komşular, sosyal hizmetler, yerel yönetimler, yerel kuruluşlar gibi) ve (4) makrosistemlerden (hükümetlerin politikaları, toplum değerleri, ekonomi, uluslararası kuruluşlar gibi) hangilerine atfettikleri sorulmuştur. Katılımcı yukarıdaki dört basamağı tamamladıktan hemen sonra bu beşinci adımdaki soruya cevap vermiştir. Aynı işlem zorlaştırıcı faktör için de takip edilmiş̧ir. Katılımcı birden fazla seçenek işaretleyebilmiştir. Bu araştırmada ilk defa kullanılan bu beşinci adım araştırmanın teorik çerçevesi (EST ve TeTKA bağlamında OSF) ile tamamen uyuşmakta ve araştırmaya özgün bir değer katmaktadır.

Katılımcılar veri analizi ve düzenlenmesinden sonra uygun gerçek ve sanal yollarla sonuçların ilgili kişi ve kurumlarla paylaşılacağı hakkında bilgilendirilmiştir. Ayrıca katılımcılara sonuçların hepsini görmek ve ilgili kişi ve kurumlarda aktif sosyal savunuculuk için araştırmacı ile hareket etmek isteyen ister araştırmaya katılsın ister katılmamış olsun herkesin araştırma için kurulan ve herkese açık olan sanal medya sayfasına araştırmada verilen linkten katılabilecekleri ifade edilmiştir. Tanhan ve Strack (2020) hem yüz yüze etkinliğin hem de sanal yolların kullanılmasını önermişlerdir. COVID-19 sürecinde fiziksel temasa azami dikkat edildiğinden bu araştırmada sonuçların sadece sanal yollarla ele alınacağı ve çok gerekirse ilgili kişi ve kurumlara araştırmacıyla beraber en fazla iki kişinin daha gideceği söylenmiştir. Bu durum da kullandığımız teorik çerçeveye yani bağlamsal şartlara göre araştırmaların düzenlenmesi fikrine uymaktadır.

\section{Verilerin Analiz Edilmesi}

Verilerin analizi sürecinde teorik çerçevenin perspektifine uyularak katılımcılardan ve konuya ilgili akademisyenlerden birkaç kişi araştırma süreci boyunca paydaş olmuş ve araştırmanın yazarı ile veri analizini de organize etmişlerdir. Mevcut araştırmada teorik çerçevenin önemli bir bileşeni olan OYFA'nın gerektirdiği gibi katılımcıların hikâyesini ve aktarmak istedikleri temaları korumak için veri analizinde sadece katılımcıların temaları kullanılııştır. Yani geleneksel YFA' dan farklı olarak Tanhan ve Strack (2020)'in adapte ettiği ve önerdiği şekliyle OYFA veri analizinde kullanılmıştır. Böylece veri analizi takımı katılımcıların temalarını benzer ana tema gruplarını oluşturmak için incelemiş ve her bir temayı uygun bir şekilde ana grupların altına yerleştirmiştir. $\mathrm{Bu}$ mevcut araştırmada veri analizi aşağıda ele alınan beş basamaktan oluşup ilk dört basamak Tanhan 
ve Strack (2020)'in araştırmasından küçük değişikliklerle alınmıştır. Yazarlar tarafından önerilen ama kullanılmayan beşinci basamak ilk defa bu araştırmada kullanılmıştır.

Adım 1: Fotoğraf, Hikâye ve Temaları Eksik Veri ve Onam İzni için İncelemek. Araştırmanın yürütücüsü önce boş gelen veya tekrarlanan verinin temizlenmesi için tüm verileri incelemiştir. Bundan sonra geriye kalan 148 yanıttan onam formunda "gönderdiğim fotoğraf, hikâye ve temamın araştırma için kullanılmasını istemiyorum" seçeneğini işaretleyen 21 katılımıının verisi silinmiştir. Bu 21 katılımcının çoğu, kendilerini veya diğer insanları fotoğraf karelerine almıştır. Ayrıca bazıları kendi deneyimlerini sadece araştırmacıya aktarmak istediklerini ve araştırmayı merak ettiklerinden katıldıklarını ifade etmișlerdir. OSF'de fotoğraf önemli olsa da daha önemli olan hikâye ve temadır bunun için fotoğraf gönder(e)meyen ama hikâye ve tema gönderen katılımcıların hikâye ve temaları analize dahil edilerek bir sonraki basamağa geçilmiştir.

Adım 2: Fotoğraf, Hikâye ve Temaları Kişisel Bilgi İçermesi Açısından İncelemek. Bu araştırmanın veri analiz takımı tüm fotoğraf, hikâye ve temalar başkaları tarafindan tanınacak şekilde şahsi insan ve mülkiyet bilgisi içerip içermediğini inceleyerek var olan şahsi isim, fotoğraf veya mülk gibi bilgilerin hepsini anonimleştirmiştir. Bunun temel amacı insanları korumak ve özel hayatlarına saygı duymaktır. Bazı araştırmacılar fotoğraflarında kendilerinin, ailelerinin veya diğer insanların yüzlerini ve şahsi bilgilerini paylaşmıştır. Bu yüzden araştırmacı insan yüzlerini fotoğrafların estetik görünümünü bozmayacak için papatya çiçekleri ile kapatmış ve özel bilgileri de [...] ile değiştirmiştir. Tüm katılımcıların fotoğraf, hikâye ve temalarının paylaşıldığı dosyada okuyucu bu değişiklikleri görebilir.

Adım 3: Kolaylaştırıcı Temaları Ana Temalar Altında Gruplamak. Bu adım iki alt adımdan oluşmaktadır. Birincisi, katılımcının hikâyesi ile verdiği tema/ların uyuşup uyuşmadığına bakmak. Elektronik hatalardan veya hikâye ve temayı önce başka yere yazma sonra online araştırma formuna kopyalama gibi katılım sürecinden dolayı çok nadir de olsa katılımcının yazdığı tema hikâye ile kısmen ya da tamamen uyuşmayabilir veya katılımeı temayı yazmayı tamamen unutabilmektedir. Böyle durumlarda OSF'nin temel amacı olan katılımcıların aktarmak istediğini olabildiğince olduğu gibi aktarmak için araştırmacılar fotoğraf ve hikâyeleri analiz etmez ve tema çıkarmaz (Tanhan \& Strack, 2020). Bunun yerine OSF ve OYFA kullanan Tanhan ve Strack "Diğer" başlıklı bir ana tema oluşturmuş ve teması olmayan fotoğraf ve hikâyeleri bu ana başlık altında toplamıştır. Bu mevcut araştırmada da teması olmayan hikâyeler "Diğer" başlıklı ana temada toplanmıștır. İkincisi ise tüm kolaylaştırıcı faktörlere ait benzer temalar uygun ana temalar altında organize edilmiştir. Birden fazla tema yazan veya teması birden fazla ana tema ile ilişkili olan fotoğraf, hikâye ve temalar en fazla üç ana temanın altına gruplandırılmışıı. OSF'nin en fazla vurguladığı katılımcıların aktarmak istediği yaşantı ve anlam olabildiğince olduğu gibi korunmuștur. OSF'nin temel amaçlarından biri olan katılımcıların aktarmak istediği hikâye ve temayı korumak için en az üç katılımcının bahsettiği temalar, ana tema olarak kabul edilmiş başka benzer bir temayla birleştirilmemiştir.

Katılımcının yazdığ 1 temanın tam olarak hangi ana temaya yerleştirilmesi gerektiği anlaşılmadığında (örn., "karanlıktan 1şık doğar; mürekkebin akmadığı yerde kan akar") veri analizini yapanlar katılımcının hikâyesini öz bir şekilde okuyarak temayı katılımcının anlatmak istediği ana temaya olabildiğince yerleştirmiştir. Bulgular kısmında da görüleceği gibi kolaylaştırıcı (Tablo 1) ve zorlaştırıcı (Tablo 2) ana temalar için ayrı iki liste oluşturulmuştur.

Adım 4: Zorlaştırıcı Temaları Ana Temalar Altında Gruplamak. Bu adımda üçüncü adımdaki süreç izlenerek tüm benzer zorlaştırıcı temalar, uygun ana temalar adı altında sinıflandırılmıștır.

Adım 5: Kolaylaştırıcı ve Zorlaştırıcı Temaların EST Sistemlerinden Hangisine Atfedildiğini İncelemek. OSF’ye katılımın beşinci basamağında katılımcı en önemli kolaylaştırıcı ve zorlaştırıcı faktörü ayrı ayrı olarak EST'nin hangi (bireysel/içsel faktörler; mikro, mezo, ekzo, ve makro) sistem/lerine atfettiğini çoktan seçmeli bir soruda cevaplamıştır. Tanhan ve Strack (2020) ilk 
olarak araştırmacıların, katılımcıların atfetmesine bakmaksızın, hikâyeleri tek tek okuyup EST sistemleri altında sınıflandırmasını, daha sonra da bu bağımsız sonuçların katılımcıların atfetmesi ile de karşılaş̧ırılmasını önermişlerdir. Ancak mevcut araştırmanın teorik çerçevesi (OSF, OYFA, EST, TeTKA), yani katılımcıların yaşantı ve perspektifinin olabildiğince korunarak aktarılması ana amacı düşünüldüğünden bu araştırmada ve adımda sadece katılımcıların atfetmesine odaklanılmıştır. Buna ilişkin sonuçlar aşağıda bulgular kısmında Tablo 3'te katılımcıların seçme oranına göre yüzdelik olarak gösterilmiştir.

Tüm bunlarla beraber çok sistematik olmamasına rağmen veri analizi takımı, sonraki araştırmalara 1ş1k tutması için, birçok hikâyeyi beraber okumuş ve EST'nin hangi sistemlerine atfedilebileceğini ele almış ve daha sonra katılımcının atfetmesi ile karşılaştırmıştır. Katılımcıların çok büyük çoğunluğu hikâyelerini doğru sistem/lere atfederken önemli bir kısmı şu noktayı atlamış gibi gözükmektedir: Hikâyelerinde makrosistemlerden bahsetmiş ama OSF'ye katılım bölümündeki beşinci adım/soruda hikâyeyi makrosistemlerden ziyade diğer alt sistemlere, özellikle de bireysel/içsel sistemlere atfetmişlerdir.

Veri analizi sürecindeki bu beşinci adım aslında üçüncü ve dördüncü adımla da birleştirilebilir. Ancak şu dört temel nedenden dolayı bu beşinci adım veri analizine de ayrı bir adım olarak eklenmiştir. (1) Bazı araştırmacılar EST'yi kullanmak istemeyebilir. (2) OSF’yi özellikle de eğitim düzeyi düşük olan katılımcılarla kullanırken bu basamağın kullanılması çok uygun olmayabilir. (3) İlerideki araştırmacılar yukarıda anlatılan önce katılımcılardan bağımsız bir şekilde hikâyeleri okuma ve EST sistemlerine atfettikten sonra katılımcıların atfetmesi ile karşılaştırarak daha detaylıca ele almak isteyebilir. Son olarak (4) tüm bunları yani veri analizi sürecini araştırmacı, katılımcı ve okuyucular için daha anlaşılır ve saydam yapmak ve OSF'ye katılım ile OSF verisinin analiz süreçlerinin benzer şekilde ilerlemesini sağlamak için bu beşinci adım veri analizinde diğer adımlarla birleştirmek yerine ayrı bir adım olarak ele alınmıştır.

\section{Bulgular}

Yukarıda ifade edilen veri analiz basamakları takip edilerek analize dâhil edilmemesi gereken veriler silindikten sonra analizler yapılıp aşağıda dört başlık altında sınıflandırılan temel bulgulara ulaşılmıştır.

\section{COVID-19 Sürecinde Hayatı Kolaylaştıran Faktörlerin Ana Temaları}

COVID-19 sürecinde 127 katılımcının kolaylaştırıcı temalarına bağlı olarak 19 ana kolaylaştırıcı tema oluşmuştur. Tablo 1'de gösterilen ana temalar bir sonraki bölüm olan tartışma kısmında alanyazınla karşılaştırılmış ve detaylıca ele alınmıştır. Mevcut araştırmada kelime ve yer kısıtlılığından dolayı kolaylaştırıcı ve zorlaştırıcı ana temalar için sadece üçer farklı katılımcının fotoğraf, hikâye ve temaları seçilmiş olup bunlar da tartışma kısmında ana temalarla uyumlu olacak şekilde yer almıştır. Diğer tüm katılımcıların anonim fotoğraf, hikâye ve temalarına araştırma için kurulan şu adresten https://drive.google.com/drive/folders/1YLf334cpI9aw1wN0ej3CzFOwioj2EEyF?usp=sharing veya yazara e-posta atılarak ulaşılabilir. 
Tablo 1: Kolaylaștırıcı Faktör Ana Temaları

\begin{tabular}{|c|c|c|}
\hline Kolaylaştırıcı ana temalar & $\%$ & $\begin{array}{c}\text { Toplam kişi } \\
\text { (127) }\end{array}$ \\
\hline 1. An'da, kendinde, farkında olma; mindfulness; kendini dinleme & 33 & 42 \\
\hline 2. Aile, akraba, arkadaş ve yakın çevre ilişkileri & 18 & 23 \\
\hline $\begin{array}{l}\text { 3. Maneviyat/spiritüalizm: aşkınlık, sabır, şükür, din, nimet, namaz, ibadet, } \\
\text { ritüeller, umut, ümit }\end{array}$ & 18 & 23 \\
\hline 4. Doğa: bahçe, köy, hayvan, bitki, toprak & 17 & 21 \\
\hline 5. Sanat: resim, müzik, film, video & 13 & 17 \\
\hline 6. Kitap okuma & 12 & 15 \\
\hline 7. Anlam/mana arayıșı & 12 & 15 \\
\hline 8. Kendini geliştirme: yeni şeyler öğrenme & 11 & 14 \\
\hline 9. Online/uzaktan eğitim: teknoloji, bilgisayar, internet, telefon & 10 & 13 \\
\hline 10. Diğerlerine iyilik: yardım etmek, tebessüm etmek, empati kurma, üretmek & 9 & 12 \\
\hline 11. Sosyoekonomik durumun iyi olması & 6 & 7 \\
\hline 12. Kurum ve kuruluşlar (Sağlık Bakanlı̆̆ı, MEB, YÖK) & 5 & 6 \\
\hline 13. Plan/program yapmak & 4 & 5 \\
\hline $\begin{array}{l}\text { 14. Profesyonel ruh sağlığı hizmetleri: psikolojik danışmanlık, okuma-tefekkür } \\
\text { etme-paylaşma bibliyoterapi }\end{array}$ & 4 & 5 \\
\hline 15. Sağlıklı beslenmek ve hoșa giden yemekler yapmak & 4 & 5 \\
\hline 16. Egzersiz/spor yapmak & 3 & 4 \\
\hline 17. Akademide hocaların empatik davranması & 2 & 3 \\
\hline 18. Aile ile değil tek başına ya da arkadaşlarla yaşamak & 2 & 3 \\
\hline 19. Diğer: katılımcı tarafindan tema verilmeyenler & 11 & 14 \\
\hline
\end{tabular}

\section{COVID-19 Sürecinde Hayatı Zorlaştıran Faktörlerin Ana Temaları}

Zorlaştırıcı faktörler için 21 ana tema ortaya çıkmıştır. Tablo 2'de gösterilen bulgular tartışma kısmında alanyazınla karşılaştırılarak ayrıntılı olarak ele alınmıştır. Ana temaları temsili olarak üç katılımcının fotoğraf, hikâye ve temaları tartışma kısmında ana temalar ve ilgili alanyazınla uyumlu olacak şekilde paylaşılmıştır. Tüm katılımcıların anonim fotoğraf, hikâye ve temalarına araştırma için kurulan şu adresten https://drive.google.com/drive/folders/1 YLf334cpI9aw1wN0ej3CzFOwioj2EEyF?usp=sharing veya yazara e-posta atılarak ulaşılabilir. 
Tablo 2: Zorlaştırıcı Faktör Ana Temaları

\begin{tabular}{|c|c|c|}
\hline Zorlaștırıcı ana temalar & $\%$ & $\begin{array}{c}\text { Toplam kişi } \\
\text { (127) }\end{array}$ \\
\hline 1. Aile, akraba, arkadaş ve sevilenlerle fiziki olarak beraber olamamak: yalnızlık & 26 & 33 \\
\hline $\begin{array}{l}\text { 2. Psikolojik meseleler: can sıkıntısı, rahatsız edici düşünceler, umutsuzluk, hüzün, } \\
\text { belirsizliğe dayanamama, endişe, kontrol arayışı }\end{array}$ & 21 & 27 \\
\hline 3. Online/uzaktan eğitim: teknoloji, bilgisayar, internet, telefon & 21 & 26 \\
\hline 4. Eve hapsolmak: dişarıya ve başka șehre gidememek & 19 & 24 \\
\hline 5. Sosyoekonomik sıkıntılar & 12 & 15 \\
\hline $\begin{array}{l}\text { 6. Aile ile yaşamaktan kaynaklanan meseleler: kalabalık aile; aile içi tartı̧̧malar; aile } \\
\text { içi eğlenceler; ailede iş yükü }\end{array}$ & 10 & 13 \\
\hline 7. Doğadan uzak beton binalar & 10 & 13 \\
\hline $\begin{array}{l}\text { 8. Maneviyat/spiritüalizm eksikliği: aşkınlık, din, sabır, huşu, şükür eksikliği ve } \\
\text { insanlara yardım edememek }\end{array}$ & 6 & 7 \\
\hline $\begin{array}{l}\text { 9. Psikolojik rahatsızlık/bozukluk: depresyon, anksiyete, bipolar, OKB, internet } \\
\text { (sanal/sosyal medya, oyun) bağımlılığı }\end{array}$ & 5 & 6 \\
\hline $\begin{array}{l}\text { 10. Kurum ve kuruluşların profesyonel olmaması: korkutucu medya, yasaklar, } \\
\text { kurallar, sömüren dünya devleri }\end{array}$ & 5 & 6 \\
\hline 11. Programsızlık ve yarım kalan işler & 5 & 6 \\
\hline 12. Kendindelik eksikliği: kendine zaman ayıramama & 3 & 4 \\
\hline 13. Köyde altyapı yetersizliği & 3 & 4 \\
\hline 14. Sağlık alanında çalışan aile üyeleri & 2 & 3 \\
\hline 15. Akademide empati eksikliği & 2 & 3 \\
\hline 16. İnsanların COVID-19 kurallarına uymaması & 2 & 3 \\
\hline 17. Sağlıksız beslenme & 2 & 3 \\
\hline 18. Eğitimsizlik & 2 & 3 \\
\hline 19. Spor yapamamak & 2 & 3 \\
\hline 20. Televizyon izlemek & 2 & 3 \\
\hline 21. Diğer: katılımcı tarafindan tema verilmeyen & 11 & 14 \\
\hline
\end{tabular}

\section{Kolaylaştırıcı ve Zorlaştırıcı Temaların EST'ye Atfedilmesi}

Katılımcılardan 14 kişi bu basamağı tamamen atlamıştır. Geriye kalan 113 kişi kolaylaştırıcı ve zorlaştırıcı faktörleri araştırma formunda verilen EST sistemlerine (bireysel/içsel, mikrosistem, ekzosistem ve makrosistem) Tablo 3 'te gösterildiği gibi atfetmiştir. Katılımcılar birden çok sisteme atıfta bulunabilmişlerdir.

Tablo 3: Kolaylaştırıcı ve Zorlaştırıcı Faktörlerin EST Sistemlerine Atfedilmesi

\begin{tabular}{lcccc}
\hline $\begin{array}{l}\text { Atfedilen sistem } \\
\text { ve faktörler }\end{array}$ & Bireysel/içsel & Mikrosistem & Ekzosistem & Makrosistem \\
\hline $\begin{array}{l}\text { Kolaylaştıııcı faktörler } \\
\text { Zorlaștırıcı faktörler }\end{array}$ & $\% 86(n=97)$ & $\% 10(n=11)$ & $\% 46(n=52)$ & $\% 35(n=40)$ \\
\hline
\end{tabular}

4. Veri Analizinin Gerçek ve Sanal Yollarla Paylaşılmasıyla Elde Edilen Bulgular

Analiz sonuçları COVID-19 bağlamı göz önüne alınarak yüz yüze sadece birkaç üniversite yetkilisiyle paylaşılmıştır. Sonuçlar daha çok sanal/sosyal medya ve e-posta kullanılarak ilgili kişi, kurum ve kuruluşlarla paylaşılarak ilgili olan kişilerin birbirleriyle etkili, kritik ve anlamlı diyaloglar oluşturması sağlanmıştır. Araştırmacı ve katılımcılardan gönüllü paydaşlar yaşanan meselelerin ele alınması ve genel iyilik hâlinin artırılması için bu kritik ve anlamlı diyaloglarla aktif sosyal savunuculuk yapmaya devam etmektedir.

\section{Tartışma}

COVID-19 süreci birçok insanı ve özellikle de üniversitede okuyan öğrencileri biyopsikososyal manevi ve ekonomik olarak etkilemiştir. $\mathrm{Bu}$ araştırmada elde edilen bulgular 
Türkiye'de COVID-19 sürecinde üniversite öğrencileriyle yapılan araştırmaların sonuçlarıyla benzerlik göstermektedir (Akyol vd., 2020; Gençalp, 2020; Gumusgul \& Aydoğan, 2020; Kürtüncü \& Kurt, 2020; Sarıtaş \& Barutçu, 2020; Tanhan vd., 2020). Araştırmanın sonuçları aynı zamanda COVID-19 sürecinde Çin (Cao vd., 2020) ve ABD (Alsandor \& Yilmazli Trout, 2020; Rose, 2020) gibi ülkelerdeki üniversiteli öğrencilerle yapılan araştırmalar ve konu üstüne yapılan sistematik alanyazın taraması araştırmalarıyla da (Viner vd., 2020) benzerlik göstermektedir. Bu yüzden Tanhan vd. (2020) COVID-19 bağlamında genel olarak tüm insanlar ve özellikle de üniversite öğrencilerinin meselelerini ele almak ve öğrencilerin yaşam kalitesini yükseltmek için OSF'yi kullanan araştırmalar için çağrıda bulunmuştur. Mevcut araştırmanın ilgili alanyazına kattığı özgün değer araştırmanın dört temel amacı çerçevesinde tartışılabilir.

\section{En Önemli Kolaylaştırıcı ve Zorlaştırıcı Faktörlerin Ele Alınması}

COVID-19 sürecinde üniversiteli öğrencilerin yaşamını kolaylaştıran ve zorlaştıran biyopsikososyal manevi ve ekonomik en önemli faktörler OSF kullanılarak katılımcıların kendi biricik perspektifinden keşfedilmiştir.

Kolaylaştırıcı ana temalar. Kolaylaştırıcı faktörler için 19 ana tema ortaya çıkmıştır. Katılımcilar tarafindan en fazla tekrar edilen ilk ana tema $(\% 33, n=42)$ an'da, kendinde veya mindful olma olmuştur. Katılımcılar bu tema için farklı kelimeler kullanmış olsa da genelde an'da, kendinde veya farkında olma, mindfulness veya kendini dinleme gibi kelimeleri kullanmıştır. Araştırmacı, Türkiye'de üniversite öğrencileriyle COVID-19 bağlamında yapılmış ve bu sonucu destekleyecek tek bir araştırmaya (Tanhan vd., 2020) denk gelmiş olmakla beraber, an'da olmanın COVID-19 sürecinde insanların hayatını kolaylaştırdığını destekleyen farklı araștırmalar mevcuttur (Arslan vd., 2020; Çiçek vd., 2020). Bu araştırmacılar aynı zamanda, insanların iyilik hâllerini artırmak için, an'da olmayı ruh sağlı̆̆ hizmetlerinde temel bir süreç olarak ele alan Kabul ve Kararlılık Terapisinden (KAT) de faydalanmayı önermişlerdir. Kant'ı psikolojik danışmanlık hizmetlerinde ve eğitimlerde uzun yıllardır kullanan ve konu üstüne bilimsel çalışmalar yapan mevcut makaledeki araştırmacı KAT'ın tek tek (K-A-T) harf şeklinde okunmasından ziyade tek bir kelime şeklinde okunduğunda daha anlamlı olduğunu önermektedir. Bu şekilde KAT'ın orijinal İngilizce isminde (Acceptance and Commitment Therapy: ACT) de olduğu gibi terapinin ismi tek tek harf (A-C-T) değil manalı bir çağrışım yapacak şekilde tek kelime (ACT yani değerlerin doğrultusunda harekete geçmek) şeklinde kullanılmasıyla da paralellik göstermiş olmaktadır. Benzer şekilde, araştırmacı burada KAT kelimesininim ruh sağlı̆g hizmetlerinde danışanla defalarca kullanıldığından ve KAT'ın teorik alt yapısında da kelimelerin nasıl kullanıldığının insan ruh sağlı̆̆ı üzerindeki etkisini de düşünerek tek kelime (KAT) olarak kullanılmasını, diğer bazı farklı kısaltmalardan, danışanlarla yaptığı bireysel ve bibliyoterapi çalışmalarında daha uygun bulmuştur (Tanhan vd., 2020). Burada tek kelime KAT ile danışanın kendi hayatına anlam, mana, değer, adanmış/kararlı davranış, kendindelik/an'da olma gibi süreçleri KATmak gibi pozitif bir çağrışım oluşturmak istenmektedir. Diğer bazı araştırmacılar da an'da olmanın genel olarak insanlar için (Tanhan, 2019) ve üniversiteli öğrencilerin ruh sağlı̆̆ için zor veya kolay fark etmeksiniz her durumda koruyucu bir faktör olduğunu bulmuştur (Tanhan \& Francisco, 2019; Tanhan \& Strack, 2020; Viskovich \& Pakenham, 2019).

Aşağıdaki paragraflarda ana temaları temsilen bazı katılımcıların fotoğraf, hikâye ve temaları verilmiştir. COVID-19 sürecinde yazıldıkları ve muhtemelen birçok katılımcı yazı yazmak için telefonlarını kullandığı için satır aralarında yazım hataları ve karışık zihinsel duygu ve düşünceler görülebilir. OSF'de anlam ve aktarılmak istenen mesaj önemli olduğu için ve pandemi sürecinin biyopsikososyal manevi ve ekonomik etkisinin satır aralarında okuyucular tarafindan hissedilmesini sağlamak için katılımcıların fotoğraf, hikâye ve temalarında sadece özel isim veya bilgi içerdiği zaman değiş̧iklik yapılmıştır. Bu değişiklik özellikle katılımcıları ve diğer insanları korumak için yapılmıştır. Yapılan değişiklikler hikâye içinde [....] şeklinde gösterilmiştir. Aşağıda yer alan ilk üç 
fotoğraf, hikâye ve tema kolaylaştırıcı ve diğer sonraki üçü ise zorlaştırıcı ana temaları temsilen seçilmiş̧ir. Temsili örneklerin araştırmada önerilen OSF adımlarına olabildiğince uyan ve ana temaları olabildiğince içerenlerden seçilmesine dikkat edilmiştir.

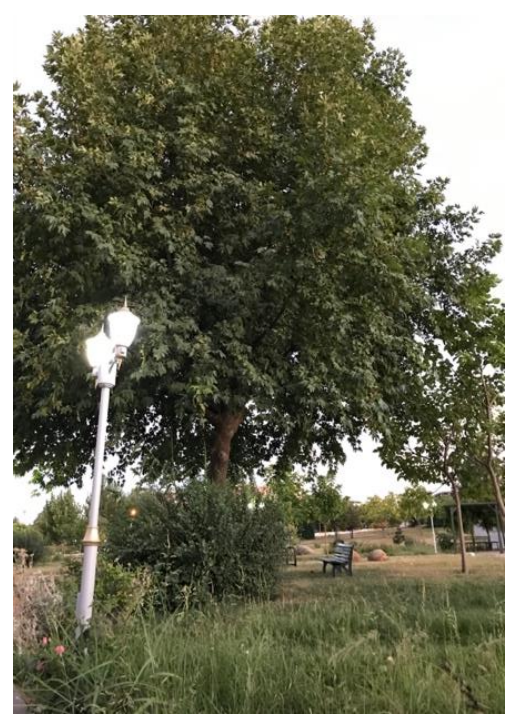

Fotoğraf 1: Bir numaralı katılımcının COVID-19 sürecinde hayatını kolaylaştıran en önemli faktörle ilgili fotoğraf karesi. Katılımcı fotoğrafı kolaylaştırıcı faktör için göndermiştir. Bu fotoğrafı gönderen katılımcı çalışmaya ilk katıldığında internetten bulduğu ve indirdiği başka bir fotoğrafla katılmıştır. Katılımcı araştırma sürecinde TeTKA perspektifinden çalışmada gönüllü çalışmaya başlamış yani paydaş olmuştur. Katılımcı bu süreçte OSF'de genellikle katılımcının kendisinin çektiğgi fotoğrafla katılmasının daha anlamlı olduğunu daha iyi anlamış ve fotoğrafını değiştirmek istediğini araştırmacıya ileterek kendisinin çektiği yukarıdaki fotoğrafla katılmıştır.

Katılımcının Gönderdiği Hikâye/Yorum: (Not: Hikâyelerdeki gramer hataları OSF perspektifinden hareketle olduğu gibi bırakılmıştır. Bunun amacı ilgili kişi, kurum ve kuruluşların hikâyeyi olabildiğince bağlamı içinde okumaları ve hissetmelerini kolaylaştırmaktır.)

Esenlikler ya da selamünalyküm [...] fotoğrafı baya aradım çünkü artık bu fotoğraf benim için çok önemli bir anlam taşıyor. Fotoğrafta beugüne kadar birçok şeyi kendimde değil de sanki diğer insanlar için ve belki de bilmiyorum onlar için de yapmadım. Yani bilmiyorum kimin için yaptı̆̆ımı. Evet elhamdülillah müslümanım ama inanın bu yani șuurunda olma, kendinde olma ya da mindfulle olmaya ihtiyacım var ve bunun bizim müslüman dğerlerle uyuştuğunu ilk derste [anlatan hocamız] çok güzel anlattı başka yerde duysaydım büyük ihtimal aforoz ederdim kelimeyi. Onun için fotoğrafta yeni kendimi görüyorum tabi [PDR Ana Bilim Dalı altında yürütülen] klinikte katıldığım otpler [OkumaTefekkür etme-Paylaşma] de apayrı bir değer kattı. Grup kolaylaştırıcımız [.....] da çok değer kattı bana. Fotoda bunları da görüyorum. Fotoda kendini dinleyen birini görüyorum diğer insanların da dinleyen birini yani bu süreçte en çok ihtiyacımız olan şeyi. Bu virüsten dolayı evlerimize kapanınca buna çok ihtyiacım oldu çünkü ailemle aram iyi değil hatta 2 hafta kalabildim onlarla ama 2 hafta boyunca kendimde oldum ve sanırım bu kadardı sonra kendime ve onlara biraz şefkat göstermek iin arkadaşların yanına gittim yoksa ben tükenecektim. Ailem de eskiden tartışmalarıma alış̧ı̆̆ için bu defa tartışmıyordum ve sadece dinliyordum ve sanırım bud aha da çıldırttı özellikle de babamı. Nyie konuşmuyorsun diyorlar, iyi misin diyorlar, deli mi oldu diyorlar, kitabı klinikten [PDR uygulama birimi] almıştım [... ] iyi ki almışım kitaba bakıp ne oldu diyorlardı... bir ay sonra ailemin yanına yine gittim amah ala aynı cehennem hal aynı yerdeler boş tartışmalar kendilerini küfürler argolar 
yemeler...madde kullanan kardeşim...sanırım hepsinin yardıma ihtiyacı var gerçekten. Bu konuda yönlendirmeniz için de sağolun [...] hocam. hafta sonra bunları yazarken huzurlu hissediyorum çünkü kendimde olduğumu ve bunun eskiden olsaydı bencilce olmadğğını biliyorum. Bu eve kapanma günlerinde en önemli kolaylaştırıcım namazlarımı kuraımı kendimde okumak oldu, arkadaşlarım günleri ve saatleri karıştırdı ben de biraz ama kendimde vakit namazlarının beni nasıl bilgilendridiğini anladım ilk defa hayatımda. Bu bozuk düzende birgün zindanlara düşersem sanırım günleri ve zamanı kaybetmemk için namazı kılacam kendimde. Bence sizzler ve yöneticiler insanlara [PDR] klininiğindeki etkinlikleri ulaştırmalyız ben eskiden çok aptalca görüyordum psikolojik danışmanlığı psikologları ama gerçetken önemli [....]. Ailem ve özellikle babam için online okumaya katılmasını istiyorum, üzülüyorum aileme. Bu çalışmada paydaş olarak katıldığım ve internetten hazır fotoğraf yerine biraz daha zaman ayırarak yukarıdaki fotoğrafla çalışmaya katılmamı sağlayan araştırmacı hocama teşekkür ediyorum.

Katılımcının Gönderdiği Tema: “Alışkanlıklarımı kendimde yapmak, ibadet, arkadaşlar”

İkinci ana tema aile, akraba, arkadaş ve yakın çevre ilişkileri $(\% 18, n=23)$ olmuştur. Katılımcıların çoğu COVID-19 sürecinde aile, akraba, arkadaş ve benzeri gibi yakın çevrede bulunanlarla bir ilişki ve iletişimlerinin olmasını çok önemli bir destek olarak ifade etmişlerdir. Mevcut araştırma gibi bu temayı bir destek olarak COVID-19 sürecinde ele alan başka araştırmaya rastlanılmamakla beraber aile, arkadaş ve akraba gibi ilişikleri COVID-19 sürecinde önemli bulan başka araştırmalar da olmuştur (Çetin \& Anuk, 2020; Genç vd., 2020; Gençalp, 2020; Kürtüncü \& Kurt, 2020). Farklı ülkelerde de ailenin pandemi sürecinde önemli bir destek olduğu görülmüsstür (Cao vd., 2020; Otanga vd., 2020). Ruh sağlığı hizmetlerinde de birey, çift, grup veya topluluklara hizmet verirken ampirik olarak oldukça güçlü terapilerde de mikrosistem ve mezosistem düzeyindeki aile gibi faktörlere dikkat edilmesi gerektiği vurgulanmıştır (Tanhan, 2019).

En az bu tema kadar vurgulanan bir sonraki üçüncü, ana tema maneviyat/spiritüalizm olmuştur: $(\% 18, n=23)$. Bu ana temada katılımcıların büyük çoğunluğu Müslüman olmanın getirdiği bazı tutum, düşünce, perspektif ve davranışlardan (örn., namaz, şükür, ibadet, inanç, sabır, oruç, hayır işlemek, İslam'ın bakış açısı) dini kurallardan öte bunların işlevselliğinden bahsederek kendilerine zorlu COVID-19 sürecinde destek olduğundan bahsetmiştir. Bunun yanı sıra bazı katılımcılar Müslüman olmanın veya İslam'ın getirdiği destekten bahsederken bazıları bundan hiç bahsetmeyerek maneviyatı kendisinin ötesinde ve kendisini aşan bir aşkınlık (örn., insanlık, keşfedilmesi gereken bir mesaj) şeklinde ele almıştır. Türkiye'de COVID-19 bağlamında spesifik olarak üniversitelilerden ve spiritüalizmden bahseden araştırma çok az olmakla beraber (Tanhan vd., 2020), yapılan araştırmalar genel olarak bu pandemi sürecinde spiritüalizmin insanlar için önemli olduğunu vurgulamıştır (Arslan vd., 2020; Çiçek vd., 2020; Kirman, 2020). COVID-19 sürecinde üniversitelilerle (Otanga vd., 2020; Tanhan vd., 2020) veya genel olarak diğer insanlarla maneviyatın birkaç araştırma (Borasit vd., 2020; González-Sanguino vd., 2020; Tanhan vd., 2020) dışında çalışılmadığ 1 görülmektedir. Bundan dolayı mevcut araştırma önemli bir boşluğu kapatmaktadır. Spiritüalizmin üniversiteli ve genel olarak insanlar için en önemli desteklerden birisi olduğu araştırmalarla desteklenmiştir (Otanga vd., 2020; Tanhan \& Francisco, 2019; Tanhan \& Francisco, 2019).

Bir sonraki ve katılımcıların \%21'inin $(n=17)$ bahsettiği ana tema doğa olmuştur. Katılımcıların büyük çoğunluğu bahçe, bitki, toprak, hayvan, gökyüzü gibi doğanın parçalarından ve bazıları da özellikle köy veya kırsal yerlerde zaman geçirerek beton ve dört duvar arasında kalmadıklarından bahsederek tüm bunların pandemi sürecinde kendilerine çok iyi geldiğini ifade etmiştir. Birçok katılımcı karantina günlerinde sınırlı da olsa bahçelerindeki bitki, ağaç, toprak veya evlerinde ilgilendikleri bitkilerden bahsetmiştir. Türkiye'de ve dünyada doğanın bu pandemi sürecinde insanları nasıl etkilediği üstüne başka bir araştırmaya rastlanmamıştır. 


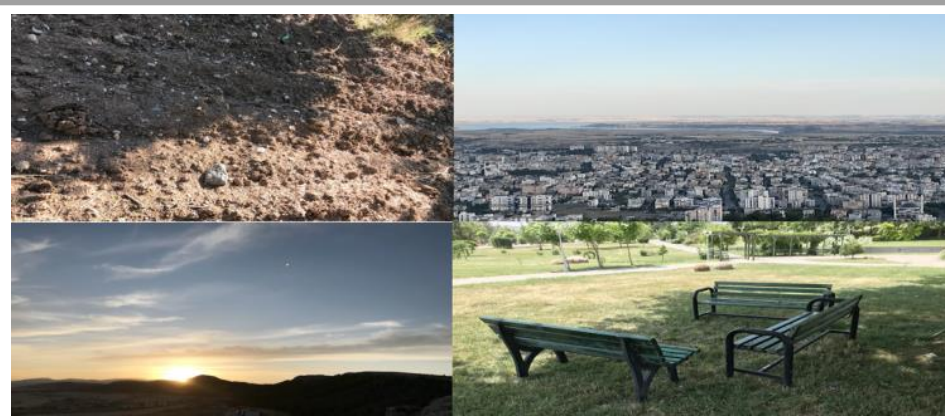

Fotoğraf 2: Katılımc1 49'un COVID-19 sürecinde hayatını kolaylaştıran en önemli faktörle ilgili fotoğraf karesi

\begin{abstract}
İlk fotoğraf bizim tarladan, son fotoğrafi arkadaşımdan aldım ve o da katıldı çalışmaya. Toprakla uğraşmak çiftçilik yapmak çok güzel bir şey. Kendi tarlamızda büyüyen sebze ve meyveyi yemek kadar güzel brik şey yok. Karantina sürecinde çoğu zaman babamla ve ailemle tarlaya gittik. Çok güzel beraber iş yaptık. herkese öneriyorum. Bence yöneticiler öğrencilere haftalık 3-4 saat tarlada çalışma dersini zorunlu hale getirmesi lazım. Stresimi yok etti. Ayrıca klinikte yapılan OTP ye de katıldım, diğer kitaplardan ve derslerimden okumalarımı tarlada da doğa içinde yaptım, mindful çalıştım okudum. Sanat ve özellikle de fotoğrafla çok ilgileniyorum. Bu dört foto ile şunu anlatmak istedim kitap okuyalım topraktan daha güzel şehirler doğsun, beton evler değil. bence herkesin ot ye de katılması lazım. OTP etkinliğinde aynı zamanda sağlıklı beslenmeyi ele alan bir kitap için de ele alın yani sağlıklı beslenme üzerine ot iyi olabilir beraber okuyunca güzel oluyor dönem bitsin otpler bitmesin ve $[\ldots .$.$] otpleri bu defa lütefen dışarda paylaştı̆ıım masalarda yapalım. hükümetlerin tarımı$ ve beslenmeyi desteklemesi lazım.
\end{abstract}

Tema: "sağlıklı beslenme, kitap, otp, resim-foto, evrene bir şeyler bırakma"

Beşinci stradaki ana tema sanat $(\% 17, n=13)$ olup bazı katılımcılar film izlemekten ve videolarla diğer büyük bir kısmı en çok resim yapmak ve müzikle ilgilenmekten bahsetmiştir. Müzik ve resim bölümlerinde okuyan bazı öğrenciler de online veya uzaktan eğitimi yüz yüze eğitimden zaman, ekonomik ve virüsten korunma gibi nedenlerden dolayı daha avantajlı bulduklarını ifade etmişlerdir. Bununla beraber müzik ve resim gibi alanlarda okuyan bu öğrenciler online veya uzaktan eğitimde bire bir eğitimin ve pratik yapmanın eksikliğinden ve ekonomik durumu düşük olanlar için pandemi sürecinde online eğitimin zorluğundan da bahsetmişlerdir. Avci (2020b) çalışmasında bağlamsal şartlara göre eğitimde ve özellikle müzik alanındaki online eğitimde dijitalleşmeye dikkat çekmiştir. Ayrıca diğer birçok katılımcı da uzun zamandır ilgilenmedikleri bu alanlara bu zorlu süreçte zaman ayırdıklarını ve bunu çok etkili bulduklarını ifade etmiştir. Sanatın pandemi sürecinde üniversiteli öğrenciler için etkili olduğu diğer araştırmalarda da görülmüştür (Akyol vd., 2020; Otanga vd., 2020). Ruh sağlığı hizmetlerinde sanatın önemli bir yeri hatta sanatla terapi gibi tek başına yaklaşımlar olsa da literatür taramasında COVID-19 bağlamında sanatın insan psikolojisine etkisinden bahseden çok fazla araştırma bulunmamıştır.

En az üç katılımcı tarafından ifade edilen temalar diğer ana temalarla biraz benzerlik göster se de OSF'de katılımcıların fotoğraf, hikâye ve temalarını olabildiğince olduğu gibi aktarmak için ayrı bir ana tema altında tutulmuştur. Ana temaların birçoğu birbiriyle ilişkili olmakla beraber bazıları birbiriyle daha fazla ilişkili olmuştur. Bu ve bir sonraki paragrafta yer alan altıncı, yedinci ve sekizinci ana temalar ayrı olsa da aslında birbirleriyle diğer ana temalara göre daha ilişkilidir. Altıncı ana tema kitap okuma $(\% 12, n=15)$ olmuştur. Katılımcılar zorlu pandemi günlerinde eğlenmek, bilgi edinmek ve hobi için kitap okuyarak zaman geçirdiklerini ve bunu faydalı bulduklarını ifade etmişlerdir. Bu ana temadaki kitaplar üçüncü temada yer alan manevi/spiritüalist kitap okumalardan, dokuzuncu ana temadaki online/uzaktan ders ve 14. ana temadaki ruh sağlığ hizmetleri altında yer alan bibliyoterapi hizmetlerinden farklı tutulmuştur. Bunun temel amaci bu altıncı temada katılımcılar her türlü kitaptan bahsetmiş ve belli bir sistem veya perspektiften ziyade 
sadece kitap okumanın faydalı olduğundan bahsetmiştir. COVID-19 alanyazında eğlenceyi, genel olarak bilgi edinmeyi ve hobi şeklinde kitap okumayı ele alan başka araştırmalar ile mevcut araştırmanın sonuçları benzeşmektedir (Akyol vd., 2020; Otanga vd., 2020). Pandemi sürecinde profesyonelce seçilmiş kitap okumalarının üniversiteliler ve yetişkinler (Tanhan vd., 2020) ve çocuklar (Çaykuş \& Çaykuş, 2020) üstüne etkisini ele alan araştırmaların da sınırlı olduğu görülmüştür. Bu açıdan mevcut araştırmada ders veya ruh sağlığı gibi profesyonel bir perspektifin dışında, genel bilgi edinmek, eğlenmek ve bir hobi olarak kitap okumanın da önemli bir destek olacağ1 görülmüştür.

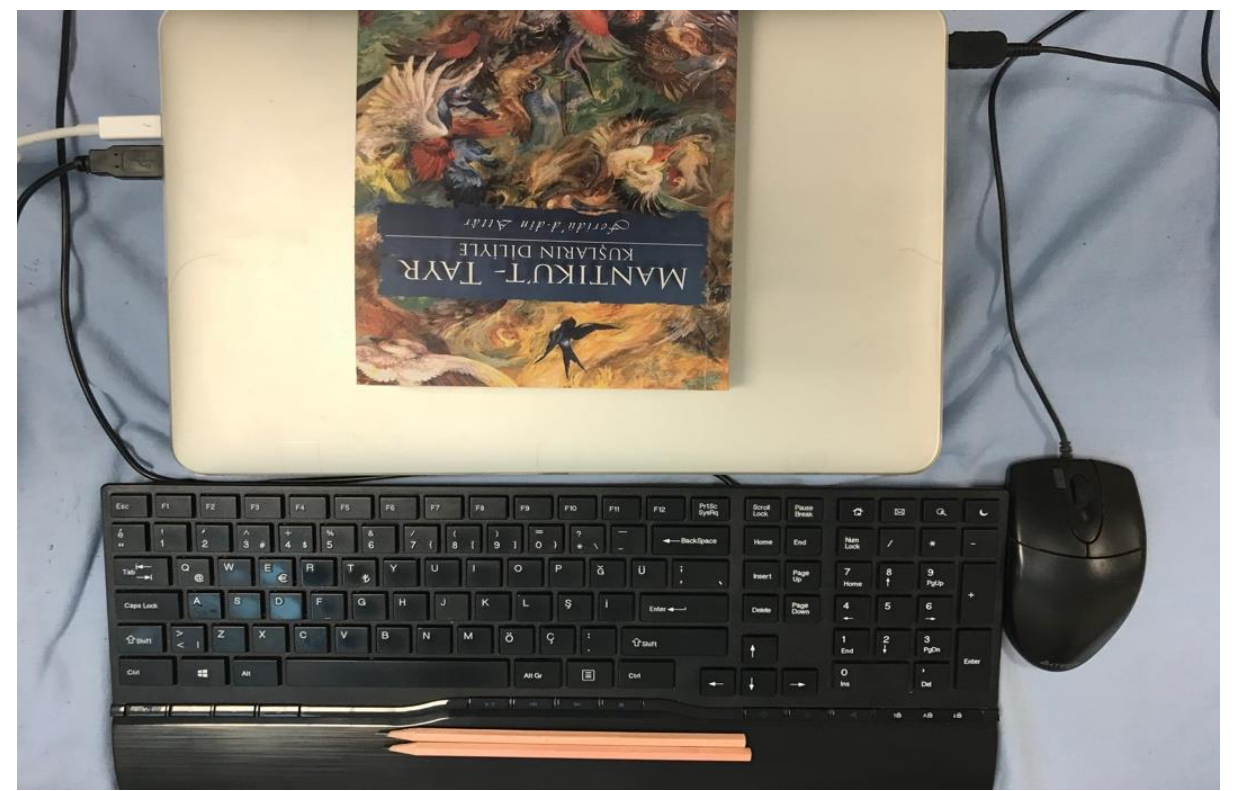

Fotoğraf 3: Katılımc1 77'nin COVID-19 sürecinde hayatını kolaylaştıran en önemli faktörle ilgili fotoğraf karesi. Bu fotoğrafi gönderen katılımcı çalışmaya ilk katıldığında internetten bulduğu ve indirdiği başka bir fotoğrafla katılmıştır. Katılımcı araştırma sürecinde TeTKA perspektifinden çalışmada gönüllü çalışmaya başlamış yani paydaş olmuştur. Katılımcı COVID-19 sokağa çıkma sürecinde evde kamerası iyi olan bir cihaza sahip olmadığını ve internetten bulduğu bir fotoğrafla katıldığını ifade etmiştir. Bu çalışmanın makalesinin yazılması sürecinde araştırmacıyı ziyaret ederek kamerası iyi olan bir cihaz ödünç almış ve kendi hikâyesine ses katan yukarıdaki fotoğrafı çekmiş ve bu fotoğrafin kullanılmasını istemiştir.

Güzel sanatlar fakültesinde öğrenci olduğum için sanata, filmlere, müziğe hep ilgim olmuştur. Bu evde kaldığımız günlerde ilk defa online konserlere katıldım arakdaşlarıma müzik dinletisi verdim. Daha önceden böyle bir şey düşünmezdim bile. Ilk başlarda biraz canım sıkıldı ve hep film müzik diye gitti ama sonra yavaş yavaş derslerimize de başladık online olarak. Internetin ve teknolojinin faydasını gördüm. Tabi benim ailemin maddi gücü vardı en iyi bilgisayarı almak ancak bu herkes için böyle değil. Ve internet her zamanda iyi bir şey değil çünkü ilk günlerde zombie gibi hissetim beş saniyede bir sosyal medya hesapblarımı kontrol etmem sinirlenmem ama hepsi geçti şükür şimdi teknolojinin artılarını kullanıp yeni şeyler öğrenemye çalışıyorum. Birçok diğer avantjı da var gerçekten. Bence yavaş yavaş üniversiteler ve diğer kurumlar ve aslında devlet bazı dersleri, işleri tamamen online olsun. Hatta bu dönemde hiç grip, nezle olmadım çok az başım ağrıdı yani bunlar da covidin artıları ama tabi ki sosyal haayt apayrı. Yukarıdaki fotoğrafım internetten indirip kullandığım fotoğrafla çok benziyor sadece bu çok daha beni yansıtıyor. Kitap da herkesin ancak özellikle de Güzel Sanatlar Fakültesinde okuyan kişilerin çok faydalanacağı bir kitap. Bu kitapla bu araştırma sürecinde ve tanışım ve bu pandemi sürecinde bana gerçekten çok faydalı oldu. Güzel sanat hem içe hem de dışa nakşediyorsa daha anlamlıdır. Bu araştırmaya katıldığım ve tüm hikayeleri okuduğum ve ilgili kişilere ve kurumlara da ulaşacağım iin mutlu hissediyorum. Keşke böyle şeylere daha çok katılsak tüm öğrenciler olarak. 
Tema: "online ders, öğrenmek, müzik, teknolojinin artıları"

Yedinci ana temada kat1lımcilar $(\% 12, n=15)$ zorlu pandemi sürecini bir firsat bilip bunun arkasındaki anlam/mana arayışından bahsetmiştir. Bu konuda Türkiye ve dünyada birçok araştırmacı konuşmalarında bu zorlu pandemi sürecinde insanların bir anlam/mana arayışı içine girdiğini söylemiş olsa da bu konuda yapılan ampirik araştırmalar (Karataş, 2020; Tanhan vd., 2020) çok sınırlı kalmıştır. Bu açıdan ortaya çıkan bu ana tema literatüre önemli bir değer katmıştır. Sekizinci ana tema ise $(\% 11, n=14)$ kendini geliştirme yani yeni bir şeyler öğrenme olmuştur. Katılımcılar uzun zamandır düşündükleri veya hiç düşünmedikleri yeni beceri, alışkanlık, tutum ve düşünceler geliştirmekten bahsederek bunun kendileri için çok önemli bir destek olduğunu ifade etmiştir. $\mathrm{Bu}$ sonucu destekleyen diğer bazı COVID-19 araştırmaları olduğu görülmüş̧ür (Akyol vd., 2020; Tanhan vd., 2020); bazı araştırmacılar da bu süreçte yeni rekreatif (örn., hızlı eller, tik-tak-tok ve denge) oyunların öğrenilmesini önermiştir (Gümüşgül \& Aydoğan, 2020).

Dokuzuncu kolaylaştırıcı ana tema $(\% 10, n=13)$ online/uzaktan eğitim ve bunu sağlayan alt faktörler (e-learning, teknoloji, bilgisayar, internet vb.) olmuştur. Katılımc1lar online veya uzaktan eğitimi fiziki/sınıfta eğitime göre daha etkili bulmuş, bazıları tamamen veya kısmen online eğitime geçmeyi önermiş ve eğitimin online sürmesinin pandemi sürecinde hayatlarını kolaylaştırdığını ifade etmişlerdir. Online eğitimi Türkiye'de pandemi sürecinde bir kolaylaştırıcı olarak bulan başka bir araştırmaya denk gelinmediğinden mevcut bulgu alanyazına özgün bir değer katmaktadır. Bir sonraki, 10. kolaylaştırıcı ana tema ise diğer insanlara yardım etme yani tebessüm etme, empati kurma ve faydalı bir şeyler üretmek gibi tutum ve davranışları içermiştir $(\% 9, n=12)$. İlgili COVID19 alanyazında insanların diğer insanlara yardım etmesi üstüne ampirik araştırma olmamasına rağmen Tanhan vd. (2020) birçok meslekten insanın ve aktif üniversite öğrencilerinin online olarak gönüllü çalışarak COVID-19 sürecini insanlar için kolaylaştırmaya çalıştığını ve aynı zamanda bunu kendileri için de anlamlı bulduklarını ifade etmişlerdir. İnsanlara ve evrene faydalı olma insan doğasıyla da ilgilidir.

Yukarıda sayılan ana temaların dışında kalan temaları ifade eden katılımcı oranı \%10'un altında kaldığ 1 ve araştırmada yer sıkıntısı olduğu için bu temalar göreceli olarak daha kısa bir şekilde ifade edilmiştir. Sosyoekonomik durumun iyi bir düzeyde olması 11. ana tema olarak bazı katılımcılar $(\% 6, n=7)$ tarafindan en önemli destek olarak ifade edilmiştir. 12. ana temada Türkiye'deki Milli Eğitim Bakanlığı (MEB), Sağlık Bakanlığı, YÖK gibi kuruluşların düzenli olarak bilgi sağlaması ve süreci insanlar için sağlıklı bir şekilde yürütme çalışmasını bazı katılımcılar (\%5, $n=6$ ) kolaylaştırıcı olarak ifade etmişlerdir. Diğer bazı araştırmacılar da benzer sonuçlar bulmuştur (Güreşçi, 2020; Karataş, 2020; Kırmızıgül, 2020; Tanhan vd., 2020). Bu iki ana tema araştırmanın teorik çerçevesini oluşturan EST’nin makrosistem (örn., hükümetlerin politikaları, toplum değerleri, ekonomi) düzeyine denk gelmektedir ve bu açıdan da bu iki ana tema düşük oranda da olsa alanyazına özgün bir değere katmaktadır.

COVID-19 karantina sürecinde bir plan/program yapıp bunu takip etmek bir sonraki, 13. ana temayl, oluşturmuştur $(\% 4, n=5)$. Çok az kişi bu ana temadan bahsetmiş olsa da araştırmanın yürütücüsü ruh sağlığı alanındaki klinik deneyimi ve kuramsal bilgisi dâhilinde genel ve özellikle de hoşa gitmeyen zamanlarda esnek bir program dâhilinde uyku, yemek, çalışma, sosyalleşme, spor veya manevi etkinliklerin devam etmesinin çok etkili olduğunu görmüştür. Araştırmacı aynı zamanda pandemi sürecinde hizmet verdiği danışanlara da esnek koşullar dâhilinde kendinde bir programın takip edilmesinin genel iyilik hâlinin sürdürülmesinde çok önemli olduğunu açıklamıştır. Dünyanın en önemli ruh sağlığ dernekleri, örneğin Amerikan Psikolojik Danışma, Psikiyatri ve Psikologlar Dernekleri de geçmişten günümüze zor ve olağan durumlarda esnek programların oldukça önemli olduğunu vurgulamıştır. Bu açıdan bu ana temanın ortaya çıkmış olması da alanyazına önemli bir değer katmaktadır. 
Bu paragrafta ele alınan üç ana tema ruh ve beden sağlığ ile ilgilidir. Katılımcıların aktarmak istediğini olabildiğince korumak adına ayrı ayrı ana temalar altında ele alınmıştır. On dördüncü ana tema profesyonel ruh sağlığ 1 hizmetleri $(\% 4, n=5)$ olmuştur. Katılımcılar üniversitelerindeki Psikolojik Danışmanlık ve Rehberlik (PDR) Ana Bilim Dalı (ABD) altında üniversitenin Psikiyatri $\mathrm{ABD}$ ile iş birliği içinde yürütülen ve COVID-19 sürecinde de online sürdürülen bireyle psikolojik danışmanlık, Okuma-Tefekkür etme-Paylaşma (OTP) grup bibliyoterapi gibi ruh sağlığı hizmetlerini önemli bir destek kaynağı olarak ifade etmiştir. Bu sonuçlar diğer bazı araştırmacıların sonuçlarıyla benzerlik göstermektedir (Bulut, 2010; Tanhan vd., 2020). On beşinci ana tema sağlıklı beslenme ve hoşa giden sağlıklı yemekler yapmak olmuştur $(\% 4, n=5)$. Bu sonuç diğer bazı araştırmacılar tarafından da üniversiteliler için önemli bir faktör olarak görülmüştür (Gençalp, 2020; Tanhan \& Francisco, 2020; Tanhan \& Strack, 2020). Mevcut araştırmada katılımcilar genelde aileleriyle olduklarını ve sağlıklı yemek yapma ve yemenin kendileri için en önemli kolaylaştırıcı faktörlerden biri olduğunu ifade etmişlerdir. Bu iki ana temaya benzer şekilde sağlıklı bir hayatın önemli bir bileşeni olan egzersiz/spor yapma 16. ana tema olmuştur $(\% 3, n=4)$ ve bu sonuç üniversitelilerle yapılan diğer bazı araştırmalarla benzerlik göstermektedir (Akyol vd., 2020; Gençali, 2020; Tanhan $\&$ Strack, 2020).

On yedinci kolaylaştırıcı ana tema akademide hocaların empatik davranması olmuştur $(\% 2$, $n=3$ ). Bir sonraki, 18. kolaylaştırıcı ana tema, pandemi sürecinde aile ile değil tek başına ya da arkadaşlarla yaşamak olmuştur $(\% 2, n=3)$. Üç katılımcı aileleri ile aile içi sıkıntılardan dolayı bu zorlu COVID-19 sürecinde tek başlarına yaşamayı seçtiklerini ve bunun kendileri için en önemli kolaylaştırıcı olduğunu ifade etmişlerdir. Çok az sayıda olmasına rağmen bu ana tema alanyazına önemli bir değer katarak ergenlerin anlaşılmasında ilgili ve yetkili kişilere yeni bir perspektif verebilir. Son olarak, 14 katılımc1 (\%11) tema belirtmediği ve OSF'de katılımcıların perspektifini olabildiğince olduğu gibi aktarma en önemli noktalardan biri olduğu için bu katılımcıların fotoğraf ve hikâyeleri 19. "Diğer" ana tema altında toplanmıştır. Bu katılımcıların büyük bir çoğunluğu aynı zamanda fotoğraf da göndermemiş sadece hikâyelerini paylaşmışlardır.

Özetle, bu araştırmada COVID-19 bağlamında ve Türkiye'nin doğu bölgesinde bulunan bir devlet üniversitesinde öğrencilerin yaşamındaki kolaylaştırıcı faktörler 19 ana tema altında toplanmıştır. Alanyazın tarafından kısmen desteklenen bu ana temalar alanyazına yeni ve özgün bir değer katmıştır.

Zorlaştırıcı ana temalar. Analiz sonuçlarına göre 21 zorlaştırıcı ana tema ortaya çıkmıştır. İlk ana tema 33 katılımcı (\%26) tarafından ifade edilen aile, akraba, arkadaş ve diğer sevilenlerle fiziki olarak beraber olamamaktır. Katılımcıların birçoğu birileriyle yaşamaktan bahsederken bile diğer sevilen kişilerle olamamaktan, yalnız hissetmekten de bahsetmiştir. Aile, akraba ve arkadaşlarla zaman geçirmenin özellikle de üniversiteli öğrenciler için önemli olduğunu diğer araştırmacılar da vurgulamıştır (Çetin \& Anuk, 2020; Gençalp, 2020; Tanhan \& Francisco, 2019; Tanhan \& Strack, 2020). Diğer bazı araştırmacılar da pandemi sürecinde özellikle sosyal izolasyona ve bunun yol açacağı diğer biyopsikososyal manevi ve ekonomik meselelere dikkat edilmesi gerektiğini vurgulamıştır (Çiçek vd., 2020; Genç vd., 2020; Tanhan vd., 2020).

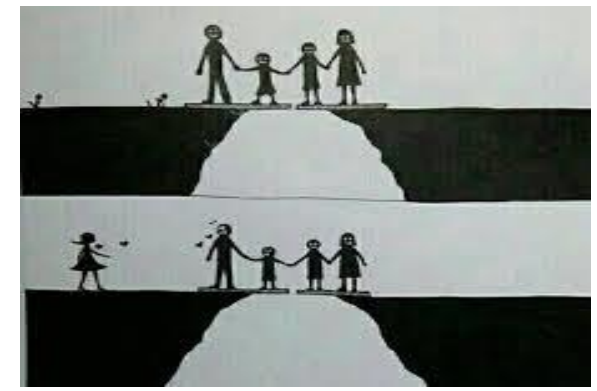

www.turkishstudies.net/turkishstudies 
Fotoğraf 4: Katılımc1 114'ün COVID-19 sürecinde hayatını zorlaştıran en önemli faktörle ilgili fotoğraf karesi

Fotoda beni ayrı olarak görüyorsunuz ama aslında daha emniyetteyim. Eskiden olsaydı bende onlarla olurdum yani sanki beabermiş gibi ama aslında beraber değiller. Hep çatışma var hep dünyalık ama ellerinde de bir şey yok. Doğrdu düzgün besleniyoruz dersem o da yalan olur ama ondan daha ktöüsü birbirine bakmayan kaç yıldır beraber yatmayan birbirine güzel birkaç kelime söyleyemen annem ve babam ve onların yanında kardeşlerim var. bunları yzarken ve dşünürken acı hissediyorum kalbimde ve tüm bedenimde. Onun için bu pandemi günlerdein onlarla çok az kaldım kalabilidm yoksa ben de tükenecektim. Bence bunun oluşmasnıa neden olan herkes yani anne babalarım öğretmenler özellikle devletten maaş alan ve hiçbir iş yapmayan anca yatıp maaş alan özellikle de hükümetler. Babam ve annem iiy insanlar ama işleri eğitimleri düşük imanları zayıf babam hep çok utandığım argo kelimlere kullanıyor aile iinde sanki br şey yok gibi kardeşlerim de başlamış ben de eskiden kullanıyordum ama ünviersdete biraz kendime çekidüzen verdim ama zor gerçekten çok zor kaç defa depreyona gididm ilaç kullandım bilen bilir ancak onun için bu virus günlerinde en zorlaştıcı şey namazsız ibadetsiz eğitimsiz bir ailemin olması bunun için ne yapabilirzi bence hepimiz çlaışmalı, ünvi. Siz biz ve yöneticiler ve hükümet gerçekten çalışmalı artık hayatın çok kısa olduğuna inanıyorum hocam onun için bir şeyler yapmak istiyorum ve yardımcı olabiilirim yani çalışmak isterim [OSF araştırmasında]. Gerçekten allaj razı olsun $[\ldots]$

Tema: "Çatışan eğitimsiz bilinçsiz maneviyatsız namazsız ibadetsiz aile"

Íkinci zorlayıcı ana tema psikolojik meseleler $(\% 21, n=27)$ olarak ortaya çıkmıştır. Katılımcılar, günlük hayattaki işlevlerini bozmayacak yani psikopatolojik düzeyde olmasa da, can sıkıntısı, stres, rahatsız edici düşünceler, umutsuzluk, hüzün, belirsizliğe dayanamama, gelecek hakkında endişe etme ve pandemi sürecini kontrol etmeye araştırma gibi psikolojik olarak hoşa gitmeyen his, duygu, düşünce ve davranışlardan bahsetmişlerdir. Başka araştırmacılar da benzer sonuçlar bulmuştur (Arslan vd., 2020; Çiçek vd., 2020; Haktanir vd., 2020; Yakar vd., 2020). İkinci tema ile oldukça ilişkili olan dokuzuncu ana temada altı (\%5) katılımcı depresyon, anksiyete, bipolar bozukluk, obsesif kompülsif (takıntılı zorlant11) bozukluk ve internet yani oyun ve sanal/sosyal medya bağımlılı̆g 1 gibi davranış bozukluklarından bahsetmiştir. Tanhan ve diğerleri (2020) de pandemi sürecinin ve özellikle de sosyal izolasyonun getirebileceği psikolojik meseleler ve bunların zamanla psikopatolojiye dönüşebileceğine değinmiş ve bunun için de kuramsal ve bağlamsal olarak iyi oturtulmuş disiplinler arası online ruh sağlığı hizmetlerini önermiştir.

Üçüncü ana tema 26 katılımcı (\%21) tarafindan ifade edilen online/uzaktan eğitimin zorlukları olmuştur. Katılımcılar ders için teknoloji, bilgisayar, internet ve telefon gibi elektronik cihazları kullanmaya çalıştıklarını ancak temel sıkıntılarla karşılaştıklarını ifade ederek uzaktan eğitimin önemli bir zorlayıcı olduğundan bahsetmiştir. Bazı katılımcılar uzaktan eğitim için gereken kaynaklara ya çok sınırlı düzeyde sahip olduklarını veya hiç sahip olmadıklarını ifade etmiştir. Diğer bazı araştırmacılar da online/uzaktan ders, hizmet veya araştırmaların birçok lisans öğrencisi için bağlamsal ve sosyoekonomik faktörlerden dolayı dersi tam takip edememe ve anlayamama ve kaynakların yetersizliğinden ödev ve sınavları yerine getirememe gibi bazı temel problemlere neden olduğunu bulmuştur (Liu vd., 2020; Tanhan vd., 2020; Yao vd., 2020). Bu da online veya uzaktan eğitimde teknolojinin iyice düşünülerek kullanılması gerektiğini göstermektedir (Bao vd., 2020; Çiçek vd., 2020; Kalkan, 2020; Tanhan vd., 2020; Wang vd., 2020).

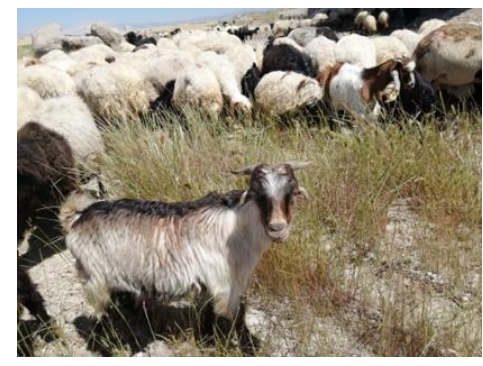

Turkish Studies, 15(4) 
Fotoğraf 5: Katılımcı 39'un COVID-19 sürecinde hayatını zorlaştıran en önemli faktörle ilgili fotoğraf karesi

\begin{abstract}
Köyde yaşıyorum ve birçok şey gerçekten çok çok eksik bunların hepsiinin tamamlanması lazım. Birinicisi [....] yani kent merkezinde bnalan bizler gibi herkes köye göçtü. köydeki nüfus bir kere çok arttı. Herkes köye geldi ama evler yetersiz ve birçok diğer şey de eksik mesela alt yapı, yollar, internet, evlere su, sıcak su. bunların düzeltilmesi lazım ki köylerimize geri deönebileleim sağlıkla afiyetle. köyde o kadar kişi olduki inanın şehirden daha fazla yoğun oldu ne kednirme ne derslerime zaman akladı. Köyde birçok insanın parası da olmadığı için bir şey yapamıyor yani parası var ama paraya tapmadığı için yok yoksa yaşayacak ve paylaşacak kadar hayvanımız, fistı̆̆ımız, bitkimiz ürünümüz var ama bunlarla altyapı yapılamaz sanırım. Devletin yapması lazım tüm bu işleri ve hiçbir şeye elini dokundurmayan yöneticilerin ve tabi ki konuşmaktan korkan bizlerin fotodaki birkaç aylık olan keçimiz bile buna katılıyor baksanıza yazık yani bu hayvanlara da onları yaşadığı köyde atık suların çoğu dışarıya akıyor yollar iyi olmadığı iin covidden önce çok az köye gidip onlarla ilgileniyordum yol iyi olsaydı çok daha fazla gider hatta ünviversteden arkadaşlarım da gelirdi.
\end{abstract}

Tema: "köydeki eksiklikler: yol, altypaı, internet, beton kent evleri, sıcak su, birden çok fazla kişi köye gelme"

Katılımcıların \%19'u $(n=24)$ pandemi sürecinde eve hapsolma, dışarıya çıkamama ve başka şehre yolculuk edememenin sıkıntılı ve hoş olmayan bir tecrübe olduğunu ve özgürlüklerinin ellerinden alınmış gibi hissettiklerinden bahsederek dördüncü zorlayıcı ana temayı oluşturmuştur. Diğer araştırmacılar da COVID-19 sürecinde karantina ve sokağa çıkma yasağ 1 sürecinde birçok kişinin bu durumu sıkıcı bulduğunu rapor etmişlerdir (Arslan vd., 2020; Çiçek vd., 2020). Beşinci ana temayı $(\% 12, n=15)$ sosyoekonomik sıkıntılar oluşturmuştur. Öğrenciler kendilerinin veya tanıdıklarının ekonomik sıkıntılar yaşamasını pandemi sürecini zorlaştıran en önemli faktör olduğunu ifade etmişlerdir. Bu sonuçlar diğer bazı COVID-19 araştırmalarıyla da benzerlik göstermektedir (Kürtünü \& Kurt, 2020; Tanhan vd., 2020).

Altıncı zorlaştırıcı ana temayı ise aile ile yaşamaktan kaynaklanan sorunlar oluşturmuştur. Katılımcıların \%10'u ( $n=13$ ) bu temada kalabalık aile; aile içi tartışmalar, eğlenceler, ziyaretler ve bunların hepsinden dolayı ortaya çıkan iş yükü gibi meselelerin en az birinden bahsederek bunların süreci zorlaştırdığını ifade etmiştir. Genç vd. (2020) COVID-19 gibi afet ve kriz dönemlerinde yaşanan stresin aile ilişkilerine yansıdığına ve bu durumun aile içinde yaşanan çatışmaların artmasına ve bireylerdeki ruhsal problemlerin tetiklenmesine neden olabileceğine değinmiștir. Tanhan ve diğerleri de (2020) benzer bir durumdan bahsetmiş ve zorlu pandemi sürecinde ailesiyle yaşayan öğrencilerin bağlamsal şartlarının düşünülmesini önermiştir. Doğadan uzak beton evlerin içinde yaşamanın COVID-19 sürecini oldukça zorlaştırdığını ise 13 katılımcı (\%10) ifade ederek yedinci zorlaş̧ıııcı ana temayı meydana getirmiştir. Katılımcılar toprak, hayvan ve bitki gibi doğanın diğer bileşenlerini içeren ev ve şehirlerde yaşamak istediklerini ifade etmiştir. Benzer sonuçlar diğer bazı COVID-19 araştırmaları tarafindan desteklenmektedir (Özkaral \& Bozyiğit, 2020). Ercengiz vd. (2014) de Türkiye'nin doğusunda yaptıkları bir araştırmada üniversiteli öğrencilerin çevre duyarlılığının orta düzeyde olduğunu bulmuştur. 


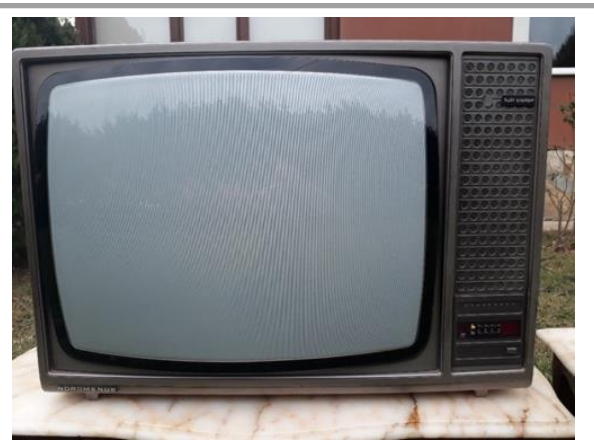

Fotoğraf 6: Katılımcı 89'un COVID-19 sürecinde hayatını zorlaştıran en önemli faktörle ilgili fotoğraf karesi

\begin{abstract}
Fotoğrafta ailemi görüyorsunuz onlarla yaşamanın avantajları olmasına rağmen zorlukları da var. Üniversiteli biri olarak bu zamanlarda genelde ailemden uzakta olurduk ve kardeşlerim de şimdi hepimiz evdeyiz ve dışarı çıkamıyoruz ve sıkılıyorum. Bence çok fazla dışarıya alıştığımız için artık biribirimizle olduğumuzda hemen sıkılıyoruz. hem mutlu hem de can sıkkınlığı hissediyorum. Ne yapabiliriz bilmiyorum ama aslında keşke ailem de otp'lere [Okuma- Tefekkür etme- Paylaşma grup bibliyoterapi] katılsaydı belki daha az malayani şeylerden konuşurlardı. belki onlar da bana ben de onlara bir şey katrdım hep aynı günlük işleri ve televizyonu konuşuyorlar sanırım bu canımı sıkıyor. Kardeşlerim de ben de internette çok fazla zaman geçiriyoruz sonra günn sounda bakıyorum bir şey yok. Yani ouldayken de çok düzenli bir programım yoktu ama sanırım şidmi daha da altüst oldu. Bir tek şey biraz daha namazlarımı kılıyorum ama bunlarda istediğim gibi değil mesela annem gibi huzurla ve yavaş kılmıyorum ve hem bundan hem de bilmediğim diğer nedenlerden dolayı içimde hep bir huzur eksikliği hissediyorum ve daha sağlıklı besleniyorum ve tabi ki gereğinden çok uyuyoruma ama bu çok da kötü değil. Televizyonda malayani şeyler yayınlanmasın dini, psikolojik, sosyolojik ve taihi açıdan gerçekten faydalı şeyler paylaşılsın. Hepimiz bu noktada bir şeyler yapabiliriz mesele rtüke yazabiliriz.
\end{abstract}

Tema: "sosyal izolasyon, yalnızlık, aileyle yaşamak, televizyon, internet"

Sekizinci, zorlaştırıcı ana tema katılımcıların \%6'sı $(n=7)$ tarafından ifade edilen maneviyat/spiritüalizme yeterince sahip olamama veya maneviyatı pratik edememe olmuştur. Katılımcılar içsel bir huzur, şükür, sabır ve aşkınlık eksikliğinin ve yardıma muhtaç diğer insanlara yardım edememenin kendileri için en zorlayıcı mesele olduğunu belirtmiştir. Bazı diğer araştırmacılar da kişi için önemli olan spiritüel yani manevi bakış açısı ve ritüellerden uzak kalmanın özellikle zor zamanlardan geçen kişi için daha büyük sıkıntılara neden olabileceğini vurgulamıştır (Borasit vd., 2020; Kirman, 2020; Tanhan \& Francisco, 2019; Tanhan \& Strack, 2020).

Dokuzuncu zorlaştırıcı ana temadan 20. ana temaya kadar olan temalar, katılımcıların sadece $\% 2$ 'si ile \%5'i tarafından ifade edildiği ve makalede kelime sınırı olduğu için bu temalar kısaca ele alınmıştır. Dokuzuncu ana tema olan psikopatoloji yukarıda ikinci ana tema ile ilgili olduğu için ele alınmıştı. Onuncu ana tema, altı katılımcı (\%5) tarafından ifade edilen, kurum ve kuruluşların profesyonel hareket etmemesi olmuştur. Bu katılımcılar zorlu pandemi sürecinde çeşitli kurum ve kuruluşlardan daha profesyonel kararlar beklediklerini belirtmiştir. Başka araştırmacılar da benzer sonuçlar bulmuştur (Karataş, 2020; Tanhan vd., 2020). On birinci ana temada altı katılımc1 (\%5) pandemi sürecinde günlük hayatın akışında yer alan uyku, yemek, sosyalleşme, temizlik ve ibadet/dinlenme gibi normalde zorlanmadan yaptıkları işler için bir plan veya program takip edememekten ortada kalan işler ve alt üst olan günlük hayatlarından yakınmıştır. On ikinci ana temada dört öğrenci (\%3) pandemi sürecinde genellikle ders veya diğer ailevi işlerden dolay1 kendilerine zaman ayıramadıklarından yani kendinde/mindful olma eksikliğinden bahsetmiştir. Diğer araştırmacilar da yoğun pandemi sürecinde öğrencilerin kendini dinlemek için zaman 
ayıramadığını ve bunun sorun oluşturduğunu bulmuştur (Kürtüncü \& Kurt, 2020; Tanhan vd., 2020). On üçüncü ana temada dört katılımcı (\%3) köy veya kırsalda yaşamanın getirdiği altyapı, konut, su, sağlık, internet ve elektrik gibi konulardaki kısıtlllıklardan bahsetmiştir. Diğer araştırmacılar da benzer sıkıntıları ifade etmiştir (Kürtüncü \& Kurt, 2020; Tanhan vd., 2020).

Geriye kalan 14. ana temadan 21. ana temaya kadarki tüm temaların her birini sadece üç katılımcı (\%2) dile getirmiştir. On dördüncü ana temada katılımcılar sağlık alanında çalışan aile üyeleri ve kendileri için endişelendiklerini ifade etmiştir. Bazı araştırmacılar bu yüzden sağlık çalışanları ve ailelerine özellikle odaklanılması gerektiğini ifade etmiştir (Tanhan vd., 2020; Tuncay vd., 2020). On beşinci temada akademide yani üniversite yönetimindeki ve üniversite hocalarındaki empati eksikliğini, yani zorlu süreçten geçen öğrenciler olarak anlaşılmadıklarını, ifade etmişlerdir. Benzer şekilde Tanhan vd. (2020) de bu konuya değinmiştir. Bir sonraki, 16. Ana temada, katılımcılar diğer insanların izolasyon kurallarına uymadığını ve bunun kendi pandemi süreçlerini oldukça zorlaştırdığını ifade etmiştir. On yedinci temada katılımcılar sağlıksız beslenmeden bahsetmiş olup bunu hem özelde COVID-19 bağlamında (Gençalp, 2020; Karataş, 2020) hem de genel olarak üniversiteliler için ele alan başka araştırmacılar da olmuştur (Tanhan \& Francisco, 2019; Tanhan \& Strack, 2020).

On sekizinci ana temada katılımcılar özellikle eğitim durumu düșük olan bazı insanların temel izolasyon kurallarını anlamadığı ve bu yüzden kurallara uyamadığını ifade etmiştir. Tanhan vd. (2020) de bağlamsal koşullar göz önünde bulundurularak herhangi bir ayrımcilığa sebep olmayacak şekilde, okuma ve yazması olmayan, yaşı ilerlemiş, eğitim seviyesi düşük, okula gitmeyen mülteci veya göçmen gruplara, gerekli hizmetlerin en etkili şekilde ulaştırılması gerektiğini ifade etmiştir. Benzer şekilde Soysal (2020) da yaşın bir ayrımcılığa neden olmaması için yaşı ilerlemişlere pandemi sürecinde hizmetlerin hassasiyetle sağlanması gerektiğini vurgulamıştır. On dokuzuncu ana temada öğrenciler özellikle de dışarıda spor veya egzersiz yapmanın öneminden bahsederek dışarda spor/egzersiz yapamamaktan yakınmışlardır. Diğer bazı araştırmacılar da fiziksel olarak aktif olmanın pandemi sürecindeki öneminden ve izole olmanın olası zararlarından bahsetmiştir (Akyol vd., 2020; Gumusgul \& Aydoğan, 2020; Tanhan vd., 2020). Yirminci temada ise katılımcılar evde sürekli televizyonun açık olması, pandemi ile ilgili haberlerin izlenmesi ve tüm bunların kendilerini rahatsız etmesi ve diğer günlük işleri aksatmasını rapor etmiştir. Son olarak 14 katılımcı hikâyelerine ve fotoğraflarına tema vermediği için bu hikâye veya fotolar 21 . "Diğer" ana teması altında toplanmıştır.

Özetle, zorlaştırıcı temalar 21 ana temada toplanmıştır. Kolaylaştırıcı ve zorlaştırıcı ana temalar beraber düşünüldüğünde ve karşılaştırıldığında da ortak bazı temaların olduğu görülebilir. Yani online/uzaktan eğitim veya aile ile yaşamak gibi bazı ana temalar bazı katılımcılar için oldukça kolaylaştırıcı iken bazıları için de zorlaştırıcı olmuştur. Bu da aslında o temanın ne kadar önemli olduğunu gösteriyor olabilir. Bunlara ek olarak analizleri yapanlar ana tema olarak ortaya çıkmasa da beş temel önemli noktanın ele alınmasını önemli görmüştür: (1) Genelde medyada ve özellikle de sanal medyada sunulan ve insanların panikleyeceği ve birbirine karşı anlayışsız davranacağı gibi provakatif ve kaos haberlere karşın böyle bir ana tema ortaya çıkmamıştır. Tam tersine genel olarak katılımcılar kendilerine ve diğer insanlara olabildiğince anlayışla yaklaşmış ve önemli bir kısmı da hikâyelerinin satır aralarında diğer insanlara istedikleri kadar yardımcı olamadıkları için de üzüldüklerini ifade etmiştir. (2) Erkek katılımcılar kadın katılımcılara göre dışarı çıkamamaktan daha fazla yakınmıştır. Aynı zamanda, erkeklerden bazıları da bugüne kadar yapmadıkları ev içi işleri yapmaya başladıklarını ve bunu eğlenceli bulduklarını ifade etmiştir. Aynı zamanda erkek katılımcılardan bazılarının da bugüne kadar yapmadıkları ev içi işlerini yapmaya başladıklarını ve bundan eğlendiklerini ifade etmiştir. (3) Kadınlar ev işleri ve fazla misafir ziyaretinden erkeklere göre daha fazla yakınmıştır. Yine kadınlar erkeklere göre hem anne, baba ve kardeşler arasında yani aile içi hem de ikili (örn., evli, nişanlı, romantik) ilişkilerde pandemi sürecinde hafif düzeyden ağır düzeye kadar değişebilen çatışma sorunlarından bahsetmiştir. Kadınlar bu konularda hem kendileri 
ve özellikle de erkekler için online ruh sağl 1 ğ hizmeti ve ilgili kişi, kurum ve kuruluşların da bu noktada daha etkili hizmet vermesini talep etmişlerdir. Bu da insanlık tarihinde tartışlagelmiş geleneksel rollerin insanların kendi mağaralarına yani evlerine çekildiği pandemi, endemi ve güvenlik gibi sorunların yaşandığı süreçlerde kadın ve erkek rollerinin nasıl değişebileceği de tartışmaya açabilir bir nokta gibi gözükmektedir. Başka araştırmacılar da özellikle kadınlar için benzer sonuçlar bulmuştur (Demir Öztürk vd., 2020; Zeybekoğlu Akbaş \& Dursun, 2020). (4) Bazı katılımcılar pandemiye ve virüse inanmadıklarını bunun küresel güçlerin insanları sömürmek için bir araç olduğunu ve sömürmeye kısa bir ara verirken online yollarla yani farklı yollarla bu sömürüyü arttırdıklarını ifade etmişlerdir. Topuz (2020) ve Tanhan vd. (2020) de pandeminin ezilen kitleler için daha fazla sömürü ve ezilmeye yol açabileceğine işaret etmiş̧ir. (5) Katılımcılar, COVID-19 sürecini geçirdikleri şehirlerde zorunlu sokağa çıkma yasaklarından hemen sonra insanların pandemi bitmiş gibi rahat bir şekilde dışarı çıktığını gözlemiştir. Bu da sadece otoriter kurallar yerine çok daha esnek ve insanları olabildiğince fiziksel izolasyona motive edecek etkili, nazik, mizahi ve profesyonel hizmetlerle toplumun kendisini de işin içine katarak toplumun kendi prensiplerini oluşturmasını sağlamanın önemini göstermektedir. Pandemi süreci uzadıkça ve toplumun biyopsikososyal manevi ve ekonomik genel iyi oluş düzeyi düştükçe böyle profesyonel ve toplum tarafından içselleştirilmiş prensiplere olan ihtiyaç artacak gibi gözükmektedir. Tanhan vd. (2020) bu konuya değinmiş ve kısa, orta ve uzun vadede pandeminin yayılmasını önlemek, ortaya çıkan meseleleri ele almak ve genel iyi oluş düzeyini artırmak için bağlamsal ve teorik olarak iyi düşünülmüş online ruh săglı̆̆ı gibi hizmetlerin önemini vurgulamıştır. Araştırmanın öneriler kısmında kolaylaştırıcı ve zorlaştırıcı ana temalar bütüncül ve bağlamsal bir perspektiften ele alınarak yapılabileceklerin bir kısmı ifade edilmiştir. Bütüncül ve bağlamsal bir perspektiften bakmayan araştırmacı, uygulayıcı ve yöneticilerin bağlamdışı tutum, düşünce ve davranışları insanları bilerek veya bilmeyerek dışlama, ezme ve marjinalleştirmeye yol açabilir (Tanhan \& Francisco, 2019; Tanhan \& Strack, 2020). Bu araştırmacılar böyle durumların yani bağlamın göz önünde tutulmamasının, çok radikal bir düşünce bile olsa, evrensel insan haklarıyla uyuşmayan oldukça etik dışı sonuçlar doğurabildiğini dile getirmiştir.

\section{Katılımcı ve paydaşlarla sonuçları paylaşmak ve aktif sosyal savunuculuk yapmak}

Bulguların tartışılması kısmında bu ikinci noktada ele alınacak bulgular katılımcılardan gönüllü olanlarla beraber sonuçları online yollarla ilgili ve yetkili kişi ve kurumlara (valilik, belediye, rektörlük, Diyanet İşleri Başkanlığı, MEB, sağlık kuruluşları ve bakanlıklar) ulaştırılmaya çalışılmıştır. Yaşamı kolaylaştıran faktörleri ihtiyaç duyulan düzeyde artırmak ve zorlaştıran faktörleri etkili bir şekilde ele alarak meselelerin çözüme kavuşturulması için ilgili ve yetkili kişi, kurum ve kuruluşlara ulaşarak aktif sosyal savunuculuk yapılmıştır. Pandemi sürecinden dolayı yavaşlamış olsa da aktif savunuculuk için gerekli adımlar atılmaya devam etmektedir ve olumlu sonuçlar alınmaktadır. Araştırmanın sonuçlarının paylaşıldığ 1 ve diyalogların kurulduğu sosyal/sanal gruplara da katılan kişi sayısı ile ilgili kişilerin bu gruplara yönelik ilgisi artmaktadır. Buna ek olarak, araştırmanın sonuçlarına ilgili olan birçok katılımcı ve diğer insanlar sonuçları merak etmiş ve araştırma için kurulmuş sanal medya grubuna katılmak istemiştir. Ancak Türkiye'nin genel bağlamı düşünüldüğünde sanal medyada ve gruplar üzerinde hükümet düzeyinde yapılan açılamalar, tartışmalar ve geçmişteki bazı olaylar bu kişileri güvenlik gerekçelerinden dolayı katılmaktan kaygılandırmış ve birçoğu katılmamıştır. Bundan dolayı sonuçlar yukarıda ifade edilen internet adresinde de sürekli açık erişime açılmış ancak kritik bir diyalog platformu oluşturulmamıştır. Başka önemli bir nokta ise özellikle birçok katılımcı sonuçların paylaşıldığı Facebook platformunun Instagram'da oluşturulması için yoğun istekte bulunmuştur ancak Instagram'ın Facebook kadar kritik diyaloglara elverişli olmamasından bu istek yerine getirilememiştir. Bu sonuç da üniversite öğrencilerinin Facebooktan Instagrama kaydığına işaret ediyor olabilir. Bazı araştırmacılar devlet üniversiteleri (Samur, 2020) ve tiyatrolarının (Kart, 2020) ve benzer diğer ulusal ve uluslararası kuruluşların (Aldemir \& Avşar, 2020) bu pandemi sürecinde sanal medya hesaplarını aktif bir şekilde

Turkish Studies, 15(4) 
kullandığını vurgulamıştır. Ayrıca bu hesapların daha aktif bir şekilde de kullanılabileceğine yönelik önerilerde bulunmuşlardır.

Başka araştırmacılar da sosyal adalet için ruh sağlığı uzmanlarının eğitim ve araştırmalarında savunuculuğu önemli görmüştür (Dollarhide vd., 2016; Kalkan \& Can, 2020; Tanhan, 2018). Tüm bunlara dayanarak ve Tanhan ve Strack (2020)'in önerdiği ve kısmen online olarak yaptığı aktif savunuculuk mevcut araştırmada çok daha etkili bir şekilde yapılmaktadır. Mevcut araştırmada fiziki olarak da ilgili kişi ve kurumları ziyaret etme safhası, bu araştırma yazılıncaya kadarki zamanda, birkaç kişi ve kurumla sınırlı kalmış olmakla beraber devam etmektedir.

\section{Kolaylaştırıcı ve zorlaştırıcı faktörlerin Ekolojik Sistemler Teorisi (EST) çerçevesinde hangi düzeylerle ilgili olduğunu belirlemek.}

Tartışmanın bu bölümünde katılımcıların en önemli faktörleri EST'nin hangi düzeylerine atfettiği ele alınmıştır. Katılımcılar bir faktörü birden çok sisteme atfedebilmiştir. Çünkü kolaylaştırıcı veya zorlaştırıcı faktörlerin oluşmasında tüm sistem düzeyleri senkronize bir şekilde işler (Tanhan, 2019; Tanhan \& Francisco, 2019). Katılımcıların kolaylaştıııcı $(\% 86, n=97)$ ve zorlaştırıcı $(\% 76, n=86)$ temaları en çok kendi bireysel/içsel biyopsikososyal manevi ve ekonomik kaynaklara yani bedensel his, duygu, düşünce, tutum, davranış, inanç, değer ve maddi kaynaklarına atfettikleri görülmektedir. Daha sonra ise en çok ekzosistemlere (kolaylaştırıcı: \%46, $n=52$ ve zorlaştırıcı: $\% 58, n=65$ ) yani toplumdaki medya, komşular, sosyal hizmetler, yerel yönetimler ve yerel kuruluşlara atfetmişlerdir. Üçüncü sırada ise hükümet, ekonomi ve bakanlıklar gibi faktörlere yani makrosistemlere atfetmişlerdir: Kolaylaştırıcı ( $\% 35, n=40)$ ve zorlaştırıcı $(\% 54, n=48)$. En az ise okul, aile ve yakın çevre gibi mikrosistemlere atfetmişlerdir: Kolaylaştırıcı $(\% 10, n=11)$ ve zorlaştırıcı $(\% 71, n=80)$. Bir sonraki paragrafta daha detaylıca ele alındığı gibi bireysel düzeydeki faktörler ve mikrosistemler beraber tek bir düzey olarak da düşünülebilir.

Araştırma literatürde bu şekilde atfetmeyi ele alan ilk araştırma olmakla beraber bu sonuçlar Tablo 1 ve 2'deki kolaylaştırıcı ve zorlaştırıcı ana tema sonuçlarını üç açıdan anlamlı bir şekilde desteklemektedir. (1) Bireysel/içsel faktörler ve mikrosistemler aslında oldukça iç içedir ancak EST'de bireysel/içsel diye bir faktör olmadığ 1 , mikrosistem bireyi de içerdiği ve en önemlisi de araştırmacının uzmanlık alanı olan ruh sağlığında bireysel/içsel faktörler de en az diğer sistemler kadar önemli olduğundan bu araştırmada bireysel/içsel faktörü ayrı bir düzey olarak eklenip sorulmuştur. $\mathrm{Bu}$ açıdan bireysel/içsel ve mikrosistemlere atıflar beraber düşünülüp hikâye ve ana temalara bakıldığında sonuçlar daha anlamlı gelmektedir çünkü birçok katılımcı en önemli faktörler olarak bu sistemlerin altına düşen kolaylaştırıcı (örn., kendindelik, aile/akraba, maneviyat) ve zorlaştırıcılardan (örn., aile ile olamamak, psikolojik meseleler) bahsederek kendilerini merkeze almışlardır. (2) Diğer taraftan katılımcıların ana temalarından yine ön sıralarda yer alan kolaylaştırıcı ve zorlaştırıcıların ekzosistem (örn., medya, internet, yerel düzenleme ve yasaklar, çarpık kentleşme ile gelen doğadan uzaklaşma, kurum ve kuruluşların yaklaşımı, altyapı yetersizlikleri) ve makrosistem (örn., ulusal düzeydeki düzenleme ve yasaklar, ekonomik meseleler, eğitim) düzeylerinin altına düştüğü gözükmektedir. (3) Araştırmacılar EST'de daha genişs sistemlerden yani makrodan bireysel/içsel faktörlere doğru gittikçe etki oranının düştügünü vurgulamışlardır. Başka bir deyişle, makrosistemlerin bir alttaki sistemler, örneğin bireysel/içsel faktörler veya mikrosistemler üzerindeki etkisi bireysel faktör veya makrosistemlerin makrosistemler üzerindeki etkisinden çok daha güçlüdür (Tanhan, 2019; Tanhan \& Francisco, 2019; Tanhan vd., 2020). Aynı şekilde bu yazarlar uygulayıcı ve araştırmacıların özellikle de eğitim, ruh sağlığı ve tıp gibi birçok alanda önemli olguları (örn., sağlık, fakirlik, şiddet, eğitim durumu) bağlam/kontekst içinde ele almaktan ziyade bireysel/içsel sistemlere indirgediğini yani medikalizasyonlaştırdığını vurgulamışlardır. Bu durumun da çok güçlü olan makrosistemlerin ele alınmasını bilinçli veya bilinçsiz bir şekilde unutturduğu ve daha kompleks meselelere neden olduğu noktasında uyarıda bulunmuşlardır. Hem bu açıdan hem de EST'nin son eklenen sistemi olan kron sistemin yani zamanın 
diğer tüm faktörler üzerindeki etkisi düşünüldüğünde Türkiye'deki şu anki üniversite nesli düşünüldüğünde makrosistemlerden çok daha fazla bireysel/içsel ve mikrosistemlere atıfta bulunmaları çok daha anlamlı gelmektedir. Bunun temel nedeni mevcut eğitim, medya, yönetim, ekonomi gibi birçok hizmet ve alanda makrosistemler yerine bireyselliğe ve mikro faktör ve perspektife ağırlık verilmesi olabilir.

Araştırmacı ilk defa OSF ile katılımcıların faktörleri EST perspektifinden hangi sistemlere atfettiklerini incelemiştir. Ortaya çıkan sonuçlar araştırmanın teorik çerçevesi açısından anlamlı sonuçlar oluşturmuştur. Bu adımın ilk defa yapılmış olması da alanyazına ve araştırmaya özgün bir değer katmaktadır.

4. OSF'nin Türkçe olarak orijinaline uygun bir şekilde uyarlanması ve kullanılması

Araştırma bulgularının tartışılmasında son ve dördüncü nokta ise OSF’yi aslına uygun olarak Türkçe'ye uyarlamak ve kullanmaktır. Geleneksel seslifoto tekniğinin bağlama göre uyarlanması gerektiğini birçok araştırmacı söylemiştir (Karne vd., 2013; Tanhan \& Francisco, 2019; Tanhan \& Strack, 2020; Tanhan vd., 2020). Tanhan ve Strack (2020) geleneksel seslifotonun OSF versiyonunu geliştirerek tekniği çok daha avantajlı bir duruma getirmiştir. Bu mevcut araştırmanın yazarı ise OSF'nin Türkçe olarak orijinaline uygun olarak geliştirilmesi ve Tanhan ve Strack'in önerdiği atfetme basamağını ekleme ve aktif savunuculuğu online yollarla gerçekleştirme gibi bazı noktaları da ekleyerek orijinal OSF'yi uygun bir şekilde Türkçe'ye uyarlamıştır. Ayrıca yazarın OSF'nin Türkçe uyarlamasını tüm dünyayı çok ciddi düzeyde etkileyen COVID-19 pandemi sürecinde bu mevcut araştırmada etkili olarak kullanması literatüre özgün bir değer katmıştır.

Araştırmada katılımcıların genel olarak katılımının yüksek olması, araştırmayı tam olarak doldurması, birçoğunun araştırmayı eğlenceli ve ilgi çekici bulması, araştırma için araştırmacıya teşekkür etmesi ve araştırma sonuçlarını online yollarla ilgili kişi, kurum ve kuruluşlara ulaştırmak için aktif sosyal savunuculuk yapması OSF'nin Türkçe'ye uygun bir şekilde uyarlandığını ve etkili olduğunu göstermektedir. Ayrıca ortaya çıkan ana temaların kendi içinde ve COVID-19 literatürüyle uyumlu olması ve ilgili literatüre yeni özgün değer katması de araştırmanın etkili bir şekilde uyarlandığına işaret etmektedir.

OSF tekniği gereği temel beş duyuyu (örn., görme, dokunma) ve diğer hareket etme, yer-yön gibi birçok farklı duyuyu da içerdiğinden diğer birçok araştırma tekniğine göre daha avantajlıdır (Tanhan \& Strack, 2020). İnsan, doğası gereği görsel uyaranlara, görsel uyaran içermeyen uyaranlara göre çok daha hassas ve ilgilidir. Mevcut araştırmanın sonuçları katılımcı ve yetkili kişilerle paylaşıldığında tüm katılımcı ve yetkili kişiler görsel fotoğraflara ve onlara eşlik eden hikâye ve temalara çok daha fazla odaklanmış ve onların üstüne daha derin diyaloglar geliştirmiştir. Tüm bunların yanında OSF'nin düşünme, tefekkür etme, yazma ve paylaşma gibi zihinsel süreçlerin birçoğunu içeriyor olmasının da bu tekniği diğer birçok tekniğe göre çok daha avantajlı kılmaktadır. Özetle, OSF'nin Türkçe versiyonunun bağlamsal ve işlevsel olarak etkili bir şekilde uyarlandığı ve kullanıldığı söylenebilir.

\section{Sinırlılıklar}

Araştırma sonuçları ve bir sonraki kısımda ele alınan önerilerin araştırmanın sınırlılıkları çerçevesinde değerlendirilmesi faydalı olacaktır. Bu araştırmanın en önemli sınırlılığı araştırmanın online ve COVID-19 bağlamında uygulanmış olmasından dolayı katılımcıların yalnızca uygun elektronik cihazlara sahip kişilerden seçilmesidir. Uygun elektronik cihazı olmayan kişilere gerekli imkânlar sağlanamadığı için bu kişiler araştırmaya çok büyük bir ihtimalle katılım sağlayamamıştır. Araştırmacı bazı katılımcıların kamerası iyi olan bir cihaza sahip olmaması, COVID-19 sokağa çıkma yasakları ve dışarıya çıkmanın getireceği virüsün bulaşması tehlikesinin bazı katılımcıları internetten hazır fotoğraf bulma, indirme ve kullanmaya yönlendirdiğini düşünmektedir. OSF'de 
katılımcılara kendi fotoğraflarını kendilerinin çekmesinin anlam ve avantajları anlatılmakla beraber herkese açık olan ve başkasının hakkına ve gizliliğine yani hakkı saklıdır etik kurallarına uyularak internetten de fotoğraflar kullanılabilir. İkinci önemli sınırlılık ise, sonuçların Tanhan ve Strack (2020)'in önerdiği şekilde fiziki bir sergi ve sosyal etkinlikte ilgili kişi, kurum ve katılımcılarla paylaşılamamış olmasıdır. Bunun yerine sadece sanal medyada ve diğer online yollarla paylaşım ve aktif sosyal savunuculuk yapılmıştır. Bir diğer sınırlılık, araştırmaya katılımın Türkiye'nin doğusunda yer alan bir devlet üniversitesindeki 10 farklı fakülteden 127 öğrenci ile sınırlı olmasıdır. Son olarak, bu araştırmada katılımcılardan COVID-19 sürecinde, spesifik olarak eğitim gibi bir konu yerine daha genel olarak, hayatlarını kolaylaştıran ve zorlaştıran en önemli birer faktör paylaşmaları istenmiştir. Bu temel sınırlılıkların yanında OSF yönteminin ilk defa Türkçe'ye uyarlanması ve kullanılması, araştırmaya katılma için verilen zaman ve COVID-19 bağlamı düşünülmelidir. Ayrıca katılımcılardan kolaylaştırıcı ve zorlaştırıcı için en az bir en fazla üç tema istenmiş ancak bazı katılımcılar üçten daha fazla tema belirtmiştir. On dört katılımcı da hiçbir tema belirtmemiştir. Bu ve diğer olası sınırlılıklar 1şığında aşağıdaki öneriler düşünülebilir.

\section{Öneriler}

$\mathrm{Bu}$ araştırmanın yukarıda sayılan sınırlılıkları göz önünde bulundurularak elde edilen bulguların araştırma, hizmet verme, eğitim ve aktif sosyal savunuculuk gibi dört temel alanda önemli uygulamaları olabilir. Bu dört alanda da mevcut araştırmanın sonuçları adapte edilen ve kullanılan OSF’ye, bağlamsal şartlara ve ele alınan konuya göre gereken değişiklikler de yapılarak kullanılabilir. Bu gereken değişikliklerin yapılması önemlidir çünkü OSF’nin en temel amacı sesi kıstırılmış ve perspektifi anlaşılmamış özellikle de sömürülerek marjinalleştirilmiş insanların genel iyilik hâllerini ve bazı araştırmacıların değindiği gibi psikolojik sağlamlıklarını (Akar \& Aktan, 2020; Tanhan vd., 2020) artırmaktır. Genel iyilik hâli ve/veya psikolojik sağlamlık sadece bir kişi, grup, kurum ve/ya kuruluş yerine EST'de yer alan tüm sistemlerin harekete geçirilmesi ve kapasitelerinin artırılması ile mümkün olabilir (Tanhan \& Francisco, 2019; Tanhan \& Strack, 2020). $\mathrm{Bu}$ açıdan aşağıdaki uygulama önerileri düşünülebilir.

\section{Araştırma Alanındaki Uygulama Önerileri}

Gelecek araştırmalarda OSF'nin birçok konuda uygulaması olabilir. Bu açıdan, COVID-19 sürecinde genel sağlık, halk sağlı̆̆ı, ruh sağlığı, eğitim, sosyal hizmetler, iletişim, mühendislik, mimarlık, sanat, spor, finans ve hukuk gibi birçok farklı alanda kısa, orta ve uzun vadede topluma o alanda daha etkili hizmet vermek için OSF tekniği kullanılarak araştırmalar yapılabilir. İkinci bir araştırma ise yukarıda sayılan alanlarda çalışarak halkın geneline hizmet veren uzmanlarla, özellikle de genel sağlık gibi alanlarda ön sıralardan hizmet veren uzmanlarla yapılabilir. Üçüncü bir genel araştırma konusu ise daha özel odak gruplarla OSF'yi kullanmak olabilir. Örneğin mülteciler, göçmenler, ekonomik durum, cinsellik, cinsiyet, cinsel yönelim, din, dil ve ırk gibi farklı açılardan sömürülmüş, marjinalleştirilmiş̧, sesi kısılmış ve kendi yaşamları ve genel yaşam hakkında bakış açıları dinlenilmemiş kişi veya gruplar. Bu araştırma önerisi ile ilgili olarak OSF bağlama göre uyarlanarak daha spesifik olarak ilkokul, ortaokul ve lise düzeyindeki çocuk veya ergen öğrencilerle kullanılabilir.

Benzer şekilde araştırmacılar OSF'yi üniversiteli öğrencilerin biyopsikososyal manevi ve ekonomik genel iyilik hâlini artırmak için tek başlarına ya da benzer ana bilim dalları bazında (örn., psikolojik danışmanlık ve rehberlik, psikoloji, sosyal hizmet; islami ilimler ve ilahiyat) da uygulayabilir. Dördüncü ve özellikle mevcut araştırmanın sonuçlarıyla doğrudan alakalı olarak, gelecekteki araştırmacılar mevcut araştırmada ortaya çıkan kolaylaştırıcı ve zorlaştırıcı ana temaların her biri için ve özellikle de katılımcılar tarafindan en fazla ifade edilmişlerden başlayarak ayrı ayrı OSF araştırması yapabilir. Bu katılımcılar tarafından da önerilen bir araştırmadır. Çünkü katılımcıların çoğu ifade ettikleri temayla ilgili daha fazla fotoğraf gönderebileceklerini ve daha fazla açıklama yapabileceklerini söylemişlerdir. Ayrıca bu ana temalara bu şekilde odaklanıldığında, her 
bir ana temada birkaç kişi yerine yüzlerce kişi yer aldığında, yüzlerce biricik farklı ve zengin perspektif ortaya çıkabilir ve spesifik ana temada yüzlerce kolaylaştırıcı ve zorlaştırıcı ortaya çıkabilir. Tüm bunlar da genel iyilik hâlini artırmak için çok daha derin ve zengin bir aktif sosyal savunuculuk süreci oluşturabilir. Bunların yanında başka önemli bir konu da özellikle de eğitim, ruh sağlığı ve sosyal bilimlerde Türkiye'de deneysel veya yarı deneysel araştırmaların az olması ve var olanların da genelde nicel olmasıdır (Arslan vd., 2020; Çiçek vd., 2020; Tanhan, 2018; Tanhan vd., 2020). Bu açıdan insanları hiç yönlendirmeyen veya nicel araştırmalara göre çok daha az yönlendiren, OSF ve benzeri, inovatif nitel teknikler deneysel ve yarı deneysel araştırmalarda yapılan müdahâlelerin etkisini görmek için kullanılabilir. Son bir öneri de bu çalışmada yapıldı̆̆ 1 gibi OSF'nin özellikle dünyada en çok konuşulan Çince, İspanyolca, Arapça, Hintçe, Bengalce, Portekizce ve Rusça gibi diller başta olmak üzere bu dillerde de OSF'nin etkisi ve ruhu korunarak kullanılacak şekilde uyarlanabilir. Bu uyarlamada OSF birebir çevrilmesinden ve uyarlanmasından ziyade OSF'nin ruhunu koruyacak ve kullanımını bağlamsal olarak daha da etkili yapacak şekilde bu dillere kazandırılmasına dikkat edilmesi gerekir.

\section{Hizmet Verme Alanlarında Uygulama Önerileri}

Psikometrik özelliklere sahip olsa da nicel veya nitel birçok ölçme aracı aslında bir bakıma kişiyi manipüle de edebilmektedir. Bireyin zihinsel sürecinde olmayan bir kavram soru sorularak oluşturulabilir. Bu açıdan kişiyi daha az manipüle edici OSF'nin insanlara birebir hizmetin verildiği alanlarda hem genel hem de spesifik olarak COVID-19 sürecinde önemli uygulamaları olabilir. Sağlık, pazarlama, eğitim gibi hizmet verme alanlarında ilk OSF uygulaması hizmet alan kişinin farklı aldığı hizmet kalitesinin sürecini anlatması, şekillendirmesi ve kolaylaştırıcı ve zorlaştırıcıları bu hizmetleri sağlayan uzmanlarla beraber ele alması önemli bir uygulama olabilir. Bu hizmet alanlarının başında bedensel sağlık, ruh sağlığ hizmet vermeye geniş anlamda eğitim, pazarlama, finans gibi insanlara hizmet vermeyi içeren tüm alanlar da girmektedir. Özellikle de COVID-19 ile beklenmedik şekilde değişen yaşam ve dünya paradigmalarına bu hizmet sektörlerinin en uygun şekilde ayak uydurması için tepeden ve hizmet alanların perspektiflerinin çok az alındığı veya hiç alınmadığı geleneksel uyum araştırmaları gözükmektedir. Bir veya birkaç kişinin karar verdiği böyle alışılagelmiş yaklaşımlar yerine sektörlerin hizmet verdikleri kişileri yeni uyum sürecine baştan sona OSF’nin önerdiği gibi katmaları sektör, hizmet alanlar ve tüm toplum için daha anlaml, hassas ve üretken süreç ve sonuçlar oluşturabilir. Örneğin, genel biyomedikal sağlık ve toplum ve ruh sağlığı uzmanları hizmet verdikleri kişilerle OSF'yi kullanarak onların kendi biricik perspektiflerinden anlaşılmalarını kolaylaştırabilir, hizmet sürecini ve mekânlarını ona göre şekillendirebilir.

İkinci bir uygulama da mevcut araştırmanın sonuçlarıyla ilişkili olarak farklı alanlarda hizmet veren profesyoneller ve ilgili kişi, kurum ve kuruluşlar, özellikle de üniversite yönetimleri tarafından gerçekleştirilebilir. Bu kişiler ve kurumlar, mevcut araştırmada ortaya çıkan kolaylaştırıcı ve zorlaştıııcı ana temalardan kendi alanlarıyla ilgili olanlara odaklanıp genel iyilik hâlini tüm insanlar için arttırmaya çalışabilir. Özel birkaç örnek şöyle olabilir: (1) Yerel yönetici, kurum ve kuruluşlar doğadan uzak, çarpık ve beton kentleşme ve köy veya kırsal bölgelerdeki alt yap1 yetersizliklerini ifade eden ana temalara odaklanıp bunları ivedilikle ele alabilir. (2) Sağlık çalışanları sadece indirgemeci/biyomedikal bir modelden ziyade bütüncül bir biyopsikososyal manevi ve ekonomik bir perspektiften genel sağlığı etkileyen durumları anlamaya çalışabilir ve bunu yaparken de EST'nin her bir düzeyinin etkisini de göz önüne alıp gereken sistemik/bağlamsal değişiklikler için diğer kurum ve kuruluşlarla çalışabilir. (3) Hizmet sektöründeki son uygulama örneği olarak, ruh sağlığı çalışanları bağlamsal olarak daha işlevsel online ruh sağlı̆̆ hizmetleri geliştirebilirler. Meselelerin oluşması ve etkili olarak ele alınabilmesi için tüm bu ana temaların farklı oranlarda da olsa etkili olduğunu bütüncül bir biyopsikososyal manevi ve ekonomik perspektiften düşünebilirler. Böylece sadece indirgemeci/medikal bir perspektiften ziyade daha bağlamsal ve sistemik hareket edebilirler. Bu konuda bazı araştırmacıların önerdiği gibi EST bağlamında kabul ve kararlılık terapisi 
(KAT) kullanılabilir (Arslan vd., 2020; Tanhan, 2019; Tanhan vd., 2020). Bütün bunlara ek olarak araştırmanın teorik çerçevesi açısından olmazsa olmaz bir uygulama da tüm hizmet sektörlerini şekillendiren, makrosistem düzeyinde yer alan ulusal yönetimin yani hükümetin ana temalarla ilgili yasal düzenleme ve destekleri ivedilikle harekete geçirerek daha az kapasitesi olan ve alt mikrosistem ve ekzosistemlerde bulunan kişi, kurum ve kuruluşlarının hareket alanı ve kapasitesini genişletmektir.

\section{Eğitim Alanında Uygulama Önerileri}

Geçmiş pandemi, endemi ve şu an hâla devam etmekte olan COVID-19 süreçlerinde hemen hemen tüm ülkelerde en fazla etkilenen alan eğitim olmuştur. Türkiye'de de milyonlarca öğrenciyi, aileyi ve eğitimciyi etkileyen ve ülkenin geleceğini şekillendiren eğitimciler uzaktan veya online eğitimi planlarken öğrencilerin biyopsikososyal manevi ve özellikle de ekonomik bağlamlarını yani mevcut araştırmada elde edilen ana temaları da hesaba katarak bağlamsal, bütüncül ve işlevsel çözümler oluşturabilir. Bütüncül ve bağlamsal bir perspektiften yani EST'nin eğitimde kullanılmasını bazı araştırmacıları vurgulamıştır (Arslan \& Tanhan, 2019). Bütüncül bir bakış açısından bakmayan araştırmacı ve hizmet veren kişilerin insanlara sadece gereken hizmeti vermemesi bir yana bu kişiler hizmet verdikleri kişileri bilerek veya bilmeyerek dışlayabilir, ezebilir ve marjinalleştirebilir (Tanhan \& Francisco, 2019; Tanhan \& Strack, 2020; Tanhan vd., 2020). Örneğin, sosyoekonomik olarak zor durumda olan öğrencilere online/uzaktan eğitim için gereken elektronik cihazları daimî veya geçici bir şekilde sağlamak; köyde, kırsalda veya yaşadığı yerde eğitimini istediği ve gereken şekilde alamayan öğrencilere kampüslerde veya şehirde uygun konaklama yeri sağlamak ve tüm yurtları tümden kapatmamak bazı çözüm yolları olabilir. Kendi özel uygun konaklama koşullarına sahip olmayan öğrencilere özellikle de pandemi, endemi veya çatışma ve şiddet gibi güvenlik meselelerinin oluştuğu süreçlerde üniversite yerleşkelerinde yer alacak konaklama yerlerini üniversiteler buna göre düzenleyebilir. $\mathrm{Bu}$ konuda en önemli çözümlerden birisi bütüncül ve interdisipliner çalışarak onlarca katlı beton bloklar yerine doğanın içinde bir veya en fazla üç katlı birbirinden çok uzak olmayan konutlar inşa etmek olabilir. Benzer şekilde, bazı katılımcıların da ifade ettiği gibi, binaların rahatça ve bolca doğal yollarla hava alması ve sirkülasyonun vantilatör olmadan sağlanması için yollar bulunmalı: büyük pencereler, tüm pencerelere sineklik takılması (böylece pencereler sürekli açık kalabilir), havalandırma yollarının artırılması, geniş ve mümkünse doğa ile iç içe sınıflar, doğanın içinde kütüphaneler, tek veya birkaç kişilik çalışma odaları yapılabilir. Bunlara ek olarak da insanların yoğun bulunduğu lavabo, merdiven ve koridor gibi yerlerde, birden çok giriş ve çıkışın, oldukça geniş ve vantilatörlere gerek bırakmadan doğal olarak hava ve ışığın akışının sağlayan tamamen açılabilir pencere veya kapıların yapılması da oldukça önemli olacaktır. Son olarak gerek eğitim kurumları gerek alış veriş merkezleri gibi toplu yaşam yerlerinde insanların molaya çıkmasının sırayla yapılması da önemli olacaktır. Yani tüm öğrenci ve çalışanlar normal zamanlardaki gibi herkesin aynı anda ders veya işbaşı yapması, işe ara vermesi ve işi bitirmesi yerine belli bir düzen çerçevesinde ayrı ayrı küçük gruplar şeklinde iş başı yapma, ara verme ve bitirme önemli olacaktır. Böylece olası pandemi veya güvenlik sorunları gibi insanların dışarıya çıkmasının zor olduğu durumlarda bile öğrenciler güvenli bir ş̧ekilde yerleşkelerinde kalabilir, hâla bir topluluk/grubun üyesi olduğu yaşantısını sürdürebilir, fiziksel ve sosyal prensiplere de uyarak mümkün olan maksimum düzeyde bireysel ve eğitim yaşamını sürdürebilir. Fiziksel mesafeye dikkat ederek bir topluluğun üyesi olma temel ihtiyacının giderilmesi tüm insanlar için hayatidir çünkü biyopsikososyal manevi ve ekonomik hayat için çok zararlı olan sosyal izolasyona, özellikle de uzun süre, maruz kalmamak insanın en temel ihtiyaçlarından birisidir (Tanhan vd., 2020). Eğitimde başka önemli bir uygulama da COVID-19 gibi beklenmeyen hızlı kararlarla acil uzaktan/online eğitime geçilen ve özellikle de öğrencilerin biyopsikososyal manevi ve ekonomik bağlamı öğrenciyi zorladığında izlenecek bazı çözümler şöyle olabilir: Az ve çoktan seçmeli ödev vermek, öğrencilere kendine ve diğerlerine şefkat/merhametle yaklaşmak gibi profesyonelce hazırlanmış ödev vererek zorlu süreçte anlamlı ve etkili bir şeyler yaptırmak ve süreci 
kolaylaştırmak, sınav yerine yapılabilir proje ödevleri, harf notu ile geçme yerine kaldı geçti, ödev teslimi ve ders kayıtlarına erişim için dönem bittiğinde bile olabildiğince zaman vermek ve tüm idare ve akademik süreçte öğrencilere karşı olabildiğince empati ile yaklaşmak.

\section{Aktif Sosyal Savunuculuk Alanında Uygulama Önerileri}

Günümüzde globalleşmeyle beraber her alanın kendi içinde bile mikro düzeyde uzmanlaşmaya gittiği düşünüldüğünde bütüncül bir biyopsikososyal manevi ve ekonomik perspektiften EST'nin her bir düzeyini kapsayacak şekilde interdisipliner araştırmaların önemi ve gerekliliği hızla artmaktadır. Tek bir alandaki uzmanın tek başına bir meseleyi ele alması çoğu zaman bağlama uygun olmayan süreç ve sonuçlar doğurmakta bu da verilen hizmetlerin işlevini düşürmektedir (Tanhan, 2019; Tanhan \& Strack, 2020; Tanhan vd., 2020). OSF'nin en fazla vurguladığı noktalardan birisi de araştırmanın başından sonuna kadar olabildiğince farklı ilgili katılımcı ve yetkili kişi, kurum ve kuruluşlarla paydaş olarak araştırmaktır. OSF araştırması sonlandığında da bulguların özellikle de katılımcılardan gönüllü olanlarla yetkili kişi, kurum ve kuruluşlarla interdisipliner ve aktif sosyal savunuculuk perspektifinde paylaşılması araştırmanın çok daha işlevsel olmasını sağlayabilir.

$\mathrm{Bu}$ açıdan aktif savunuculuk alanında, mevcut araştırmanın kolaylaştırıcı ve zorlaştırıcı ana temalarının biyopsikososyal, manevi, politik ve ekonomik platformlarda anlatılması ve ele alınması OSF'nin amacına ulaşması için oldukça gereklidir. Bu aktif sosyal savunuculuk yapılırken, özellikle de en çok talep edilenlerden başlamakla beraber her birinin çok önemli olduğu unutulmamalıdır. Araştırmacıların (Tanhan \& Francisco, 2019; Tanhan vd., 2020) vurguladığı şekilde eğer farklı düzeylerde yer alan kolaylaştırıcı ve zorlaştırıcılar ilgili alandaki uzman kişi, kurum ve kuruluşlarla interdisipliner bir perspektiften senkronize bir şekilde ele alınırsa genel iyilik hâlinin dengeli ve minimum enerjiyle artması çok daha olası olacaktır. Aksi durumda sadece bir düzeydeki (örn., köydeki alt yapı yetersizliği, şehirlerin beton binalarla dolması) ihtiyaçlar giderilir ama/ancak diğerleri (örn., online eğitim, ekonomik ve manevi meseleler) ele alınmazsa çarpık gelişme devam edebilir. Bundan dolayı aktif savunuculuk yapılırken katılımcıların ve araştırmacıların motivasyon ve zaman gibi kaynaklarını optimum düzeyde kullanmak için aktif savunuculuk yapacak her bir temaya veya benzer bazı temalara daha çok ilgi duyan kişilerden birkaç grup kurulabilir.

Bu farklı gruplar mümkünse hem yüz yüze hem de online tüm uygun yollarla yetkili kişi (örn., kurum yöneticileri, bürokratlar, bakanlar, milletvekilleri, belediye başkanları, müdürler), kurum ve kuruluşlara (örn., üniversiteler, milli eğitim ve sağlık bakanlığı, çevre ve şehircilik bakanlığı, Diyanet İşleri Başkanlığı) ulaşıp kolaylaştırıcı ve zorlaştırıcı ana temaları bireysel, mikro, mezo, ekzo ve makrosistemler düzeyinde ele alabilir. Böylece anlamlı ve üretken diyaloglar üretilebilir ve bağlamsal yani EST'nin sonradan eklenen kron sistemsel (zamansal) şartları da düşünülerek genel iyilik hâlinin arttırılması için harekete geçilerek bağlamsal olarak iyi düşünülmüş ve oturtulmuş sistemik dönüşümler oluşturulabilir. Araştırmacı ve hizmet verenlerin interdisipliner ve EST'nin mümkün tüm sistemlerini hareket geçirmek için aktif sosyal savunuculuk yapabilir. Böylece araştırmacılar insanların biyopsikososyal manevi ve ekonomik meselelerini ele alabilir ve genel iyilik hâllerinin birey, mikro, mezo, ekzo, ve makrosistemler düzeyinde işlevsel ve sürdürülebilir bir şekilde yürütülerek daha etkili sonuçlar elde edebilir (Tanhan \& Francisco, 2019; Tanhan \& Strack, 2020). Aksi durumda araştırma yapan ve hizmet verenlerin sistem düzeyinde aktif savunuculuk yapmaması çabaların bireysel düzeyde göreceli olarak küçük etki bırakmasına neden olabilir. Ancak bu bireysel çabaların sürdürülebilir olması çok daha zor olacağı gibi bu meseleler sistemik düzeyde ele alınmadıkça var olan meselelerin ve adaletsizliklerin sistem ve kurumlar düzeyinde daha da normalleşmesine yani derinleşmesine yol açabilir. Bütün bunlar da bu meselelerin bireysel ve sistem düzeyinde ileride ele alınmasını çok daha fazla güçleştirebilir.

Sonuç olarak COVID-19 sürecinde üniversiteli öğrencilerin hayatını kolaylaştıran ve zorlaştıran ana temaların biyopsikososyal manevi ve ekonomik ve EST perspektifinden çok boyutlu 
olduğu ve interdisipliner araştırmalara ihtiyaç duyulduğu görülmektedir. Bu yüzden, araştırma, hizmet verme, eğitim veya aktif savunuculuk alanlarında bağlamsal/sistemik olarak iyi düşünülmüş interdisipliner uygulamaların başta öğrenciler, paydaş kişi, kurum ve kuruluşlar ve son olarak da hâlkın geneli açısından genel iyi oluş hâlini yükselteceği düşünülmektedir.

\section{Sonuç}

Mevcut çalışmanın sonuçları bu araştırmada hedeflenen dört temel amacın tam veya kısmen elde edildiğini göstermektedir: COVID-19 sürecinde üniversiteli öğrencilerin hayatını biyopsikososyal manevi ve ekonomik açıdan (1) 19 kolaylaştıran ve 21 zorlaştıran ana tema kendileri ve diğer paydaşlarla iş birliği yapılarak öğrencilerin biricik perspektifinden OSF kullanılarak belirlenmiştir. (2) Sonuçlar, yani kolaylaştırıcıların ihtiyaç düzeyinde arttırılması ve zorlaştırıcıların çözüme kavuşturulması için gerekenler, katılımcılardan gönüllü olanlarla beraber kısmen yüz yüze ve genellikle de online yollarla ilgili ve yetkili kişi, kurum ve kuruluşlara ulaştırılarak aktif savunuculuk yapılmıştır ve savunuculuk süreci devam etmektedir. (3) Katılımcıların kolaylaştırıcı ve zorlaştırıcı ana temaları EST'nin hangi sistemlerine atfettiği ele alınarak bu atfetmenin ana tema ve hikâyelerle paralellik gösterdiği ve Türkiye bağlamında anlamlı olduğu bulunmuştur. (4) Son olarak, OSF'nin orijinaline uygun olarak Türkçeye uyarlandığı görülmektedir. Ayrıca OSF'yi geliştiren Tanhan ve Strack (2020)'in önerdiği beşinci basamak da oldukça etkili bir şekilde bu adapte edilmiş Türkçe OSF versiyona eklenerek COVID-19 gibi zorlu bir süreçte oldukça etkili bir şekilde kullanılmıştır. Sonuç olarak EST bağlamında TeTKA kuramsal çerçevesi içerisinde uygulanan mevcut OSF araştırmasının biyopsikososyal manevi ve ekonomik bütüncül bir perspektiften dört temalı alan olan araştırma, hizmet verme, eğitim ve aktif savunuculuk alanlarında da spesifik uygulama önerileri sunularak literatüre özgün bir değer katmıştır.

\section{Teşekkür ve Çalışmayı İthaf Etmek:}

Bu makaleyi ilk olarak COVID-19 pandemisi dolayısıyla hayatını kaybedenlere, bu kişilerin akrabalarına ve pandemiden dolayı ciddi düzeyde ve uzun süreli biyopsikososyal ekonomik ve manevi sorunlarla karşılaşan insanlık kabilesinin tüm bireylerine ithaf ediyorum. Daha sonra bu çalışmayı 2019-2020 Bahar Döneminde değer verdiği şekilde mezuniyet töreni yap(a)madan mezun olan veya pandemi dolayısıyla dönem uzatan dünyadaki tüm üniversiteli öğrencilerimize acizane atfediyorum. Daha da özelde, bu çalışmayı, Türkiye'nin doğusunda yer alan ve bu bahar döneminde mezun olan veya ol(a)mayan tüm öğrencilerimize acizane atfediyorum. Bölgede psikolojik danışmanlık hizmetlerine olan talebin bir kısmını kendi kapasitesine göre karşılayan ve COVID-19 pandemi sürecinde gerektiğinde fiziki ve genelde online olarak ruh sağlığı hizmetlerinin en güzel şekilde yürümesi için çaba sarf eden Adıyaman Üniversitesi (ADYÜ) PDR ABD son sinıf ögrencileri ve klinikte işleyişin fiziki ve online ortamda aksamadan işlemesi için çaba gösteren tüm $P D R A B D$ ögrencilerine tüm emekleri için bu çalışmayı kendilerine özellikle atfediyorum.

Makalenin araştırma kısmında ve özellikle de son kontrollerinin yapılmasında kritik ve anlamlı geribildirimleriyle çalışmaya manalı bir değer katan saygıdeğer hocalarım/meslektaşlarım İbrahim Doyumğaç, Emel Genç, İnci Yilmazli Trout, Cihat Çelik, Büşra Ünverdi, Ayşegül Özsolak, Mehmet Şirin Akça, Ebru Talibe Görünmek, Sümeyye Özer, İlhan Çiçek, Mustafa Ercengiz, Ramazan Demir, Melih Sever ve Mustafa Said Kıymaz'a en kalbi teşekkürlerimi sunuyorum. Ayrıca psikolojik danışmanlık (klinik) çalışmalarımızda sürekli destek veren Uzman Psikiyatrist Ahmet Nalbant ve Uzman Psikolog Cihat Çelik ve Ali Kuştepe hocalarıma da çok teşekkür ediyorum. Araştırma sürecinde katılımcılara ulaşma ve analiz sürecinde paydaş olarak çalışmaya değer katan ve bu çalışma için araştırma asistanlığı yapan Azime İpek, Medine Demir, Yeter Kaçmaz, Fatma Erdinç'e ve hem psikolojik danışmanlık hizmetleri ve araştırmalarında hem de klinik asistanlığımı yapan PDR dördüncü sınıf öğrencileri Sultan Bakırcı, Sevda Sevim, Merve Demirel, Ahmet Tamir, Sevgi Önder, Medine Akgün ve İsmail Hakkı Ateş’e ve PDR üçüncü sınıf öğrencileri Cansu Çalışır, Abdulsamet Satkan ve Tuğçe Uçar'a tüm çabaları ve geribildirimleri için kalpten teşekkür ediyorum. 
Bu destekler olmasaydı bu çalışmanın yapılması ve yürütülmesi imkânsız ya da çok daha az etkili olurdu. Bu zorlu pandemi sürecinde ve sonrasında, bu çalışmanın insanlık için daha adil, anlamlı ve yaşanabilir bir dünya ve medeniyete değer katması acizane dileğiyle.

\section{Kaynakça}

Açıköz, Ö., \& Günay, A. (2020). They early impact of the Covid-19 pandemic on the global andTurkish economy. Turkish journal of medical sciences, 50 (SI-1), 520-526. https://doi.org/10.3906/sag-2004-6 PMID: 32283904

Afacan, E., \& Avc1, N. (2020). Koronavirüs (COVID-19) örneği üzerinden salgın hastalıklara sosyolojik bir bakış. Avrasya Sosyal ve Ekonomi Araştırmaları Dergisi, 7(5), 1-14. https://dergipark.org.tr/en/pub/asead/issue/54658/738133

Akar, A., \& Aktan, T. (2020). Psikolojik Sağlamlik Tutum Beceri Ölçeğinin (PTSBÖ) uyarlamasi: Geçerlik güvenirlik çalışması. Elektronik Sosyal Bilimler Dergisi, 19(74), 665-679.DOI: 10.17755/esosder.574101

Akca, M. (2020). COVID-19'un havac1lık sektörüne etkisi. Avrasya Sosyal ve Ekonomi Araştırmalart Dergisi, 7(4), 45-64. https://dergipark.org.tr/en/pub/asead/issue/54055/723434

Akın, A., Akça, M. Ş., \& Gülşen, M. (2015). Turkish version of the distress tolerance scale: A study of validity and reliability. Kastamonu Education Journal, 23(2), 619-630.

Akkurt, M. N., Ng, K. M., \& Kolbert, J. (2018). Multicultural discussion as a moderator of counseling supervision-related constructs. International Journal for the Advancement of Counselling, 4O(4), 455-468. https://doi.org/10.1007/s10447-018-9337-z

Aksoy, Ş., \& Mamatoğlu, N. (2020). COVID-19 salgın döneminde örgütlerde güvenlik ikliminin iş güvenliği uzmanları perspektifinden değerlendirilmesi. Avrasya Sosyal ve Ekonomi Araştırmaları Dergisi,

$7(5)$

26-37. https://dergipark.org.tr/en/pub/asead/issue/54658/737045

Akyol, G., Başkan, A. H., \& Başkan, A. H. (2020). Yeni tip koronavirüs (Covid-19) döneminde spor bilimleri fakültesi öğrencilerinin karantina zamanlarinda yaptiklari etkinlikler ve sedanter bireylere önerileri. Avrasya Sosyal ve Ekonomi Araştırmaları Dergisi, 7(5), 190-203.

Aldemir, C., \& Avşar, M. (2020). Pandemi döneminde dijital vatandaşlık uygulamaları. Avrasya Sosyal ve Ekonomi Araştırmalart Dergisi, 7(5), 148-169. https://dergipark.org.tr/en/pub/asead/issue/54658/738205

Alsandor, D. J., \& Yilmazli Trout, I. (2020). Graduate student well-being: Learning and living during the COVID-19 pandemic. Multidisciplinary Perspectives in Higher Education.

Arslan, G., \& Tanhan, A. (2019). Ergenlerde okul aidiyeti, okul işlevleri ve psikolojik uyum arasındaki ilişkinin incelenmesi [examining the association between school belonging, school functioning, and psychological adjustment in adolescents]. Journal of Education for Life, 33(2), 318-332. https://doi.org/10.33308/26674874.2019332127.

Arslan, Ü., \& Sommers-Flanagan, J. (2018). The new stage of the Turkish counseling system: Explosive growth (2000 to the present). Journal of Multicultural Counseling and Development, 46(2), 115-128. https://doi.org/10.1002/jmcd.12096

Arslan, G., Yıldırım, M., Tanhan, A., Buluş, M., \& Allen, K. A. (2020). Coronavirus stress, optimism-pessimism, psychological inflexibility, and psychological health: Psychometric 
properties of the coronavirus stress measure. International Journal of Mental Health and Addiction. https://doi.org/10.1007/s11469-020-00337-6

Avci, A. (2020a). Egitim bilisim agi (Eba) sisteminde yer alan muzik egitimi derslerine yonelik ogretmen gorusleri. Akdeniz Egitim Arastirmalari Dergisi, 14(32), 328-353. doi: 10.29329/mjer.2020.258.17

Avci, A. (2020b). Dijital okuryazarlıkta müzik eğitimi. AKRA Kültür Sanat ve Edebiyat Dergisi, 8(20), 111-131. 10.31126/akrajournal.650884

Balcığlu, İ., \& Balcıŏlu, Y. H. (2018). Elektrokonvülzif terapi ile ilgili Türkiye'deki ve dünyadaki yasal uygulamalar ve sorunlar. Turkiye Klinikleri J Psychiatry-Special Topics, 11(1), 80-4.

Bao, Y., Sun, Y., Meng, S., Shi, J., \& Lu, L. (2020). 2019-nCoV epidemic: Address mental health care to empower society. The Lancet, 395(10224), e37-e38. https://doi.org/10.1016/S01406736(20)30309-3

Becker, S.P., Langberg, J.M. \& Byars, K. C. (2015). Advancing a biopsychosocial and contextual model of sleep in adolescence: A review and introduction to the special issue. $J$ Youth Adolescence, 44, 239-270. https://doi.org/10.1007/s10964-014-0248-y

Belen, H. \& Yıldırım, M. (2020). Psychometric analysis of inflexibility of happiness in undergraduate students: A reliability and validity study. Journal of Positive School Psychology, 4(1), 69-78. http://journalppw.com/index.php/JPPW/article/view/211

Borasio, G. D., Gamondi, C., Obrist, M., \& Jox, R. (2020). COVID-19: Decision making and palliative care. Swiss Medical Weekly, 150(1314). https://doi.org/10.4414/smw.2020.20233

Bostan S, Erdem R, Öztürk YE, Kılıç T, \& Yılmaz A (2020). The effect of COVID-19 pandemic on the Turkish society. Electronic Journal of General Medicine, 17(6), em237. https://doi.org/10.29333/ejgm/7944

Bronfenbrenner, U. (1977). Toward an experimental ecology of human development. American Psychologist, 32(7), 513-531. doi:10.1037/0003-066X.32.7.513

Bronfenbrenner, U. (1979). The ecology of human development. Harvard university press.

Bronfenbrenner, U., \& Evans, G. W. (2000). Developmental science in the 21st century: Emerging questions, theoretical models, research designs and empirical findings. Social Development, 9(1), 115-125. https://dx.doi.org/10.1111/1467-9507.00114

Brunsden, V., \& Goatcher, J. (2007). Reconfiguring photovoice for psychological research. The Irish Journal of Psychology, 28(1-2), 43-52.https://doi.org/10.1080/03033910.2007.10446247

Bulut, S. (2010). Bibloterapi yönteminin okullarda psikolojik danışmanlar ve öğretmenler tarafindan kullanılması. Elektronik Sosyal Bilimler Dergisi, 9(34), 17-31.

Büyükşahin Çevik, G., Doğan, İ., \& Yildiz, M. A. (2016). Pedagojik formasyon eğitimi alan ögrencilerin y1lmazlık ve tükenmişliklerinin incelenmesi. Mersin University Journal of the Faculty of Education, 12(3). http://dx.doi.org/10.17860/mersinefd.282395

Cao, W., Fang, Z., Hou, G., Han, M., Xu, X., Dong, J., \& Zheng, J. (2020). The psychological impact of the COVID-19 epidemic on college students in China. Psychiatry Research, 112934. https://doi.org/10.1016/j.psychres.2020.112934

Çevirme, A., \& Kurt, A. (2020). COVID-19 pandemisi ve hemşirelik mesleğine yansımaları. Avrasya Sosyal ve Ekonomi Araştırmalarl Dergisi, 7(5), 46-52. https://dergipark.org.tr/en/pub/asead/issue/54658/723821 
Chen, Q., Liang, M., Li, Y., Guo, J., Fei, D., Wang, L., He, L., Sheng, C., Cai, Y, Li, X., Wang, J., \& Zhang, Z. (2020). Mental health care for medical staff in China during the COVID-19 outbreak. The Lancet Psychiatry, 7(4), e15-e16. https://doi.org/10.1016/S22150366(20)30078-X

Christensen, M. C., Yilmazli Trout, I., \& Perez, B. (2018). Using participatory action research to teach community practice in a post-truth era. Acta Paedagogica Vilnensia, 41. https://doi.org/10.15388/ActPaed.41.12372

Cortese, S., Asherson, P., Sonuga-Barke, E., Banaschewski, T., Brandeis, D., Buitelaar, J., ... \& Doepfner, M. (2020). ADHD management during the COVID-19 pandemic: Guidance from the European ADHD Guidelines Group. The Lancet Child \& Adolescent Health. https://doi.org/10.1016/S2352-4642(20)30110-3

Çaykuş, E. T., \& Çaykuş, T. M. (2020). COVID-19 pandemi sürecinde çocukların psikolojik dayanıklılığını güçlendirme yolları: Ailelere, öğretmenlere ve ruh sağlı̆̆ı uzmanlarına öneriler. Avrasya Sosyal ve Ekonomi Araştırmaları Dergisi, 7(5), 95-113.

Çetin, C., \& Anuk, Ö. (2020). COVID-19 pandemi sürecinde yalnizlik ve psikolojik dayaniklilik: Bir kamu üniversitesi öğrencileri örneklemi. Avrasya Sosyal ve Ekonomi Araştırmaları Dergisi, 7(5), 170-189.

Çiçek, I., Tanhan, A., Arslan, G., \& Bulus, M. (manuscript under review). Psychological inflexibility predicts depression and anxiety during COVID-19: Acceptance and commitment therapy perspective.

Çitak, Ş., \& Pekdemir, Ü. (2020). An analysis on sleep habits and generalized anxiety levels of individuals during the COVID-19 pandemic. Journal of Family Counseling and Education, 5(1), 60-73. doi:10.32568/jfce.742086

Delgado, H., \& Wester, K. (2020). Using photovoice to promote meaning-making in a suicide loss support group. Journal of Mental Health Counseling, 42(3), 189-205. https://doi.org/10.17744/mehc.42.3.01

Demir Öztürk, E., Kuru, G., \& Demir Yıldız, C. (2020). COVID-19 pandemi günlerinde anneler ne düşünür çocuklar ne ister? Anner ve çocuklarının pandemi algısı. Avrasya Sosyal ve Ekonomi Araştırmaları Dergisi, 7(5), 204-220. https://dergipark.org.tr/en/pub/asead/issue/54658/733406

Demir, R. \& Türk, F. (2020). Pozitif psikoloji: Tarihçe, temel kavramlar, terapötik süreç, eleştiriler ve katk1lar. Humanistic Perspective, 2(2), 108-125. https://dergipark.org.tr/en/pub/hp/issue/54982/727363

Demir Yildiz, C., \& Dönmez, B. (2017). Ekolojik sistemler kurami çerçevesinde yöneticilerin karar verme davranişini etkileyen faktörlerin incelenmesi. Electronic Turkish Studies, 12(28). http://dx.doi.org/10.7827/TurkishStudies.12328

Dollarhide, C. T., Clevenger, A., Dogan, S., \& Edwards, K. (2016). Social justice identity: A phenomenological study. Journal of Humanistic Psychology, 56(6), 624-645. https://doi.org/10.1177/0022167816653639

Dost, B., Koksal, E., Terzi, Ö., Bilgin, S., Ustun Y. B., \& Arslan, H. N. (2020). Attitudes of anaesthesiology specialists and residents toward patients infected with the novel coronavirus (COVID-19): A national survey study. Surgical Infections, 21(4), 350-356. https://doi.org/10.1089/sur.2020.097 
Doyumğaç, İ., Tanhan, A., \& Kıymaz, M. S., (2020). Understanding the most important facilitators and barriers for online education during COVID-19 through online photovoice methodology. Manuscript in preparation.

Dushıme, C., \& Hashemıpour, S. (2020). The psychological effect of the COVID-19 pandemic in Turkey and the world at the context of political psychology. Avrasya Sosyal ve Ekonomi Araştırmalarl Dergisi, $7(6)$, https://dergipark.org.tr/en/pub/asead/issue/55211/749653

Dünya Sağlık Örgütü [World Health Organization]. (2020, Nisan 20). Naming the coronavirus disease (COVID-19) and the virus that causes it.

Ercengiz, M., Kurt, S. K., \& Polat, S. (2014). Öğretmen adaylarının çevre sorunlarina yönelik duyarliliklarinin incelenmesi. (Ağri ili örneği). Ekev Akademi Dergisi, 18(59), 119-132.

Erdem, Ö., \& Bucaktepe, P. G. E. (2012). Postpartum depresyon görülme sıklı̆̆1 ve tarama yöntemleri. Dicle Tip Dergisi, 39(3), 458-461.doi: 10.5798/diclemedj.0921.2012.03.0182

Ermis-Demirtas, H., Watson, J. C., Karaman, M. A., Freeman, P., Kumaran, A., Haktanir, A., \& Streeter, A. M. (2018). Psychometric properties of the multidimensional scale of perceived social support within Hispanic college students. Hispanic Journal of Behavioral Sciences, 40(4), 472-485. https://doi.org/10.1177/0739986318790733

Genç, E., Turhan, Z., \& Tanhan, A. (2020a). Koronavirüs salgın sürecinde ve afet dönemlerinde psikolojik destek hizmetleri: Aile odaklı psikolojik müdahale programı geliştirme [Psychological support service during Covid-19 pandemic and disasters: Developing a family-based psychological intervention program]. Manuscript under review.

Genç, E., Su, Y., \& Turhan, Z. (2020b). The mediating role of dyadic coping on the effects of Covid19 and relationship satisfaction. Manuscript under review.

Gençalp, D. K. (2020). COVID-19 salgını döneminde ilk ve acil yardım öğrencilerinin beslenme alışkanlıkları ve fiziksel aktivite durumlarının değerlendirilmesi evaluation of dietary habits and physical activity status of first and emergency aid students in covid-19 outbreak period. Paramedik ve Acil Sağllk Hizmetleri Dergisi, 1(1), 1-15.

Goodhart, F. W., Hsu, J., Baek, J. H., Coleman, A. L., Maresca, F. M., \& Miller, M. B. (2006). A view through a different lens: Photovoice as a tool for student advocacy. Journal of American College Health, 55(1), 53-56. https://doi.org/10.3200/JACH.55.1.53-56

González-Sanguino, C., Ausín, B., ÁngelCastellanos, M., Saiz, J., López-Gómez, A., Ugidos, C., \& Muñoz, M. (2020). Mental health consequences during the initial stage of the 2020 Coronavirus pandemic (COVID-19) in Spain. Brain, Behavior, and Immunity. https://doi.org/10.1016/j.bbi.2020.05.040

Göze Kaya, D. (2020). Koronavirüs pandemisinin küresel ekonomideki izleri: Kamu finansal dengesi, ticaret hacmi, enflasyon, işsizlik ve ekonomik büyüme. Avrasya Sosyal ve Ekonomi Araştırmaları Dergisi, 7(5), 221-237. https://dergipark.org.tr/en/pub/asead/issue/54658/738539

Gumusgul, O., \& Aydoğan, R. (2020). Yeni tip koronavirüs-covid 19 kaynaklı evde geçirilen boş zamanların ev içi rekreatif oyunlar ile değerlendirilmesi. Spor Eğitim Dergisi, 4(1), 107-114.

Güler, H. (2020). Koronavirüsü (COVID-19) Günlerinde bankalara iletilen müşteri itiraz ve şikayetlerin incelenmesi. Avrasya Sosyal ve Ekonomi Araştırmaları Dergisi, 7(4), 85-99. Retrieved from https://dergipark.org.tr/en/pub/asead/issue/54055/716811 
Güreşçi, M. (2020). COVID-19 salgınında Türkiye'de kriz yönetimi iletişimi: T.C. Sağlık Bakanlığı. Avrasya Sosyal ve Ekonomi Araştırmalart Dergisi, 7(5), 53-65. https://dergipark.org.tr/en/pub/asead/issue/54658/739496

Güven, H. (2020). COVID-19 pandemik krizi sürecinde e-ticarette meydana gelen değişimler. Avrasya Sosyal ve Ekonomi Araştırmaları Dergisi, 7(5), 251-268. https://dergipark.org.tr/en/pub/asead/issue/54658/735825

Haktanir, A., Lenz, A. S., Can, N., \& Watson, J. C. (2016). Development and evaluation of Turkish language versions of three positive psychology assessments. International Journal for the Advancement of Counselling, 38(4), 286-297. https://doi.org/10.1007/s10447-016-9272-9

Haktanir, A., Seki, T., \& Dilmaç, B. (2020). Adaptation and evaluation of Turkish version of the fear of COVID-19 scale. Death Studies, 1-9.https://doi.org/10.1080/07481187.2020.1773026

Halaçl1, B., Kaya, A., \& Topeli, A. (2020). Critically-ill COVID-19 patient. Turkish Journal of Medical Sciences, 50. doi:10.3906/sag-2004-122

Hasöksüz, M., Kiliç, S., \& Saraç, F. (2020). Coronaviruses and SARS-CoV-2. Turkish Journal of Medical Sciences, 50. doi:10.3906/sag-2004-127

Huang, C., Wang, Y., Li, X., Ren, L., Zhao, J., Hu, Y., Zhang, L., Fan, G., Xu, J, Gu, X., Cheng, Z., Yu, T., Xia, J., Wei, Y., Wu, W., Xie, X., Yin, W., Li, H., Liu, ... \& Cao, B (2020). Clinical features of patients infected with 2019 novel coronavirus in Wuhan, China. The Lancet, 395(10223), 497-506. https://doi.org/10.1016/S0140-6736(20)30183-5

İkiz, E., İkiz, D., Asıcı,, A., Savc1., A, \& Yörük, A. (2015). Problemli internet kullanımı ile üniversite yaşamına uyum ilişkisi. Bartın University Journal of Faculty of Education, 4(1), 34-50. https://dergipark.org.tr/en/pub/buefad/issue/3816/51218

Kağnıc1, D. Y. (2012). The role of multicultural personality in predicting university adjustment of international students in Turkey. International Journal for the Advancement of Counselling, 34(2), 174-184. doi:10.1007/s10447-012-9149-5

Kalkan, B. (2020). Integrating technology in counselor education programs. Kastamonu Eğitim Dergisi, 28(3), 1181-1189. Doi DOI: 10.24106/kefdergi.3662

Kalkan, B., \& Can, N. (2019). Supervision in counselor education: Exploration of current status and standards in Turkey. Adlyaman Üniversitesi Eğitim Bilimleri Dergisi, 9(2), 271-290. http://dx.doi.org/10.17984/adyuebd

Kara, E. (2020). COVID-19 pandemisi: İşücü üzerindeki etkileri ve istihdam tedbirleri. Avrasya Sosyal ve Ekonomi Araştırmalarl Dergisi, 7(5), 269-282. https://dergipark.org.tr/en/pub/asead/issue/54658/738164

Karaman, M. A., \& Watson, J. C. (2017). Examining associations among achievement motivation, locus of control, academic stress, and life satisfaction: A comparison of US and international undergraduate students. Personality and Individual Differences, 111, 106-110. https://doi.org/10.1016/j.paid.2017.02.006

Karataş, Z. (2020). COVID-19 Pandemisinin toplumsal etkileri, değişim ve güçlenme. Türkiye Sosyal Hizmet Araştırmaları Dergisi, 4(1), 3-17.

Kart, D. (2020). COVID-19 salgın sürecinde Türkiye'de devlet tiyatrolarının sosyal medya kullanımının online itibar ile ilişkilendirilmesi. Avrasya Sosyal ve Ekonomi Araştırmaları Dergisi, 7(6), 400-421. https://dergipark.org.tr/en/pub/asead/issue/55211/750625 
Kırmızıgül, H. (2020). COVID-19 salgını ve beraberinde getirdiği eğitim süreci. Avrasya Sosyal ve $\begin{array}{lllll}\text { Ekonomi Araştırmalarl } & \text { Dergisi, } & 7 & \text { (5), } & \text { 283-289. }\end{array}$ https://dergipark.org.tr/en/pub/asead/issue/54658/725274

Kızıldağ, S., Zorbaz, S. D., Gençtanırım, D., \& Arıcı, F. (2012). Hacettepe üniversitesi öğrencilerinin psikolojik danışma yardımı almaya ve bu yardımın sunulduğu birimlere ilişkin görüşleri. Mersin Üniversitesi Ĕ̆itim Fakültesi Dergisi, 8(3), 185-196.

Kirman, F. (2020). Sosyal medyada salgin psikolojisi: alg1, etki ve başa çıkma. Dünya İnsan Bilimleri Dergisi, 2020(2), 11-44.

Korkmaz, A. (2020). COVID-19'un işçiler üzerindeki etkileri ve bir dizi çözüm önerileri. Avrasya Sosyal ve Ekonomi Araştırmalart Dergisi, 7(5), 114-132. https://dergipark.org.tr/en/pub/asead/issue/54658/737770

Krafft, J., Haeger, J. A., \& Levin, M. E. (2019). Comparing cognitive fusion and cognitive reappraisal as predictors of college student mental health. Cognitive Behaviour Therapy, 48(3), 241-252. https://doi.org/10.1080/16506073.2018.1513556

Kürtüncü, M., \& Kurt, A. (2020). COVID-19 pandemisi döneminde hemşirelik öğrencilerinin uzaktan eğitim konusunda yaşadiklari sorunlar. Avrasya Sosyal ve Ekonomi Araştırmaları Dergisi, 7(5), 66-77.

Liu, S., Yang, L., Zhang, C., Xiang, Y. T., Liu, Z., Hu, S., \& Zhang, B. (2020). Online mental health services in China during the COVID-19 outbreak. The Lancet Psychiatry, 7(4), e17-e18. https://doi.org/10.1016/S2215-0366(20)30077-8

Macit, A., \& Macit, D. (2020). Türk havacılık sektöründe COVID-19 pandemisinin yönetimi. Avrasya Sosyal ve Ekonomi Araştırmalart Dergisi, 7(4), 100-116. https://dergipark.org.tr/en/pub/asead/issue/54055/717678

Maiter, S., Simich, L., Jacobson, N., \& Wise, J. (2008). Reciprocity: An ethic for community-based participatory action research. Action Research, 6(3), 305325. https://doi.org/10.1177/1476750307083720

Mamun, M. A., \& Griffiths, M. D. (2020). First COVID-19 suicide case in Bangladesh due to fear of COVID-19 and xenophobia: possible suicide prevention strategies. Asian Journal of Psychiatry, 51, 102073. https://doi.org/10.1016/j.ajp.2020.102073

Mills K. (Host). (2020-present). The role of resilience in the face of COVID-19 [Audio podcast]. Speaking of psychology. http://sopapa.apa.libsynpro.com/the-role-of-resilience-in-the-faceof-covid-19-with-ann-masten-phd

Minkler, M. (2000). Using participatory action research to build healthy communities. Public Health Reports, 115(2-3), 191. doi:10.1093/phr/115.2.191

Nesipoğlu, G. (2017). Zorunlu yatış özelinden ulusal "ruh sağlığı yasası"nın önemi ve gerekliliği. Türkiye Klinikleri Tip Etiği-Hukuku-Tarihi Dergisi, 25(2), 49-56. doi: 10.5336/mdethic.2017-56263

Otanga, H., Musili, P. M., Tanhan, A., Buluş, M., \& Arslan, G. (2020). Exploring college students' biopsychosocial spiritual wellbeing and problems during COVID-19 through a contextual and comprehensive framework. Manuscript under review.

Özkaral, T. C., \& Bozyiğit, R. (2020). Coğrafya ve sosyal bilgiler öğretmen adaylarinin "çarpık kentleşme" kavramina yönelik metaforik algilari. Avrasya Sosyal ve Ekonomi Araştırmaları Dergisi, 7(5), 389-405. 
Özkoçak, V., Koç, F., \& Gültekin, T. (2020). Pandemilere Antropolojik Bakış: Koronavirüs (Covid19) Örneği. Electronic Turkish Studies, 15(2). https://dx.doi.org/10.29228/TurkishStudies.

Özyürek, R. (2019). Psikolojik danışman eğitimi ve mesleğin profesyonel kimlik gelişimi için gereksinim duyulan yasa ve yönetmelik düzenlemeleri. Turkish Psychological Counseling and Guidance Journal, 9(54). http://www.turkpdrdergisi.com/index.php/pdr/article/view/770

Petersen, E., \& Gökengin, D. (2020). SARS-CoV-2 epidemiology and control, different scenarios for Turkey. Turkish Journal of Medical Sciences. doi:10.3906/sag-2003-260

Rose, S. (2020). Medical student education in the time of COVID-19. JAMA, 323(21), 2131-2132. doi:10.1001/jama.2020.5227

Samur, S. (2020). COVID-19 pandemi sürecinde Ankara'daki devlet üniversitelerinin Instagram kullanımları üzerine nicel bir araştırma. Avrasya Sosyal ve Ekonomi Araştırmaları Dergisi, 7(6), 436-457. https://dergipark.org.tr/en/pub/asead/issue/55211/752477

Sarıçam, H., Erguvan, F. M., Akın, A., \& Akça, M. Ş. (2014). The Turkish short version of the Intolerance of Uncertainty (IUS-12) Scale: The study of validity and reliability. Route Educational and Social Science Journal, 1(3), 148-157.

Sarıtaş, E., \& Barutçu, S. (2020). Öğretimde dijital dönüşüm ve öğrencilerin çevrimiçi öğrenmeye hazır bulunuşluğu: Pandemi döneminde Pamukkale Üniversitesi öğrencileri üzerinde bir araştırma. Internet Uygulamaları ve Yönetimi Dergisi, 11(1), 5-22.

Satici, B., Gocet-Tekin, E., Deniz, M. E., \& Satici, S. A. (2020). Adaptation of the Fear of COVID19 Scale: Its association with psychological distress and life satisfaction in Turkey. International Journal of Mental Health and Addiction. https://doi.org/10.1007/s11469-020-00294-0

Sever, M., \& Özdemir, S. (2020). Görünmezi görünür kılma! Koronavirüs (COVID-19) sürecinde sosyal hizmet öğrencisi olma deneyimi: Bir fotoses (photovoice) çalışması. Manuscript under review.

Smith, J. A., \& Osborn,M. (2003). Interpretative phenomenological analysis. In J. A. Smith (Ed.), Qualitative psychology: A practical guide to methods (pp. 51-80). London: Sage.

Soylu, Ö. (2020). Türkiye ekonomisinde COVID-19'un sektörel etkileri. Avrasya Sosyal ve Ekonomi $\begin{array}{lll}\text { Araştırmalarl } & \text { Dergisi, } & \text { 169-185. }\end{array}$ https://dergipark.org.tr/en/pub/asead/issue/55211/750273

Soysal, G. (2020). Koronavirüs salgını ve yaşl1lık. Avrasya Sosyal ve Ekonomi Araştırmaları Dergisi, 7(5), 290-301. https://dergipark.org.tr/en/pub/asead/issue/54658/736807

Şenol, Z., \& Zeren, F. (2020). Coronavirus (COVID-19) and stock markets: The effects of the pandemic on the global economy. Avrasya Sosyal ve Ekonomi Araştırmaları Dergisi, 7(4), 1-16. https://dergipark.org.tr/en/pub/asead/issue/54055/721871

Tanhan, A. (2018). Beginning counsellors' supervision in counseling and challenges and supports they experience: Based on developmental models. Adiyaman Üniversitesi Eğitim Bilimleri Dergisi, 8(1), 49-71. https://doi.org/10.17984/adyuebd.336222

Tanhan, A. (2019). Acceptance and commitment therapy with ecological systems theory: Addressing Muslim mental health issues and wellbeing. Journal of Positive Psychology and Wellbeing, 3(2), 197-219. http://journalppw.com/index.php/JPPW/article/view/172 
Tanhan, A., \& Francisco, V. T. (2019). Muslims and mental health concerns: A social ecological model perspective. Journal of Community Psychology, 47(4), 964-978. https://doi.org/10.1002/jcop.22166

Tanhan, A., \& Strack, R. W. (2020). Online photovoice to explore and advocate for Muslim biopsychosocial spiritual wellbeing and issues: Ecological systems theory and ally development. Current Psychology, 1-16. https://doi.org/10.1007/s12144-020-00692-6

Tanhan, A., Yavuz K. F., Young, J. S., Nalbant, A., Arslan, G., Yıldırım, M., Ulusoy, S., Genç, E., Uğur, E., \& Çiçek, İ. (2020). A proposed framework based on literature review of online contextual mental health services to enhance wellbeing and address psychopathology during COVID-19. Electronic Journal of General Medicine, 17(6), em254. https://doi.org/10.29333/ejgm/8316.

Tombul, T., Anlar, Ö., Sayın, R., Beşiroğlu, L., \& Dizkırıcı, A. (2005). Geç başlangıçlı ve atipik seyirli bir SSPE olgusu. Van Tip Dergisi, 12(4), 248-51.

Topuz, E. (2020). Sömürgeciliğe ve salgın hastalığa 40 gün mola mı? Yoksa sistemin istikrarına bir katk1 mı? Usul-i Karantina. Avrasya Sosyal ve Ekonomi Araştırmaları Dergisi, 7(5), 238250. https://dergipark.org.tr/en/pub/asead/issue/54658/737637

Torun Kayabaş1, E. (2020). COVID-19'un piyasalara ve tüketici davranışlara etkisi. Avrasya Sosyal ve Ekonomi Araştırmalarl Dergisi, $\quad 7(5), \quad$ 15-25. https://dergipark.org.tr/en/pub/asead/issue/54658/740424

Tuncay, F. E., Koyuncu, E., \& Özel, Ş. (2020). Pandemilerde sağlık çalışanlarının psikososyal sağlığını etkileyen koruyucu ve risk faktörlerine ilişkin bir derleme. Ankara Medical Journal, (2), 488-501. doi:10.5505/amj.2020.02418

Uğur, E., Kaya, Ç., \& Tanhan, A. (2020). Psychological inflexibility mediates the relationship between fear of negative evaluation and psychological vulnerability. Current Psychology.

Uygun, M. (2011). Tüketici araştırmalarında nitel bir araştırma yöntemi olarak fotoğrafa dayalı öykülemenin kullanımı. Tüketici ve Tüketim Araştırmaları Dergisi, 3(1), 29-64.

Viner, R. M., Russell, S. J., Croker, H., Packer, J., Ward, J., Stansfield, C., ... \& Booy, R. (2020). School closure and management practices during coronavirus outbreaks including COVID19: a rapid systematic review. The Lancet Child \& Adolescent Health. https://doi.org/10.1016/S2352-4642(20)30095-X

Viskovich, S., \& Pakenham, K. I. (2020). Randomized controlled trial of a web-based Acceptance and Commitment Therapy (ACT) program to promote mental health in university students. Journal of Clinical Psychology, 76(6), 929-951. https://doi.org/10.1002/jclp.22848

Wang, C., \& Burris, M. A. (1997). Photovoice: Concept, methodology, and use for participatory needs assessment. Health Education \& Behavior, 24(3), 369-387.

Wang, C., Cheng, Z., Yue, X.-G., \& McAleer, M. (2020). Risk Management of COVID-19 by universities in China. Journal of Risk and Financial Management, 13(2), 36. http://doi.org/10.3390/jrfm13020036

Warne, M., Snyder, K., \& Gillander Gådin, K. (2013). Photovoice: an opportunity and challenge for students' genuine participation. Health Promotion International, 28(3), 299-310. https://doi.org/10.1093/heapro/das011

Yakar, B., Kaygusuz, T. Ö., Pirinçci, E., Önalan, E., \& Ertekin, Y. H. (2020). Knowledge, attitude and anxiety of medical students about the current COVID-19 outbreak in Turkey. Family Practice and Palliative Care, 5(2), 36-44. https://doi.org/10.22391/fppc.737469 
Yao, H., Chen, J. H., \& Xu, Y. F. (2020). Rethinking online mental health services in China during the COVID-19 epidemic. Asian Journal of Psychiatry, 50, 102015. https://doi.org/10.1016/j.ajp.2020.102015 PMID: 32247261

Yavuz, K. F., Türkçapar, M. H., Demirel, B., \& Karadere, E. (2011). Adaptation, validity and reliability of the Leahy Emotional Schema Scale Turkish version based on Turkish university students and workers. Dusunen Adam The Journal of Psychiatry and Neurological Sciences, 24(4), 273. https://dx.doi.org/10.5350/DAJPN2011240403

Yilmazli Trout, I., Perez, B., \& Christensen, M. C. (2019). Connecting classroom to community through photovoice: Pedagogical implications. LEARNing Landscapes, 12(1), 285-301. https://eric.ed.gov/?id=EJ1245299

Zeybekoğlu Akbaş, Ö., \& Dursun, C. (2020). Koronavirüs (COVID-19) pandemisi sürecinde özel alanına kamusal alanı sığdıran çalışan anneler. Avrasya Sosyal ve Ekonomi Araştırmaları Dergisi, 7(5), 78-94. https://dergipark.org.tr/en/pub/asead/issue/54658/738006 